Changes in Stratigraphic Nomenclature by the U.S. Geological Survey, 1975

GEOLOGICAL SURVEY BULLETIN 1422-A

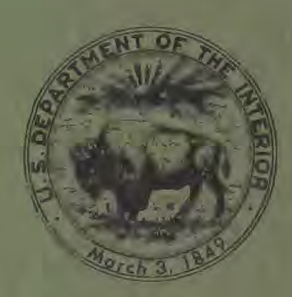





\section{Changes in Stratigraphic}

Nomenclature by the U.S.

\section{Geological Survey, 1975}

By GEORGE V. COHEE and WILNA B. WRIGHT

CONTR I B U T I ONS TO STRATIGRA PHY

GEOLOGICA L S URVEY B ULLETIN 1422-A

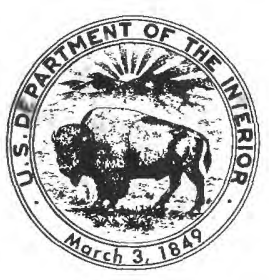




\section{UNITED STATES DEPARTMENT OF THE INTERIOR}

THOMAS S. KLEPPE, Secretary

\section{GEOLOGICAL SURVEY}

V. E. McKelvey, Director

Library of Congress Cataloging in Publication Data

Cohee, George Vincent, 1907-

Changes in stratigraphic nomenclature by the U.S. Geological Survey, 1975. (Contributions to Stratigraphy)

(Geological Survey Bulletin 1422-A)

Bibliography: p. A74-A84.

1. Geology, Stratigraphic-Nomenclature-United States. I. Wright, Wilna B., joint author.

II. Title. III. Series. IV. Series: United States Geological Survey Bulletin 1422-A. QE75.B9 no. 1422-A [QE645] 557.3'08s [551.7'001'4] 76-608278

For sale by the Superintendent of Documents, U. S. Government Printing Office Washington, D. C. 20402

Stock Number 024-001-02896-4 


\section{CONTENTS}

Listing of nomenclatural changes

Restoration of the name Cove Creek Limestone for the area of the Greendale syncline in southwest Virginia, by Wallace de Witt, Jr

Abandonment of the Indian Trail Formation and distribution of certain equivalent ash-flow tuffs, eastern Nevada Test Site by G. L. Dixon, K. A. Sargent, and W. J. Carr

Correlation chart of Carboniferous rocks in Arkansas and Oklahoma, by Mackenzie Gordon, Jr

Cooper Marl in the Coastal Plain of South Carolina and Georgia, by Joseph E. Hazel

Paleobiogeography of Jurassic deposits in the conterminous United States, by Ralph W. Imlay

The Magoffin Member of the Breathitt Formation, by W. F. Outerbridge

Revision of Cretaceous nomenclature of the northern Great Plains in Montana, North Dakota, and South Dakota, by Dudley D. Rice

Age of the Mount Princeton Quartz Monzonite in central Colorado, by G. R. Scott,

R. E. Van Alstine, and W. H. Sharp

Reinstatement of the name Cape Fear Formation in North and South Carolina, by Norman F. Sohl

The Emperor Volcanic Complex of east Gogebic Range, Michigan, by Virgil A. Trent

\section{ILLUSTRATIONS}

FIGURE 1. Map showing the extent of the Mississippian rocks and the Cove Creek Limestone on the Greendale syncline

2. Map showing known distribution of the Crater Flat Tuff in the eastern part of the Nevada Test Site, Nye County, Nev

3. Map showing known distribution of the Redrock Valley Tuff in the eastern part of the Nevada Test Site, Nye County, Nev

4. Map showing known distribution of the Fraction Tuff in the eastern part of the Nevada Test Site, Nye County, Nev

5. Correlation chart of Carboniferous rocks in Arkansas and Oklahoma 



\title{
CHANGES IN STRATIGRAPHIC NOMENCLATURE BY THE U.S. GEOLOGICAL SURVEY, 1975
}

\author{
By George V. Cohee and Wilna B. Wright
}

\section{LISTING OF NOMENCLATURAL CHANGES}

In the following table, stratigraphic names adopted, revised, reinstated, or abandoned are listed alphabetically. The age of the unit, the revision, and the area involved, along with the author's name and date of publication of the report, are given. The publications in which the changes in nomenclature were made are listed in the references at the end of this publication. The capitalization of age terms in the age column follows official usage.

The following formal designations of Precambrian time are now in use by the U.S. Geological Survey:

Precambrian Z-base of Cambrian to 800 m.y.

Precambrian Y-800 m.y. to 1,600 m.y.

Precambrian X-1,600 m.y. to 2,500 m.y.

Precambrian W-older than 2,500 m.y.

For depiction on maps, only the letter designations (W, X, Y, Z) will be shown as map symbols, and lowercase letters will indicate the group or formation names as appropriate. If a unit extends across the boundary between letter-designated units, both letters, the younger first, will be used in the map symbol. When geochronologic data are not adequate for unit assignment, only the general term Precambrian and the symbol $p €$ will be used. Rock units and events within a major time unit such as $\mathrm{W}, \mathrm{X}, \mathrm{Y}$, or $\mathrm{Z}$, keyed to geochronologic data as available, will be shown on map explanations by simple sequential arrangement.

Some previously used age designations for the Precambrian are given in the table because they were used by the authors in reports submitted to the Geologic Names Committee before the new scheme was adopted. 


\begin{tabular}{lll}
\hline Name & Age & Location \\
\hline
\end{tabular}

Agua Sandstone Member Oligocene

Southern California (of Temblor Formation).

Ahloso Member (of Caney Late Mississippian (Mera- South-central Oklahoma -Shale). mecian).

Alsea Formation

Oligocene Northwestern Oregon

Andrews Schist

Cambrian(?)

North Carolina and Tennessee.

Antelope Valley Limestone Middle Ordovician or Formation.

Southern Nevada and southeastern California.

Apple Creek Formation (of Precambrian Y East-central Idaho Lemhi Group).

Arkose Ridge Formation _. Paleocene

Early and Late(?) Cretaceous.

Arroyo Penasco Formation_- Early and Late Mississip- North-central New Mexpian (Osagean, Merame- ico. cian, and Chesterian).

Aysees Member (of Ante- Middle Ordovician

Southern Nevada lope Valley Limestone).

Baird Group

Silurian to Late Devonian Northern Alaska (Gedinnian to Famennian).

Bald Eagle Formation

Late Ordovician

South-central Pennsylvania.

Barnett Hill Formation -- Middle Pennsylvanian

Southeastern Oklahoma -(Atokan).

Bassick Agglomerate Oligocene South-central Colorado _-

Bathtub Graywacke Early Cretaceous Northeastern Alaska

Battle Formation Early Pennsylvanian Northern Nevada

Becket Granite Gneiss Precambrian

Connecticut, Massachusetts, and Vermont.

Beidell Quartz Latite

Oligocene Southwestern Colorado -Belt Supergroup Precambrian Y Montana, Idaho, and Washington.

Belted Range Tuff late Miocene

Southern Nevada 
Reduced in rank to Agua Sandstone Bed and reassigned to Santos Shale Member of Temblor Formation. (Maher and others, 1975.)

Ahlosa Member (name amended to Ahloso by Elias and Branson, 1959) of Elias (1956) adopted as lowermost of three members of Caney Shale. Underlies Delaware Creek Member of Caney. (Gordon, this report, p. A54.)

Alsea Formation adopted. Conformably overlies Nestucca Formation or intervening unnamed basaltic sandstone; conformably underlies Yaquina Formation. Formerly included in upper part of Toledo Formation (now abandoned). (Snavely and others, 1975.)

Geographically extended into northwestern Georgia. (Higgins and Zietz, 1975.)

Age changed from Early and Middle Ordovician to: Middle Ordovician. (Ross and others, 1975.)

Apple Creek Phyllite of Anderson (1961) adopted as Apple Creek Formation and assigned to Lemhi Group as one of its five formations. Overlies Big Creek Formation and underlies Gunsight Formation (both new names and both assigned to Lemhi). (Rubbel, 1975.)

Age changed from Early and Late(?) Cretaceous to: Paleocene. (Beikman, 1974, 1975.)

Raised in rank to Arroyo Penasco Group and divided into (ascending): Espiritu Santo Formation and its Del Padre Sandstone Member and Terrerro Formation and its Macho, Turquillo, Manuelitas, and Cowles Members. Age changed from Late Mississippian to: Early and Late Mississippian (Osagean, Meramecian, and Chesterian). (Armstrong and Mamet, 1974.)

Age changed from Early and Middle Ordovician to: Middle Ordovician. (Ross and others, 1975.)

In its type area, western Brooks Range, age changed from Middle and Late Devonian and older(?) to: Silurian to Late Devonian (Gedinnian to Famennian); elsewhere, age changed to: Early to Late Devonian only (Siegenian? to Frasnian) and includes only Skajit Limestone. (Oliver and others, 1975.)

Bald Eagle Conglomerate of Grabau (1909) adopted as Bald Eagle Formation as used by Swartz (1948). Overlies Reedsville Shale; underlies Juniata Formation. (de Witt, 1974.)

Barnett Hill Formation of Harlton (1938) adopted. Overlies Wapanucka Limestone; correlates with Atoka Formation. (Gordon, this report, p. A54.)

Age changed from Tertiary to: Oligocene. (Scott and Taylor, 1975.)

Bathtub Graywacke adopted. Conformably overlies Kongakut Formation (new name); conformably underlies Tuktu Formation of Nanushuk Group. (Detterman and others, 1975.)

Age changed from Middle Pennsylvanian to: Early Pennsylvanian. (Erickson and Marsh, 1974.)

Becket Granite Gneiss abandoned; its rocks now included in Tyringham Gneiss (reinstated as meta-intrusive orthogneiss) and unnamed paragneiss unit. (Ratcliffe, 1974b.)

Age changed from Oligocene and older(?) to: Oligocene. (Lipman, 1975.)

In Idaho, Yellowjacket Formation and Lemhi, Hoodoo, and Swauger Quartzites removed from Belt Supergroup. Lemhi raised to group rank; name of Swauger Quartzite changed to Swauger Formation. (Rubbel, 1975.)

Tub Spring and Grouse Canyon no longer assigned to Indian Trail Formation (now abandoned) and geographically restricted to area of reassignment to Belted Range Tuff. (Dixon and others, this report, p. A49.) 


\begin{tabular}{ccc}
\hline Name & Age & Location \\
\hline Bessemer Quartzite $\ldots \ldots-\begin{array}{c}\text { Precambrian } \\
\text { Keweenawan). }\end{array}$ & $\begin{array}{c}\text { (early Northern Wisconsin and } \\
\text { northwestern Michigan. }\end{array}$
\end{tabular}

Big Creek Formation (of Precambrian Y East-central Idaho Lemhi Group).

Bigelow Brook Formation_- Ordovician(?) to Early De- Northeast-central Connecvonian(?). ticut and south-central Massachusetts.

Birdbear Member (of Jeffer- Late Devonian North Dakota, South son Formation or Dolomite).

Birdhead Sandstone Member Late Cretaceous Dakota, Montana, and Wyoming. (of Cloverly Formation).

Black Cap Limestone _..- Late Silurian or Early De- Southeastern Alaska -..vonian.

Blickensderfer Quartz Cretaceous -...-...-.-.- Northeastern Washington Monzonite.

Bloyd Formation or Shale_- Early and Middle Pennsyl- Arkansas and Oklahoma -vanian (Morrowan).

Bostwick Conglomerate Middle Pennsylvanian Member (of Lake Murray Formation) (of Dornick Hills Group).

Brallier Shale (of Sus- Late Devonian quehanna Group).

Breathitt Formation or Early and Middle Pennsyl- Kentucky, Tennessee, and Group. vanian.

South-central Oklahoma -(Atokan).

Pennsylvania, West Virginia, Virginia, and Maryland. Virginia.

Bright Angel Shale (of Middle Cambrian only in Southeastern California, Tonto Group). report area. southern Nevada and northern Arizona.

Brimfield Schist (of Putnam Ordovician(?) to Early De- Massachusetts, ConnecGroup). vonian(?). ticut, and New Hampshire.

Buck Tongue (of Mancos Late Cretaceous Colorado and Utah Shale). 
Bessemer Quartzite or Sandstone of Seaman (1944) adopted as Bessemer Quartzite. Unconformably overlies Precambrian X rocks of Marquette Range Supergroup; conformably underlies Siemens Creek Formation of Powder Mill Group (both new names). (Hubbard, 1975.)

Big Creek Formation adopted as one of five formations assigned to Lemhi Group. Overlies West Fork Formation (new name) and underlies Apple Creek Formation (both assigned to Lemhi). (Ruppel, 1975.)

Assigned to Brimfield Group (now raised in rank in northeast-central Connecticut and adjacent Massachusetts between Bonemill Brook and Eastford faults) as lowermost of three formations; underlies Hamilton Reservoir Formation (new name). Age changed from Ordovician(?) to Silurian(?) to: Ordovician(?) to Early Devonian(?). (Peper and others, 1975.)

Geographically extended into Lost River Range, east-central Idaho. (Sartenaer and Sandberg, 1974.)

Birdhead Sandstone Member of Cloverly Formation abandoned; its rocks now included in Fall River Sandstone. (Rice, this report, p. A66.)

Age changed from Middle Devonian: to Late Silurian or Early Devonian. (Oliver and others, 1975.)

Blickensderfer Quartz Monzonite adopted. Intrudes Belt Supergroup rocks (Miller, 1974a.)

Age of (1) Bloyd Formation/Shale and (2) its three upper members (Dye Shale, Kessler Limestone, and Trace Creek Shale) changed from Early Pennsylvanian (Morrowan) to: (1) Early and Middle Pennsylvanian (Morrowan) and (2) Middle Pennsylvanian (Morrowan), respectively. (Gordon, this report, p. A54.)

Bostwick Member of Tomlinson (1928) adopted as Bostwick Conglomerate Member and assigned to Lake Murray Formation of Dornick Hills Group. Overlies Otterville Limestone Member of Golf Course Formation; underlies Griffin Member of Lake Murray. (Gordon, this report, p. A54.)

In south-central Pennsylvania, name changed to Brallier Formation; name remains Brallier Shale elsewhere. (de Witt, 1974.)

In eastern Kentucky only, Magoffin Beds of Morse (1931) adopted and redefined as Magoffin Member and assigned to Breathitt Formation. (Outerbridge, this report, p. A64.)

Geographically extended into south-central Utah subsurface. (Peterson and Barnum, 1973a, b.)

Raised to group rank in northeast-central Connecticut and adjacent Massachusetts between Bonemill Brook and Eastford faults. Divided into (ascending): Bigelow Brook Formation, Hamilton Reservoir Formation (new name), and Mount Pisgah Formation (new name). Age changed from Middle(?) Ordovician or older to: Ordovician(?) to Early Devonian(?). Former rank, group affiliation, and age remain unchanged in other areas. (Peper and others, 1975.)

Loyd Sandstone Member of Mancos Shale reduced in rank to Loyd Sandstone Bed of Buck Tongue of Mancos Shale in area of this report, northwestern Colorado. Farther east of Colorado where Buck Tongue has merged with main body of Mancos, Loyd remains member of Mancos. (Hail, 1974.)

Cambria Felsite of Ernst and Hall (1974) adopted. Unconformably overlies Franciscan rocks; unconformably underlies Lospe Formation. (Hall, 1974.) 


\begin{tabular}{lll}
\hline Name & Age & Location \\
\hline
\end{tabular}

Caney Shale

Late Mississippian (Mera- Oklahoma and Arkansas.mecian and Chesterian).

Cape Fear Formation

Late Cretaceous

Southeastern North Carolina.

Carey Dolomite

Early and Middle Devonian Central Idaho

(Emsian and Eifelian).

Castine Volcanics Late Silurian and Early Maine

Devonian.

Catskill Formation (of Sus- Late Devonian and Early Eastern Pennsylvania quehanna Group).

Mississippian.

Cedar Butte Basalt

Pleistocene

Southeastern Idaho

Cedar Cove Formation

Middle and Late Devonian Southeastern Alaska

Central Plateau Member (of Pleistocene

Wyoming

Plateau Rhyolite).

Chainman Shale or Forma- Early and Late Mississip- Nevada, California, and tion.

pian.

Utah.

Chalk Mountain Rhyolite Oligocene

Central Colorado

Charles Formation (of Late Mississippian

Subsurface in central and Madison Group).

eastern Montana and western parts of the Dakotas.

Chatanikz Ash Bed (of Pleistocene (Wisconsinan)_- East-central Alaska Goldstream Formation).

Chena Alluvium

Pleistocene and Holocene East-central Alaska (Illinoian? to Holocene).

Chickasaw Creek Shale or Late Mississippian (Ches- Eastern Oklahoma and Chickasaw Creek Mem- terian). western Arkansas. ber (of Stanley Group or of Stanley Shale).

Chino Valley Formation -- Cambrian(?)

Northwestern Arizona

Claiborne Group middle Eocene

Alabama, Louisiana, Texas, Georgia, Mississippi, Arkansas, Kentucky, and Tennessee.

Cloverly Formation

Early Cretaceous Wyoming, Montana, Colorado, and Utah. 
In northern Arbuckle Mountains of south-central Oklahoma, divided into (ascending): Ahloso (Meramecian), Delaware Creek (Chesterian, and Sand Branch (Chesterian) Members. In southern Arbuckle Mountains of south-central Oklahoma, assigned to Springer Group with its Delaware Creek Member only. Overlies Sycamore Limestone; underlies Goddard Shale of Springer Group. (Gordon, this report, p. A54.)

Reinstated in North Carolina and geographically extended into eastern South Carolina. Its rocks formerly assigned to Tuscaloosa Formation (now no longer used in North and South Carolina-a geographic restriction). Overlies Piedmont complex; underlies Black Creek Formation in coastal areas and Middendorf Formation in updip areas. Age is Late Cretaceous (pre-late Austinian). (Sohl, this report, p. A68.)

Carey Dolomite adopted. Overlies Milligen(?) Formation (lower contact covered); underlies Jefferson Formation. (Skipp and Sandberg, 1975.)

Age changed from Early Devonian to: Late Silurian and Early Devonian. (Stewart and Wones, 1974.)

In eastern Pennsylvania, Duncannon Member of Dyson (1967) adopted as member of Catskill. Overlies Clarks Ferry Member; underlies Spechty Kopf Member. (Wood, 1974.)

Assigned to Snake River Group in southeastern Idaho only. (Crosthwaite, 1974.)

Age changed from Middle and Late(?) Devonian to: Middle and Late Devonian. (Loney and others, 1975.)

Stratigraphically extended to include unnamed tuffs of Cold Mountain Creek and Bluff Point (formerly included in Shoshone Lake Tuff Member of Plateau, now abandoned). (Christiansen and Blank, 1974a; Christiansen, 1974, 1975.)

Age changed from Late Mississippian to: Early and Late Mississippian. (Smith and Ketner, 1975.)

Age changed from Eocene to: Oligocene. (Tweto, 1974.)

Geographically and stratigraphically restricted to subsurface Williston basin of central and eastern Montana and western parts of the Dakotas; the name was formerly extended to surface rocks in part of central and western Montana and included beds considered to be part of underlying Mission Canyon Limestone. (Sando and Dutro, 1974.)

Chatanika Ash Bed adopted as bed within Goldstream Formation (newly named). (Péwé, 1975a.)

Chena Alluvium adopted. Unconformably overlies bedrock or intervening Cripple Gravel or Tanana Formation (both newly named). (Péwé, 1975a.)

Chickasaw Creek Shale of Harlton (1938) adopted as Chickasaw Creek Shale of Stanley Group in eastern Oklahoma and as Chickasaw Creek Member or its equivalent of Stanley Shale in western Arkansas. Overlies Moyers Formation or Member; underlies Wildhorse Mountain Formation or Jackfork Sandstone. (Gordon, this report, p. A54.) Chino Valley Formation adopted. Conformably overlies Tapeats Sandstone or Bright Angel Shale; conformably underlies Martin Formation. (Hereford, 1975.)

In western Tennessee only, reduced in rank to Claiborne Formation; usage remains unchanged elsewhere. (Parks and Russell, 1975.)

In south-central Montana only, Cloverly Formation and its Birdhead Sandstone Member abandoned; their rocks now included in Kootenai Formation and overlying Fall River Sandstone. Cloverly usage elsewhere remains unchanged. (Rice, this report, p. A66.) 


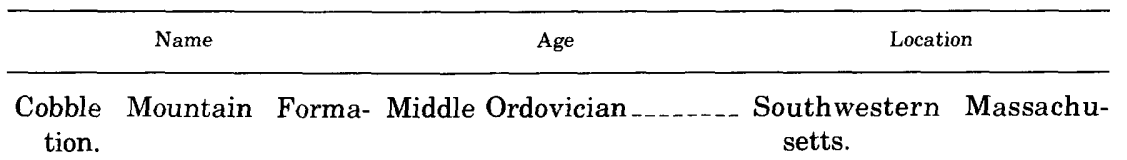

Colville Group Late Cretaceous Northern Alaska

Conejos Formation Oligocene (31.1-34.7 m.y.)__ Southwestern Colorado and northwestern New Mexico.

Coon Creek Tongue (of Rip- Late Cretaceous

Tennessee, Mississippi, ley Formation). Kentucky(?), and Illinois(?).

Cooper Marl late Eocene, Oligocene, and Coastal Plain of South early Miocene(?) Carolina and Georgia.

Copper Basin Formation -- Early and Late Mississip- South-central Idaho pian.

Copps Formation Precambrian X

Northwestern Wisconsin and northwestern Michigan.

Corset Spring Shale Late Cambrian Western Utah and eastern Nevada.

Cortlandt Complex Late Ordovician and Early New York Silurian.

Cosumnes Formation Late Jurassic or older Central California

Cottonwood Wash Tuff Oligocene Southwestern Utah Member (of Needles Range Formation).

Coughs Creek Tongue (of Eocene Southwestern Colorado _Green River Formation).

Covada Group

Pennsylvanian(?) north-central Washington.

Cove Creek Limestone Late Mississippian (Ches- Southwestern Virginia terian).

Cowles Member (of Terrerro Late Mississippian (Ches- North-central New MexFormation) (of Arroyo terian). ico.

Penasco Group).

Crater Flat Tuff

Miocene

Southern Nevada

Cripple Gravel late Pliocene and (or) early East-central Alaska Pleistocene. 
Revision and reference

Cobble Mountain Formation adopted. Overlies Moretown Formation; underlies Goshen or Russell Mountain Formation; in large part, is facies equivalent of Hawley Formation. Divided into (ascending): unnamed thin-bedded and thick-bedded members. (Hatch and Stanley, 1973.)

Geographically extended into northeastern Alaska, replacing upper part of Ignek Formation (now abandoned) with its lowermost Seabee Formation. (Detterman and others, 1975.)

Age changed from Oligocene and older(?) to: Oligocene (31.1-34.7 m.y.). (Lipman, 1975.)

In western Tennessee, raised in rank to Coon Creek Formation; Ripley Formation geographically restricted from usage in Tennessee. Coon Creek usage remains unchanged elsewhere. (Parks and Russell, 1975.)

Age changed from early to late Oligocene to: late Eocene, Oligocene, and early Miocene(?). (Hazel, this report, p. A54.)

Age changed from Late Pennsylvanian to Early Permian to: Early and Late Mississippian. (Skipp and Hall, 1975.)

Copps Formation of Allen and Barrett (1915) adopted. Overlies Emperor Volcanic Complex (new name) and Ironwood Iron-formation; underlies lower Keweenawan rocks. (Trent, this report, p. A69.)

In Confusion and adjacent House Ranges of western Utah, reduced in rank to Corset Spring Shale Member and assigned to Orr Formation. Overlies Johns Wash Limestone Member (also reduced in rank in these areas only). Former usage remains unchanged elsewhere. (Hintze, 1974b.)

Age changed from undetermined to: Late Ordovician and Early Silurian. (Ratcliffe and Harwood, 1975.)

Cosumnes Formation abandoned; its rocks form scattered fault-bounded blocks in a melange and are no longer considered a demonstrable rock-stratigraphic unit. (Duffield and Sharp, 1975.)

Cottonwood Wash Tuff Member of Best and others (1973) adopted as lower member of Needles Range Formation. Conformably underlies Wah Wah Springs Tuff Member of Needles Range. (Hintze, 1974a.)

Coughs Creek Tongue adopted and assigned to upper part of Green River Formation, intertonguing with lower part of overlying Uinta Formation. (O'Sullivan, 1975.)

Age changed from probably Devonian, Carboniferous, and Mesozoic to: Pennsylvanian(?). (Fox and Rinehart, 1974.)

Cove Creek Limestone reinstated. Overlies Fido Sandstone; underlies Pennington Shale. Age changed from Mississippian to: Late Mississippian (Chesterian). (de Witt, this report, p. A46.)

Age changed from Early Mississippian to: Late Mississippian (Chesterian). (Armstrong and Mamet, 1974.)

Indian Trail Formation abandoned. Its rocks now included in (ascending): Fraction Tuff, Redrock Valley Tuff, and Crater Flat Tuff (all three now geographically extended). Indian Trails two members (ascending)-_Tub Spring and Grouse Canyon-now geographically restricted to area of assignment to Belted Range Tuff. (Dixon and others, this report, p. A49.)

Cripple Gravel adopted. Overlies bedrock or auriferous clay layer; underlies mainly Fox Gravel and Tanana Formation and locally Dawson Cut Formation, Fairbanks Loess, Gold Hill Loess, or Goldstream Formation (all except Fairbanks newly named). (Péwé, 1975a.) 


\begin{tabular}{lll}
\hline Name & Age & Location \\
\hline
\end{tabular}

Crystal Peak Dolomite _.-.- Ordovician

Western Utah

Cut Bank Sandstone Early Cretaceous

Northwestern Montana Member (of Kootenai

Formation).

Dalton Formation late Precambrian(?) and Massachusetts and New Early Cambrian.

Darrough Felsite middle Tertiary York.

Dawson Cut Formation Pleistocene (Yarmouth- East-central Alaska ian).

Dedham Granodiorite .... Precambrian Z Massachusetts and Rhode Island.

Deer Peak Volcanics

Oligocene South-central Colorado _--

Delaware Creek Member (of Late Mississippian (Ches- South-central Oklahoma -Caney Shale). terian).

Del Padre Sandstone Early and Late Mississip- North-central New MexMember (of Espiritu pian. ico.

Santo Formation) (of Arroyo Penasco Group).

Devils Hole Formation _._- early Oligocene early Oligocene .......... South-central Colorado _.

Dome Ash Bed (of Gold Hill Pleistocene (late Illinoian)_- East-central Alaska Loess).

Dornick Hills Formation _- Early and Middle Pennsyl- South-central Oklahoma -vanian.

Duncannon Member (of Early Devonian Eastern Pennsylvania Catskill Formation).

Duzel Formation Late Ordovician(?) Northwestern California --

Dye Shale Member (of Middle Pennsylvanian Arkansas Bloyd Formation or (Morrowan). Shale).

Eagle Creek Formation (of Early and Late Permian .. Southern Alaska Mankomen Group).

Eagle River Porphyry _.-- Early Permian Central Colorado

Echooka Member (of Sad- Paleocene(?) Northern Alaska lerochit Formation).

Elbert Formation Late Devonian Colorado and New Mexico.

Eli Formation (of Baird Middle and Late Devonian Northwestern Alaska -..-Group).

(Givetian to Famennian). 
Crystal Peak Dolomite of Webb (1956) adopted. Overlies Watson Ranch Quartzite; underlies Eureka Quartzite. (Hintze, 1974c.)

Cut Bank sand (economic term) adopted as Cut Bank Sandstone Member of Kootenai Formation as defined by Oakes (1966). Basal member of Kootenai; underlies Sunburst Sandstone Member of Kootenai (Oakes's Lander member). (Rice, this report, p. A66.)

Age changed from Early Cambrian(?) to: late Precambrian and Early Cambrian. (Ratcliffe, 1974a.)

Age changed from Permian(?) to: middle Tertiary. (Speed and McKee, 1974.)

Dawson Cut Formation adopted. Overlies Cripple or Fox Gravel and unconformably underlies Gold Hill Loess or Goldstream Formation (all four newly named). (Péwé, 1975a.)

Age changed from Precambrian(?) to: Precambrian Z. (Nelson, 1975.)

Deer Peak Volcanics adopted. Overlies unnamed Precambrian rocks; underlies Santa Fe(?) Formation; interfingers with Devils Hole Formation. (Scott and Taylor, 1975.)

Delaware Creek Member of Elias (1956) adopted as middle of three members of Caney Shale. Overlies Ahloso Member of Caney; underlies Sand Branch Member of Caney. (Gordon, this report, p. A54.)

Del Padre Sandstone of Sutherland (1963a) adopted as basal member of Espiritu Santo Formation. (Armstrong and Mamet, 1974.)

Age changed from late Eocene to: early Oligocene. (Scott and Taylor, 1975.)

Dome Ash Bed adopted as bed within top part of Gold Hill Loess (newly named). (Péwé, 1975a.)

Raised in rank to Dornick Hills Group. Divided into (ascending): Golf Course Formation and its Primrose Sandstone (lower and upper parts), Gene Autry, Jolliff, and Otterville Limestone Members (now reduced from formation rank); and Lake Murray Formation and its Bostwick Conglomerate and Griffin Members. Overlies rocks of Springer Group (now raised from formation rank). (Gordon, this report, p. A54.)

Duncannon Member of Dyson (1967) adopted. Overlies Clarks Ferry Member; underlies Spechty Kopf Member. (Wood, 1974.)

Duzel Formation abandoned as no longer considered valid formational unit; its rocks will be included in six lithologic units to be established. (Hotz, 1974.)

Age changed from Early Pennsylvanian (Morrowan) to: Middle Pennsylvanian (Morrowan). (Gordon, this report, p. A54.)

Eagle Creek Formation adopted as upper of two formations in Mankomen Group (newly raised in rank). Conformably overlies Slana Spur Formation (new name) of Mankomen; conformably underlies unnamed chert and limestone or unconformably underlies Nikolai Greenstone. (Richter and Dutro, 1975.)

Age changed from early Tertiary to: Paleocene(?). (Tweto, 1974.)

Raised in rank to Echooka Formation, lower of two formations of Sadlerochit Group (now also raised in rank). Divided into two newly named members (ascending): Joe Creek and Ikiakpaurak Members. Age changed from Late Permian to: Early and Late Permian. (Detterman and others, 1975.)

Geographically extended into south-central Utah subsurface. (Peterson and Barnum, 1973a, b.)

Age changed from Late Devonian to: Middle and Late Devonian (Givetian to Famennian). (Oliver and others, 1975.) 


\begin{tabular}{|c|c|c|}
\hline Name & Age & Location \\
\hline Elk Mountain Porphyry -- & $\begin{array}{l}\text { Late Cretaceous or Paleo- } \\
\text { cene. }\end{array}$ & Central Colorado \\
\hline Ellsworth Schist__._. & $\begin{array}{l}\text { Cambrian(?) and Ordovi- } \\
\text { cian(?). }\end{array}$ & Maine .... \\
\hline Ellsworth Shale & $\begin{array}{l}\text { Late Devonian and Early } \\
\text { Mississippian. }\end{array}$ & Michigan _...- \\
\hline $\begin{array}{l}\text { El Paso Limestone or Dolo- } \\
\text { mite or Formation. }\end{array}$ & $\begin{array}{l}\text { Late Cambrian (locally } \\
\text { only) and Early Ordovi- } \\
\text { cian. }\end{array}$ & $\begin{array}{l}\text { Texas, New Mexico, and } \\
\text { Arizona. }\end{array}$ \\
\hline
\end{tabular}

Ely Springs Dolomite -.-- Middle and Late Ordovi- South and southeastern cian. Nevada and southeastern California.

Emperor Volcanic Com- Precambrian X plex.

Northern peninsula, Michigan.

Engineer Loess

Holocene

East-central Alaska

Espiritu Santo Formation_. Early and Late Mississip- North-central New Mexpian (Osagean and ico.

Meramecian).

Esplanade Sandstone Early Permian (Wolfcamp- Northwestern Arizona -...Member (of Supai Forma- ian).

tion).

Ester Ash Bed (in the up- Pleistocene (early Illino- Alaska (east of Fairland silt).

ian). banks).

Ester Ash Bed (of Fairbanks Pleistocene (Illinoian) East-central Alaska Loess).

Eva Formation

Pleistocene (Sangamon- East-central Alaska ian).

Everett Formation

Early Cambrian(?) and (or) late Precambrian(?).

Fairbanks Loess Pleistocene (Illinoian and Alaska Wisconsin) and Holocene.

Fan Lake Granodiorite _- Cretaceous Northeastern Washington.

Fillmore Formation (of Early Ordovician Southwestern Utah Pogonip Group).

Fire Creek Siltstone Early Triassic Northeastern Alaska Member (of Ivishak Formation) (of Sadlerochit Group). 
Revision and reference

Age changed from early Tertiary to: Late Cretaceous or Paleocene. (Tweto, 1974.)

Age changed from Precambrian or Cambrian to: Cambrian(?) and Ordovician(?). (Stewart and Wones, 1974.)

Geographically extended in the subsurface into north-central Indiana. (Marie, 1975.)

In western Texas (type locality) and southern New Mexico, El Paso raised to group rank and divided into (ascending): Hitt Canyon Formation (new name), McKelligon Limestone, and Padre Formation (new name), all of Early Ordovician age. El Paso Limestone/Dolomite/Formation remains good usage elsewhere. (Hayes, 1975.)

Geographically extended into Wah Wah Mountains and Confusion and Howe Ranges, western Utah, replacing Fish Haven Dolomite (now geographically restricted from usage in these areas). Age is Late Ordovician only, but remains unchanged elsewhere. (Hintze, 1974a.)

Emperor Volcanic Complex adopted; divided into Wolf Mountain Creek Formation (new name) in its upper part and Brotherton sill as its feeder. Intertongues with Ironwood Iron-formation; overlies Palms Formation and underlies Copps Formation. (Trent, this report, p. A69.)

Engineer Loess adopted; locally includes Wilber (newly named), Jarvis, and White River Ash Beds. Disconformably overlies Goldstream Formation (newly named); downslope, grades into Ready Bullion Formation (newly named), and upslope, grades into and is equivalent of upper part of Fairbanks Loess. (Péwé, 1975a.)

Assigned to Arroyo Penasco Group (newly raised in rank) as lower of two formations. Unconformably overlies Precambrian igneous and metamorphic rocks; unconformably underlies Tererro Formation of Arroyo Penasco. Includes Del Padre Sandstone Member. Age changed from Devonian(?) to: Early and Late Mississippian (Osagean and Meramecian). (Armstrong and Mamet, 1974).

Esplanade Sandstone Member raised in rank to Esplanade Sandstone and assigned to Supai Group (now raised from formation rank) as uppermost of four formations. Unconformably overlies Wescogame Formation (new name) of Supai Group; unconformably underlies Hermit Shale. Age changed from Permian to Early Permian (Wolfcampian). (McKee, 1975.)

Ester Ash Bed now included in Fairbanks Loess. (Péwé, 1975b.)

Geographically extended and reassigned to Gold Hill Loess; continues to occur within Fairbanks Loess elsewhere. (Péwé, 1975a.)

Eva Formation adopted. Unconformably overlies Gold Hill Loess and conformably underlies and grades into Goldstream Formation (both newly named). (Péwé, 1975a.)

Age changed from Cambrian(?) and Cambrian to: (Early Cambrian(?) and (or) late Precambrian(?). (Ratcliffe, 1974a.)

Includes Ester Ash Bed of Illinoian age east of Fairbanks. Age changed from Pleistocene to: Pleistocene (Illinoian and Wisconsin) and Holocene. (Péwé. 1975b.)

Fan Lake Granodiorite adopted. Intrudes Precambrian rocks; intruded by Cretaceous or Tertiary granodiorite dikes. (Miller, 1974b.)

Fillmore Limestone of Hintze (1951) adopted as Fillmore Formation and assigned to Pogonip Group. Conformably overlies House Limestone and conformably underlies Wah Wah Limestone, both of Pogonip Group. (Hintze, 1974a.)

Fire Creek Siltstone Member adopted and assigned, as uppermost of three newly named members, to Ivishak Formation of Sadlerochit Group (both now raised in rank). Conformably overlies Ledge Sandstone Member (new name) of Ivishak; conformably(?) and disconformably(?) underlies Shublik Formation. (Detterman and others, 1975.) 


\begin{tabular}{|c|c|c|}
\hline Name & Age & Location \\
\hline Fish Haven Dolomite & Late Ordovician -- & $\begin{array}{l}\text { Utah, southeastern Idaho, } \\
\text { and eastern Nevada. }\end{array}$ \\
\hline Flechado Formation & $\begin{array}{l}\text { Early and Middle Pennsyl- } \\
\text { vanian (Morrowan to Des } \\
\text { Moinesian). }\end{array}$ & $\begin{array}{l}\text { North-central New Mex- } \\
\text { ico. }\end{array}$ \\
\hline $\begin{array}{l}\text { Flowery Trail Granodio- } \\
\text { rite. }\end{array}$ & $\begin{array}{l}\text { Late Triassic or Early } \\
\text { Jurassic. }\end{array}$ & Northeastern Washington.- \\
\hline Foreknobs Formation & Late Devonian & $\begin{array}{l}\text { Southwestern Pennsylva- } \\
\text { nia and northern West } \\
\text { Virginia. }\end{array}$ \\
\hline Fox Gravel & $\begin{array}{l}\text { early or middle Pleisto- } \\
\text { cene. }\end{array}$ & East-central Alaska ...... \\
\hline
\end{tabular}

Fraction Tuff or Breccia _- Miocene

Southern and southwestern Nevada.

Franconia Sandstone _..-- Late Cambrian Minnesota

Franklin Bluffs Member (of Oligocene(?) and Mio- Northeastern Alaska Sagavanirktok Forma- cene(?). tion).

Furnace Limestone _...-.- Early Cambrian to Per- Southern California $\operatorname{mian}(?)$.

Gakona Formation _...-. Oligocene _............. Alaska

Galena Point Granodio- Cretaceous (98.3 \pm 3.2 Northeastern Washington rite. m.y.). and northwestern Idaho.

Game Refuge Sandstone -- Early Pennsylvanian (early Southeastern Oklahoma -Morrowan).

Garda Stade

Holocene

Washington

Gene Autry Member (of Early and Middle Pennsyl- South-central Oklahoma -Golf Course Formation) vanian (Morrowan). (of Dornick Hills Group).

Glory Hole Volcanics Late Cretaceous South-central Arizona

Goat Hill Member (of Log- Late Jurassic Central California town Ridge Formation).

Goddard Shale Member (of Late Mississippian (Ches- South-central Oklahoma -. Springer Formation). terian). 
Geographically restricted from Wah Wah Mountains and Confusion and Howe Ranges, western Utah; replaced by Ely Springs Dolomite (now geographically extended into these areas). (Hintze, 1974a.)

Flechado Formation of Sutherland (1963a, b) and Sutherland and Harlow (1973) adopted. Unconformably overlies Arroyo Penasco Group (Tererro Formation); conformably underlies Alamitos Formation of Sutherland (1963b). (Armstrong and Mamet, 1974.)

Age changed from Mesozoic(?) to Late Triassic or Early Jurassic. (Engels, 1975.)

Foreknobs Formation of Dennison (1970) adopted. Overlies Scherr Formation (not new); underlies Hampshire Formation. (de Witt, 1974.)

Fox Gravel, a valley-bottom accumulation of solifluction material, adopted. Unconformably overlies Precambrian bedrock; conformably underlies Dawson Cut Formation, Fairbanks Loess, Gold Hill Loess, or Goldstream Formation; grades laterally into Tanana Formation in valley bottoms (all except Fairbanks new names). (Péwé, 1975a.)

Indian Trail Formation abandoned. Its rocks now included in (ascending): Fraction Tuff, Redrock Valley Tuff, and Crater Flat Tuff (all three now geographically extended). Indian Trail's two members (ascending-Tub Spring and Grouse Canyon- now geographically restricted to area of reassignment to Belted Range Tuff. (Dixon and others, this report, p. A49.)

In Minnesota only, Franconia redefined by Austin (1969); overlies Ironton Sandstone (newly raised to formation rank in Minnesota). (Lindholm and others, 1974.)

Franklin Bluffs Member adopted as middle of three members of Sagavanirktok Formation. Conformably(?) overlies Sagwon Member (new name) of Sagavanirktok; conformably underlies Nuwok Member of Sagavanirktok or unconformably underlies Quaternary gravel. (Detterman and others, 1975.)

Age changed from Paleozoic to: Early Cambrian to Permian(?). (Stewart and Poole, 1975.)

Age changed from late Eocene to: Oligocene. (Beikman, 1974.)

Galena Point Granodiorite adopted. Intrudes Belt Supergroup rocks. (Miller, 1974a.)

Game Refuge Formation of Harlton (1959) adopted as Game Refuge Sandstone, uppermost of five named formations of Jackfork Group. Overlies Wesley Shale of Jackfork; underlies Johns Valley Shale. (Gordon, this report, p. A54.)

Garda Drift assigned to Garda Stade in Winthrop Creek Glaciation. (Crandell and Miller, 1974.)

Gene Autry Shale of Elias (1956) adopted as Gene Autry Member (reduced in rank) and assigned to Golf Course Formation of Dornick Hills Group. Overlies Primrose Sandstone Member of Golf Course; underlies Jolliff Member of Golf Course. (Gordon, this report, p. A54.)

Age changed from Late Cretaceous and (or) early Tertiary to: Late Cretaceous. (Krieger, 1974.)

Goat Hill Member adopted as one of four new members of Logtown Ridge Formation. Conformably overlies Rabbit Hill Member; conformably underlies Pokerville Member southward to Jackass Gulch area, beyond which it becomes uppermost member. (Duffield and Sharp, 1975.)

Raised in rank to Goddard Shale and assigned to Springer Group as one of five named formations. Divided into (ascending): unnamed lower shale member, Redoak Hollow Member, and unnamed upper shale member. Overlies Caney Shale and its Delaware Creek Member; underlies Overbrook Sandstone. (Gordon, this report, p. A54.) 


\begin{tabular}{lll}
\hline Name & Age & Location \\
\hline
\end{tabular}

Gold Hill Loess Pleistocene (Illinoian)

East-central Alaska

Goldstream Formation Pleistocene (Wisconsinan)__ East-central Alaska

Golf Course Formation (of

Dornick Hills Group).

Early and Middle Pennsyl- South-central Oklahoma -vanian (Morrowan).

Goon Dip Greenstone Triassic(?) Southeastern Alaska

Goose Lake Member (of Precambrian Y(?) Northwestern Michigan -Siamo Slate) (of Menominee Group) (of Marquette Range Supergroup).

Great Smoky Group (of Precambrian Ocoee Series).

Georgia, Tennessee, and North Carolina.

Greenhorn Limestone or Late Cretaceous Colorado, Kansas, MonFormation or Shale, etc. (of Colorado Group). tana, Nebraska, New Mexico, North Dakota, South Dakota, and Wyoming.

Green River Formation __- early and middle Eocene _. Wyoming, Colorado, and Utah.

Griffin Member (of Lake Middle Pennsylvanian South-central Oklahoma -Murray Formation) (of (Atokan).

Dornick Hills Group).

Grouse Canyon Member (of late Miocene Southern Nevada Indian Trail Formation or of Belted Range Tuff).

Gunsight Formation (of Precambrian Y Lemhi Group). East-central Idaho

Hales Limestone Late Cambrian and Early South-central Nevada Ordovician.

Hamilton Reservoir Forma- Orodvician(?) to Early De- Northeast-central Connection (of Brimfield Group). v vonian(?). ticut and adjacent Massachusetts.

Hampshire Formation Late Devonian West Virginia and Virginia. 
Gold Hill Loess adopted; locally includes Ester and Dome (newly named) Ash Beds. Unconformably overlies pre-Quaternary bedrock, Cripple Gravel, Fox Gravel, Tanana Formation, and Dawson Cut Formation and unconformably underlies Eva and Goldstream Formations (all six newly named). Lateral equivalent of lower part of Fairbanks Loess. (Péwé, 1975a.)

Goldstream Formation adopted; locally includes Chatanika Ash Bed (new name). Unconformably overlies Fox Gravel or intervening Tanana Formation or Gold Hill Loess and conformably overlies Eva Formation; unconformably underlies Engineer Loess or Ready Bullion Formation (all six newly named). (Péwé, 1975a.)

Golf Course Formation of Harlton (1956) adopted and assigned to Dornick Hills Group (now raised in rank). Divided into (ascending): Primrose Sandstone Member (lower and upper parts), Gene Autry Member, Jolliff Member, and Otterville Limestone Member (now reduced from formation rank). Overlies rocks of Springer Group (now raised from formation rank); underlies Lake Murray Formation of Dornick Hills Group. (Gordon, this report, p. A54.)

Assigned to Kelp Bay Group as basal formation; underlies Whitestripe Marble. Age changed from Permian(?) and Triassic(?) to: Triassic(?). (Loney and others, 1975.)

Goose Lake Member of Tyler and Twenhofel (1952) adopted as member of Siamo Slate. Overlies unnamed lower slate unit of Siamo; underlies unnamed middle slate unit of Siamo. (Gair, 1975.)

Changed from subdivision of Ocoee Series to subdivision of Ocoee Supergroup. (Higgins and Zietz, 1975.)

Geographically extended into north-central and central Montana, and in those areas only Mosby Sandstone Member of Warm Creek Shale (now abandoned) reassigned to Greenhorn Formation. Greenhorn usage elsewhere remains unchanged. (Rice, this report, p. A66.)

In northwestern Colorado, Coughs Creek Tongue adopted and assigned to upper part of Green River Formation, intertonguing with lower part of overlying Uinta Formation. (O’Sullivan, 1975.)

Griffin Sandstone Member of Harlton (1956) adopted as Griffin Member and assigned to Lake Murray Formation of Dornick Hills Group. Overlies Bostwick Conglomerate Member of Lake Murray. (Gordon, this report, p. A54.)

Indian Trail Formation abandoned. Its rocks now included in (ascending): Fraction Tuff, Redrock Valley Tuff, and Crater Flat Tuff (all three now geographically extended). Indian Trail's two members (ascending)_-Tub Spring and Grouse Canyon-now geographically restricted to area of reassignment to Belted Range Tuff. (Dixon and others, this report, p. A49.)

Gunsight Formation adopted as uppermost of five formations assigned to Lemhi Group. Overlies Apple Creek Formation of Lemhi; underlies Swauger Formation or Kinnikinic Quartzite. (Ruppel, 1975.)

Age changed from Late Cambrian to: Late Cambrian and Early Ordovician. (Quinlivan and Rogers, 1974.)

Hamilton Reservoir Formation adopted and assigned to Brimfield Group (now raised in rank in northeast-central Connecticut and adjacent Massachusetts between Bonemill Brook and Eastford faults). Overlies Bigelow Brook Formation and underlies Mount Pisgah Formation (new name), both assigned to Brimfield Group. (Peper and others, 1975.)

Geographically extended into south-central Pennsylvania. (de Witt, 1974.) 


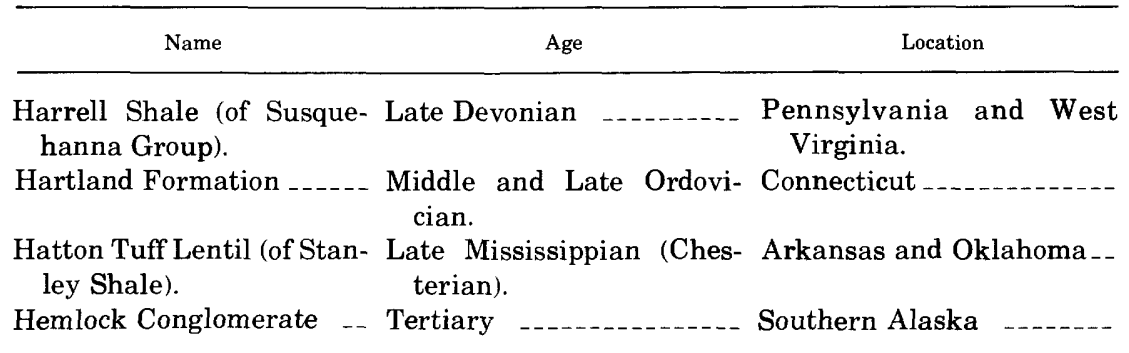

Highway Limestone

Middle and Early Pennsyl- Northern Nevada vanian.

Hitt Canyon Formation (of Early Ordovician Westernmost Texas and El Paso Group). southern New Mexico.

Hoodoo Quartzite Precambrian Y East-central Idaho

Horseshoe Mesa Member (of Late Mississippian Arizona Redwall Limestone). Howell Formation Middle Cambrian Western Utah

Ignek Formation Early and Late Cretaceous. Northern Alaska

Ikiakpaurak Member (of Late Permian Northeastern Alaska Echooka Formation) (of Sadlerochit Group).

Indian Trail Formation _. Miocene Southern Nevada

Inyo Creek Formation (of Precambrian Y Lemhi Group).

Ironton Sandstone Member Late Cambrian East-central Idaho (of Franconia Sandstone).

Islesboro Formation Cambrian(?) and Ordovi- Maine cian(?).

Ivishak Member (of Sad- Early Triassic lerochit Formation).

Jackfork Sandstone Late Mississippian and Oklahoma and Arkansas_Early Pennsylvanian (latest Chesterian and Morrowan).

Jarvis Ash Bed (of Engi- Holocene East-central Alaska neering Loess). 
In south-central Pennsylvania, name changed to Harrell Formation; name remains Harrell Shale elsewhere. (de Witt, 1974.)

Age changed from Paleozoic to: Middle and Late Ordovician. (Schnabel, 1974.)

Age changed from Mississippian to: Late Mississippian (Chesterian). (Gordon, this report, p. A54.)

Hemlock Conglomerate of Laughbaum (Alaska Geol. Soc., 1970) and Calderwood and Fackler (1972) adopted. Overlies West Foreland Formation; underlies Tyonek Formation. (Adkison, 1975.)

Age changed from Middle Pennsylvanian to: Middle and Early Pennsylvanian. (Erickson and Marsh, 1974.)

Hitt Canyon Formation adopted as lowermost of three formations assigned to El Paso Group (raised to group rank in westernmost Texas and southern New Mexico); underlies McKelligon Limestone (newly adopted, of Flower, 1964). (Hayes, 1975.)

Hoodoo Quartzite no longer assigned to Belt Supergroup. Age changed from Precambrian to: Precambrian Y. (Ruppel, 1975.)

Geographically extended into south-central Utah subsurface. (Peterson and Barnum, $1973 a$, b.)

Name changed from Howell Formation to Howell Limestone everywhere. Includes Millard Member at base in Wah Wah Mountains and House Range. (Hintze, 1974d.)

Ignek Formation abandoned; its rocks now reassigned to upper part of Kongakut Formation (new name) and overlying Seabee Formation of Colville Group. (Detterman and others, 1975.)

Ikiakpaurak adopted and assigned, as upper of two members, to Echooka Formation of Sadlerochit Group (both now raised in rank). Conformably overlies Joe Creek Member (new name) of Echooka; conformably to disconformably underlies Kavik Member (new name) of Ivishak Formation. (Detterman and others, 1975.)

Indian Trail Formation abandoned. Its rocks now included in (ascending): Fraction Tuff, Redrock Valley Tuff, and Crater Flat Tuff (all three now geographically extended). Its two members (ascending)-Tub Spring and Grouse Canyon-now geographically restricted to area of assignment to Belted Range Tuff. (Dixon and others, this report, p. A49.)

Inyo Creek Formation adopted as lowermost of five formations assigned to Lemhi Group. Faulted at base; underlies West Fork Formation (new name) of Lemhi. (Ruppel, 1975.)

In Minnesota only, Ironton Sandstone Member of Franconia removed from Franconia and raised to formation rank as redefined by Austin (1969); elsewhere, Ironton remains in good usage as member of Franconia. (Lindholm and others, 1974.)

Age changed from Cambrian(?) to: Cambrian(?) and Ordovician(?). (Stewart and Wones, 1974.)

Raised in rank to Ivishak Formation, upper of two formations of Sadlerochit Group (now also raised in rank). Divided into three newly named members (ascending): Kavik, Ledge Sandstone, and Fire Creek Siltstone Members. (Detterman, and others, 1975.)

In southeastern Oklahoma, Jackfork Sandstone raised in rank to Jackfork Group and divided into (ascending): Wildhorse Mountain Formation, Prairie Mountain Formation, Markham Mill Formation, Wesley Shale, Game Refuge Sandstone (all newly adopted of Harlton, 1938, 1959). In southwestern Arkansas, Jackfork Sandstone remains in good usage. (Gordon, this report, p. A54.)

Jarvis Ash Bed of Reger, and others (1964) adopted as bed within Engineer Loess (newly named) near junction of Delta and Tanana Rivers. (Péwé, 1975a.) 


\begin{tabular}{lll}
\hline Name & Age & Location \\
\hline
\end{tabular}

Joe Creek Member (of Early and Late Permian_- Northeastern Alaska Echooka Formation) (of

Sadlerochit Group).

Johnson Gulch Porphyry -- Late Cretaceous or Paleo- Central Colorado cene.

Johns Valley Shale

Early and Middle Pennsyl- Oklahoma and Arkansas_vanian (Morrowan).

Johns Wash Limestone _-- Late Cambrian

Western Utah and eastern Nevada.

Jolliff Member (of Golf Middle Pennsylvanian (late South-central Oklahoma. Course Formation) (of Morrowan).

Dornick Hills Group).

Juab Limestone (of Pogonip Middle Ordovician

Southwestern Utah Group).

Jurassic System (Period) -- Middle Jurassic and Upper

Entire United States (Late) Jurassic (Callovian and Oxfordian).

Kallander Creek Formation Precambrian Y (early Northern Wisconsin and (of Powder Mill Group). Keeweenawan). northwestern Michigan.

Karen Creek Sandstone _- Late Triassic Northeastern Alaska

Karheen Formation Late Silurian to Middle De- Southeastern Alaska vonian (Gedinnian to Eifelian).

Katakturuk Dolomite

Silurian and Early Devo- Northeastern Alaska nian (Gedinnian to Esmian).

Katlian Group

Permian(?) and Triassic(?)_- Southeastern Alaska

Kavik Member (of Ivishak Early Triassic Northeastern Alaska Formation) (of Sadlerochit Group).

Keefer Sandstone (of Clin- Middle Silurian Maryland, Pennsylvania, ton Group).

West Virginia, Ohio, and Kentucky.

Kelp Bay Group Triassic and (or) Jurassic_. Southeastern Alaska

Kemik Sandstone Member Early Cretaceous Northern Alaska (of Okpikruak Formation). 
Joe Creek Member adopted and assigned as lower of two members, to Echooka Formation of Sadlerochit Group (both now raised in rank). Conformably overlies Wahoo Limestone of Lisburne Group; conformably underlies Ikiakpaurak Member (new name) of Echooka. (Detterman and others, 1975.)

Age changed from early Tertiary to: Late Cretaceous or Paleocene. (Tweto, 1974.)

Age changed from Early Pennsylvanian (Morrowan) to Early and Middle Pennsylvanian (Morrowan). (Gordon, this report, p. A54.)

In Confusion and adjacent House Ranges of western Utah, reduced in rank to Johns Wash Limestone Member and assigned to Orr Formation. Underlies Corset Spring Shale Member (also reduced in rank in these areas only). Former usage remains unchanged elsewhere. (Hintze, 1974b.)

Jolliff Limestone Member of Waters (1927) adopted as Jolliff Member as used by Tomlinson (1928) and Harlton (1956); assigned to Golf Course Formation of Dornick Hills Formation. Overlies Primrose Sandstone Member of Golf Course; underlies Otterville Limestone Member of Golf Course. (Gordon, this report, p. A54.)

Juab Limestone or Hintze (1951) adopted and assigned to Pogonip Group. Conformably overlies Wah Wah Limestone and underlies Kanosh Shale, both of Pogonip Group. (Hintze, 1974a.)

Boundary between Middle and Upper (Late) Jurassic Series (Epochs) raised from Bathonian Stage-Callovian Stage to: Callovian Stage-Oxfordian Stage. (Imlay, this report, p. A55.)

Kallander Creek Formation adopted as upper of two formations of Powder Mill Group (new name). Unconformably(?) overlies Siemens Creek Formation (new name) of Powder Mill; unconformably underlies middle Keweenawan(?) nonmagnetic rocks, Portage Lake Volcanics, and Jacobsville Sandstone. Intruded by Mellen Intrusive Complex in Wisconsin and by unnamed diorite in Michigan. (Hubbard, 1975.)

Karen Creek Sandstone adopted. Conformably overlies Shublik Formation; disconformably(?) underlies Kingak Shale. (Detterman and others, 1975.)

Age changed from Late Silurian and Early Devonian to: Late Silurian to Middle Devonian (Gedinnian to Eifelian). (Oliver and others, 1975.)

Age changed from Middle Devonian or older to: Silurian and Early Devonian (Gedinnian to Esmian). (Oliver and others, 1975.)

Katlian Group abandoned; its rocks now included in Kelp Bay Group. (Loney and others, 1975.)

Kavik Member adopted and assigned, as lowermost of three newly named members, to Ivishak Formation of Sadlerochit Group (both now raised in rank). Disconformably and unconformably overlies Ikiakpaurak Member (new name) of Echooka Formation; conformably, underlies Ledge Sandstone Member of Ivishak. (Detterman and others, 1975.)

In south-central Pennsylvania, reduced in rank to Keefer Sandstone Member and assigned to Mifflintown Limestone; Keefer usage remains unchanged elsewhere. (de Witt, 1974.)

Includes (ascending): Goon Dip Greenstone, Whitestripe Marble, Pinnacle Peak Phyllite, Waterfall Greenstone, and Khaz Formation (new). Age changed from Triassic or Jurassic to: Triassic and (or) Jourassic. (Loney and others, 1975.)

Reassigned everywhere to Kongakut Formation (new name), which now replaces Okpikruak Formation (geographically restricted to central and western parts of northern Alaska). (Detterman and others, 1975.) 


\begin{tabular}{lll}
\hline Name & Age & Location \\
\hline
\end{tabular}

Kendall Tuff

Oligocene

South-central Nevada

Kennel Creek Limestone_- Silurian and (or) Devo- Southeastern Alaska nian.

Kessler Limestone Member Middle Pennsylvanian (late Arkansas and Oklahoma-(of Bloyd Formation or Morrowan).

Shale).

Khaz Formation (of Kelp Triassic and (or) Jurassic .- Southeastern Alaska Bay Group).

Kiska Harbor Formation _- late Miocene

Aleutians, southwestern Alaska.

Kodiak Formation

Late Cretaceous

Southern Alaska

Kongakut Formation

Early Cretaceous

Northeastern Alaska

Kootenai Formation

Early Cretaceous

South-central Montana, northwestern Wyoming, and eastern Idaho.

Kreyenhagen Shale or Eocene and Oligocene --.California Formation.

Lake Ardmore Sandstone (of Springer Group).

Early Pennsyl
Morrowan).

Lake Fork Formation

Oligocene

Southwestern Colorado --

Lake Murray Formation (o

Dornick Hills Group).

(Atokan).

Lanes Tongue (of Ankareh Early Triassic Formation).

La Pasada Formation

Early and Mid vanian (Morrowan to Moinesian).

Ledge Sandstone Member Early Triassic Northeastern Alaska (of Ivishak Formation) (of

Sadlerochit Group).

Lemhi Quartzite (of Belt Precambrian Y Supergroup).

Southeastern Idaho and western Wyoming.

North-central New Mex-

East-central Idaho

Lincoln Porphyry

Paleocene

Central Colorado

Lithonia Gneiss

Precambrian(?)

Northwestern Georgia 
Age changed from Oligocene or Miocene to: Oligocene. (Ashley, 1974.)

Age changed from Middle Devonian to: Silurian and (or) Devonian. (Loney and others, 1975.)

Age changed from Early Pennsylvanian (Morrowan) to: Middle Pennsylvanian (Morrowan). (Gordon, this report, p. A54.)

Khaz Formation adopted as uppermost formation of Kelp Bay Group. Overlies Waterfall Greenstone; underlies Sitka Graywacke. (Loney and others, 1975.)

Age changed from late Tertiary or early Pleistocene to: late Miocene. (Scholl and others, 1975.)

Age changed from Cretaceous to: Late Cretaceous. (Beikman, 1975.)

Kongakut Formation adopted; replaces Okpikruak Formation (now geographically restricted to central and western parts of northern Alaska and lower part of Ignek Formation (now abandoned). Includes Kemik Sandstone Member, formerly considered basal member of Okpikruak. Unconformably overlies Ivishak Formation of Sadlerochit Group; conformably underlies Bathtub Graywacke (new name). (Detterman and others, 1975.)

Geographically extended into northwestern Montana, and in that area divided into (ascending): Cut Bank Sandstone, Sunburst Sandstone, and Moulton Members. Kootenai usage elsewhere ramains unchanged. (Rice, this report, p. A66.)

In Devils Den area, Temblor Range, Point of Rocks Sandstone reduced in rank to Point of Rocks Sandstone Member and assigned to Kreyenhagen Formation as middle of three members, overlying its Gredal Shale Member and underlying its Welcome Shale Member. (Maher and others, 1975.)

Lake Ardmore Sandstone Member of Roth (1928) adopted, raised in rank to Lake Ardmore Sandstone, and assigned to Springer Group as uppermost of five named formations. Overlies unnamed shale unit which overlies Rod Club Sandstone of Springer; underlies unnamed shale unit which underlies Golf Course Formation of Dornick Hills Group. (Gordon, this report, p. A54.)

Age changed from Oligocene and older(?) to: Oligocene. (Lipman, 1975.)

Lake Murray Formation of Harlton (1956) adopted and assigned to Dornick Hills Group (now raised in rank). Divided into (ascending): Bostwick Conglomerate Member and Griffin Member. Overlies Golf Coarse Formation of Dornick Hills. (Gordon, this report, p. A54.)

Age changed from Triassic to: Early Triassic. (Rioux and others, 1975.)

La Pasada Formation of Sutherland (1963a, b) and Sutherland and Harlow (1973) adopted. Unconformably overlies Arroyo Penasco Group (Tererro Formation); conformably underlies Alamitos Formation of Sutherland (1963b). (Armstrong and Mamet, 1974.)

Ledge Sandstone Member adopted and assigned, as middle of three newly named members, to Ivishak Formation of Sadlerochit Group (both now raised in rank). Conformably overlies Kavik Member of Ivishak; conformably underlies Fire Creek Siltstone Member of Ivishak. (Detterman and others, 1975.)

Lemhi no longer assigned to Belt Supergroup. Lemhi Quartzite raised in rank to Lemhi Group and divided into (ascending): Inyo Creek, West Fork, and Big Creek Formations (all three new names), Apple Creek Formation, and Gunsight Formation (new name). Age changed from Precambrian to: Precambrian Y. (Ruppel, 1975.)

Age changed from early Tertiary to: Paleocene. (Tweto, 1974.)

Lithonia Granite-Gneiss of Watson (1902) adopted as Lithonia Gneiss as redefined by Herrmann (1954). (Higgins and Zietz, 1975.) 


\begin{tabular}{|c|c|c|}
\hline Name & Age & Location \\
\hline $\begin{array}{l}\text { Little Chief Canyon } \\
\text { Member (of Lodgepole } \\
\text { Limestone) (of Madison } \\
\text { Group). }\end{array}$ & Early Mississippian & Montana \\
\hline $\begin{array}{l}\text { Lodgepole Limestone (of } \\
\text { Madison Group). }\end{array}$ & $\begin{array}{l}\text { Early Mississippian (Kin- } \\
\text { derhookian and Osa. } \\
\text { gean). }\end{array}$ & $\begin{array}{l}\text { Montana, } \\
\text { Idaho. }\end{array}$ \\
\hline Log Springs Formation -- & $\begin{array}{l}\text { Early Mississippian (Ches- } \\
\text { terian). }\end{array}$ & $\begin{array}{l}\text { North-central New Mex- } \\
\text { ico. }\end{array}$ \\
\hline $\begin{array}{l}\text { Logtown Ridge Forma- } \\
\text { tion. }\end{array}$ & Late Jurassic & Central California \\
\hline Lospe Formation & Oligocene & West-central California_- \\
\hline Loyalhanna Limestone & Late Mississippian & $\begin{array}{l}\text { Pennsylvania and Mary- } \\
\text { land. }\end{array}$ \\
\hline $\begin{array}{l}\text { Loyd Sandstone Member (of } \\
\text { Mancos Shale). }\end{array}$ & Late Cretaceous _....... & Northwestern Colorado _-- \\
\hline
\end{tabular}

Macho Member (of Tererro Late Mississippian (Mera- North-central New MexFormation) (of Arroyo mecian). ico.

Penasco Group). Magoffin Member (of Middle Pennsylvanian _-.- Eastern Kentucky -......-
Breathitt Formation).

Mallard Lake Member (of Pleistocene

Plateau Rhyolite).

Malpais Basalt

Miocene or Pliocene

Wyoming

Manakacha Fo Supai Group).

\section{Miocene or Pliocene}

- South-central Nevada -..ormation (of $\mathrm{Mid}$ Middle Pennsylvanian

Northwestern Arizona -.-.Supai Group). (Atokan and Des Moinesian?).

Mancos Shale Late Cretaceous

Colorado, Utah, Arizona, New Mexico, and Wyoming.
Mankomen Formation -..- Early Permian (Sakmarian Eastern Alaska and Artinskian).
Mankomen Formation _..._ Middle Pennsylvanian to Southern Alaska Early Permian.

Manuelitas Member (of Late Mississippian (Mera- North-central New MexTererro Formation) (of mecian). ico. Arroyo Penasco Group).

Marjum Limestone Middle Cambrian Western Utah

Markham Mill Formation Early Pennsylvanian (early Southeastern Oklahoma -(of Jackfork Group). Morrowan). 
Little Chief Canyon Member abandoned; its rocks now included in upper black shale unit of Bakken Formation or in Cottonwood Canyon Member of Lodgepole. (Sando and Dutro, 1974.)

Its lowermost member, Little Chief Canyon, abandoned. Names of its Paine Shale Member and Woodhurst Limestone Member changed to Paine Member and Woodhurst Member, respectively. (Sando and Dutro, 1974.)

Log Springs Formation of Armstrong $(1955,1967)$ adopted. Unconformably overlies Arroyo Penasco Group; unconformably underlies unnamed Pennsylvanian (Morrowan) carbonate rocks. (Armstrong and Mamet, 1974.)

Divided into four new members (ascending): Rabbit Flat, Goat Hill, Pokerville, and New Chicago. (Duffield and Sharp, 1975.)

Age changed from early Miocene(?) to: Oligocene. (Hall, 1974.)

Age changed from Mississippian to: Late Mississippian. (de Witt, 1974.)

Loyd Sandstone Member of Mancos Shale reduced in rank to Loyd Sandstone Bed of Buck Tongue of Mancos Shale in area of this report in northwestern Colorado. Farther east in Colorado where Buck Tongue has merged with main body of Mancos, Loyd remains a member of the Mancos. (Hail, 1974.)

Age changed from Early Mississippian to: Late Mississippian (Meramecian). (Armstrong and Mamet, 1974.)

Magoffin Beds of Morse (1931) adopted and redefined as Magoffin Member and assigned to Breathitt Formation. (Outerbridge, this report, p. A64.)

Age and stratigraphic position changed from oldest and lowermost member of Plateau. As changed, overlies Upper Basin Member of Plateau; underlies Central Plateau Member of Plateau. Christiansen, 1974; Christiansen and Blank, 1974a, b.)

Age changed from Pliocene to: Miocene or Pliocene. (Ashley, 1974.)

Manakacha Formation adopted as one of four formations of Supai Group. Conformably overlies Watahomigi Formation and unconformably underlies Wescogame Formation (both new names of Supai Group). (McKee, 1975.)

In area of this report in northwestern Colorado, Loyd Sandstone Member of Mancos Shale reduced in rank to Loyd Sandstone Bed of Buck Tongue of Mancos Shale. Farther east in Colorado where Buck Tongue has merged with main body of Mancos, Loyd remains member of Mancos. (Hail, 1974.)

Age changed from Permian to: Early Permian (Sakmarian and Artinskian). (Rowett, 1975.)

Raised to group rank and divided into (ascending): Slana Spur and Eagle Creek Formations (new names). Conformably overlies Tetelna Volcanics; disconformably underlies Nikolai Greenstone or intervening unnamed chert and limestone. Age changed from Early Permian to Middle Pennsylvanian to Early Permian. (Richter and Dutro, 1975.)

Age changed from Early Mississippian to: Late Mississippian (Meramecian). (Armstrong and Mamet, 1974.)

Name changed from Marjum Limestone to Marjum Formation everywhere. (Hintz, 1974d.)

Markham Mill Formation of Harlton (1938) adopted as one of five named formations of Jackfork Group. Overlies Prairie Mountain Formation and underlies Wesley Shale, both of Jackfork. (Gordon, this report, p. A54.) 


Name Age $\quad$ Location

Masonic Park Tuff_._._._. Oligocene (28.2 m.y.) _... Southwestern Colorado _.-

McCann Hill Chert

Early(?) to Late Devonian East-central Alaska (Emsian? to Frasnian).

McGowan Creek Forma- Early Mississippian (Kin- East-central Idaho tion derhookian and Osagean).

McKellingon Limestone _. Early Ordovician

Westernmost Texas and southern New Mexico.

McNairy Sand or Forma- Late Cretaceous

Tennessee, Mississippi,. tion or McNairy Sand Missouri, Kentucky, and Member (of Ripley ForIllinois.

mation).

McNeeley Drift late Pleistocene

Washington

Meda Rhyolite middle Miocene

South-central Nevada

Mellen Gabbro Precambrian Y (early Keweenawan?). Northern Wisconsin and northwestern Michigan.

Middendorf Formation Late Cretaceous

North-central South Carolina and south-central North Carolina.

Mifflintown Formation Middle Silurian South-central Pennsylvania.

Millard Member (of Howell Middle Cambrian Western Utah

Limestone).

Molas Formation

Early Pennsylvanian only in report area.

Colorado, New Mexico, and Arizona (sub-surface).

Moleen Formation Early and Middle Pennsyl- Northeastern Nevada vanian (Morrowan and early Atokan).

Moody Shale Member (of late Eocene Northwestern Oregon Toledo Formation).

Mooney Falls Member (of Early and Late Mississip- Arizona Redwall Limestone). pian.

Moorefield Formation _...- Late Mississippian (MeraArkansas and Oklahoma mecian and Chesterian). vanian. Missouri, Nebraska, and Oklahoma. 
Revision and reference

Masonic Park Tuff adopted; formerly mapped as unnamed uppermost tuff unit of Treasure Mountain "Rhyolite" (now "Tuff") by Larsen and Cross (1956) and as tuff of Masonic Park by Lipman and others (1970). Near Mount Hope caldera, interfingers with Sheep Mountain Andesite and other lava units; away from this caldera, generally overlies upper units of Treasure Mountain Tuff; underlies Fish Canyon Tuff, Los Pinos Formation, or Hinsdale Formation. (Lipman, 1975.)

Age changed from Early, Middle(?), and Late Devonian to: Early(?) to Late Devonian (Emsian? to Frasnian). (Oliver and others, 1975.)

McGowan Creek Formation adopted. Unconformably overlies Three Forks Formation; grades into Middle Canyon Formation. (Sandberg, 1975.)

McKellingon Formation of Flower (1964) adopted as McKelligon Limestone, middle of three formations assigned to El Paso Group (raised to group rank in westernmost Texas and southern New Mexico). Overlies Hitt Canyon Formation and underlies Padre Formation (both new names). (Hayes, 1975.)

In western Tennessee, raised in rank to McNairy Sand; Ripley Formation geographically restricted from Tennessee. McNairy usage remains unchanged elsewhere. (Parks and Russell, 1975.)

In Mount Rainier region, assigned to Sumas Stade in Fraser Glaciation. (Crandell and Miller, 1974.)

Age changed from Oligocene or Miocene to: middle Miocene. (Ashley, 1974.)

Name changed from Mellen Gabbro to Mellen Intrusive Complex. Age changed from late Precambrian (middle Keweenawan) to: Precambrian Y (early Keweenawan?). (Hubbard, 1975.)

Middendorf Formation reinstated, as it is still considered good usage in South Carolina and North Carolina. (Bell and others, 1974.)

Name changed to Mifflintown Limestone, and Keefer Sandstone Member assigned to Mifflintown as its lowermost member. (de Witt, 1974).

Millard Limestone of Wheeler (1948) adopted as Millard Member, basal member of Howell Limestone. Conformably overlies Tatow Formation; conformably underlies unnamed upper member of Howell Limestone. (Hintze, 1974d.)

Geographically extended into south-central Utah subsurface. (Peterson and Barnum, $1973 \mathrm{a}, \mathrm{b}$.)

Moleen Formation of Dott (1955) adopted. Overlies Diamond Peak Formation; underlies Tomera Formation. (Smith and Ketner, 1975.)

Moody Shale Member of Toledo Formation abandoned (both names); its rocks now assigned to (ascending) Yamhill and Nestucca Formations (now geographically extended into Oregon Coast Range, northwestern Oregon). (Snavely and others, 1975.)

Geographically extended into south-central Utah subsurface. (Peterson and Barnum, $1973 \mathrm{a}, \mathrm{b}$.

In north-central Ozark region, divided into (ascending): Spring Creek Member (now reinstated and reduced in rank from Spring Creek Limestone; Meramecian and Chesterian in age) and Ruddell Shale Member (now reduced in rank from Ruddell Shale; Chesterian in age). Moorefield remains unchanged elsewhere. When divided into two members, age changed from Late Mississippian (Meramecian) to: Late Mississippian (Meramecian and Chesterian). (Gordon, this report, p. A54.)

Age changed from Early Pennsylvanian to: Early and Middle Pennsylvanian. (Gordon, this report, p. A54.) 


\begin{tabular}{lll}
\hline Name & Age & Location \\
\hline
\end{tabular}

Mosby Sandstone Member Late Cretaceous

Montana (of Warm Creek Shale).

Moulton Member (of Early Cretaceous

Northwestern Montana -Kootenai Formation).

Mount Pisgah Formation Ordovician(?) to Early 'De- Northeast-central Connec(of Brimfield Group). vonian(?). ticut and adjacent Massachusetts.

Mount Princeton Quartz Eocene(?) to Oligocene(?) _- Colorado Monzonite.

Moyers Formation or Late Mississippian (Cheste- Eastern Oklahoma and Moyers Member (of Stan- rian). western Arkansas.

ley Group or of Stanley Shale).

Muav Limestone i $\wedge^{f}$ Tonto Middle Cambrian Arizona and Nevada Group).

Muddy Sandstone Mem :er Late Cretaceous Wyoming and Montana -(of Thermopolis Shale).

Nakwasina Group Permian(?) and Triassic(?)_- Southeastern Alaska

Nanook Limestone Middle(?) Devonian (Eife- Northeastern Alaska lian? and Givetian?).

Nassau Formation Late Precambrian(?) and New York (or) Early Cambrian(?).

Needles Range Formation_- Oligocene Southwestern Utah and eastern Nevada.

Needmore Shale

Early and Middle Devo- Pennsylvania, Maryland, nian. and West Virginia.

Nestucca Formation late Eocene Northwestern Oregon

New Chicago Member (of Late Jurassic Central California Logtown Ridge Formation).

New Creek Limestone Early Devonian

Southwestern Pennsylvania, northern West Virginia, and western Maryland.

Northumberland Tuff Oligocene Central Nevada

Notch Peak Limestone Late Cambrian and Early Western Utah and eastern Ordovician. Nevada. 
Warm Creek Shale abandoned; Mosby reassigned to Greenhorn Formation (nor geographically extended into north-central and central Montana). (Rice, this report, p. A66.)

Moulton sand (economic term) adopted as Moulton Member of Kootenai Formation as defined by Oakes (1966). Uppermost member of Kootenai; overlies Sunburst Sandstone Member of Kootenai. (Rice, this report, p. A66.)

Mount Pisgah Formation adopted and assigned to Brimfield Group (now raised in rank in northeast-central Connecticut and adjacent Massachusetts between Bonemill Brook and Eastford faults). Uppermost of three formations assigned to Brimfield Group; overlies Hamilton Reservoir Formation (new name). (Peper and others, 1975.)

Age changed from Paleocene(?) to Oligocene(?) to: Eocene(?) to Oligocene(?). (Scott and others, this report, p. A67.)

Moyers Formation of Harlton (1938) adopted and assigned to Stanley Group in eastern Oklahoma; Moyers reduced in rank to Moyers Member or its equivalent of Stanley Shale in western Arkansas. Overlies Tenmile Creek Formation/Member; underlies Chickasaw Creek Shale/Member. (Gordon, this report, p. A54.)

Geographically extended into south-central Utah in the subsurface. (Peterson and Barnum, 1973a, b.)

In Montana and, by geographic extension, in North and South Dakota, Muddy Sandstone Member raised to formation rank as Muddy Sandstone. Thermopolis Shale geographically restricted from Montana; Muddy Sandstone Member of Thermopolis Shale remains in good usage in Wyoming. (Rice, this report, p. A66.)

Nakwasina Group abandoned; term is synonym for term Kelp Bay Group as used in report area. (Loney and others, 1975.)

Age changed from Middle Devonian to: Middle(?) Devonian (Eifelian?-Givetian?). (Oliver and others, 1975.)

Rensselaer(?) Graywacke tentatively included as member of Nassau in report area. Age changed from Early Cambrian to: late Precambrian(?) and (or) Early Cambrian(?). (Ratcliffe, 1974a.)

In southwestern Utah only. Cottonwood Wash Tuff Member adopted as lower member of Needles Range Formation. Conformably underlies its Wah Wah Springs Tuff Member. (Hintze, 1974a.)

Tioga Bentonite Bed geographically extended into south-central Pennsylvania and reassigned to Needmore Shale as Tioga Metabentonite Bed. Needmore age changed from Middle Devonian to: Early and Middle Devonian. (de Witt, 1974.)

Geographically extended into Oregon Coast Range, replacing middle part of Toledo Formation (upper part of its Moody Shale Member) (both names now abandoned). Overlies Yamhill Formation and underlies Alsea Formation (new name), which replace lower and upper parts of Toledo Formation, respectively. (Snavely and others, 1975.)

New Chicago Member adopted as uppermost of four new members of Logtown Ridge Formation; conformably overlies Pokerville Member. (Duffield and Sharp, 1975.)

New Creek Limestone of Bowen $(1966,1967)$ adopted. Overlies Keyser Limestone; underlies Corriganville Limestone of Head (1968). (de Witt, 1974.)

Northumberland Tuff adopted. Overlies Paleozoic basement rocks; underlies tuff of Hoodoo Canyon. (McKee, 1974.)

Name changed from Notch Peak Limestone to Notch Peak Formation. Age changed from Late Cambrian to: Late Cambrian and Early Ordovician. (Hintze, 1974d.) 


\begin{tabular}{ccc}
\hline Name & Age & Location \\
\hline
\end{tabular}

Nuwok Member (of Saga- Miocene(?) and Pliocene _- Northeastern Alaska vanirktok Formation).

Ocoee Series

Okpikruak Formation

Onate Formation

Oro Grande Formation

Orr Formation

Otterville Limestone

Overbrook Sandstone (of Springer Group).
Precambrian

Early Cretaceous

Georgia, Tennessee, North

Carolina, and Virginia.

Northern Alaska

late Middle Devonian

South-central New Mexico.

Precambrian $\mathrm{Z}$ and Cam- Southern California brian.

Late Cambrian

Western Utah

Middle Pennsylvanian South-central Oklahoma -(Morrowan).

Late Mississippian (Ches- South-central Oklahoma -terian).

Padre Formation (of E1 Paso Early Ordovician

Westernmost Texas and southern New Mexico.

Paine Shale Member (of Early Mississippian (Kin- Montana, Wyoming, and Lodgepole Limestone) (of derhookian). Idaho. Madison Group).

Pauite Ridge Member (of Middle Ordovician

Southern Nevada Antelope Valley Limestone).

Pando Porphyry

Late Cretaceous

Central Colorado

Peasley Member (of High- Middle Cambrian Southeastern Nevada land Peak Limestone)

Pend Oreille Andesite

Eocene

Northeastern Washington_-

Phillips Lake Granodio- Cretaceous

Northeastern Washington.

Picabo Formation

Late Devonian

Central Idaho

Pinehurst Formation late Miocene or Pliocen

South-central North Carolina.

Plateau Rhyolite

Pleistocene oming. 
Nuwok Formation of Dall $(1919,1920)$ adopted as Nuwok Member, uppermost of three members of Sagavanirktok Formation. Conformably overlies Franklin Bluffs Member (new name) of Sagavanirktok; underlies Gubik Formation. (Detterman and others, 1975.)

Name and rank changed to Ocoee Supergroup. (Higgins and Zietz, 1975.)

Geographically restricted from northeastern Alaska; presently valid only in central and western parts of northern Alaska. Its rocks now included in lower part of Kongakut Formation (new name), to which its Kemik Sandstone Member is now reassigned. (Detterman and others, 1975.)

Onate Formation of Stevenson (1945) adopted as redefined by Flower (1965). Unconformably overlies Silurian and Ordovician strata; underlies Sly Gap Formation. (Cooper and Dutro, 1974.)

Overall age changed from Carboniferous(?) to: Precambrian $\mathrm{Z}$ to Permian(?) (varies locally). (Stewart and Poole, 1975.)

In Confusion and adjacent House Ranges, includes (ascending): Johns Wash Limestone Member and Corset Spring Shale Member (both reduced from formational rank in these areas only; former usage remains unchanged elsewhere). (Hintze, 1974b.)

Reduced in rank to Otterville Limestone Member and assigned to Golf Course Formation of Dornick Hills Group as used by Harlton (1956). Overlies Jolliff Member of Golf Course; underlies Bostwick Conglomerate Member of Lake Murray Formation. (Gordon, this report, p. A54.1

Overbrook Sandstone Member of Roth (1928) adopted, raised in rank to Overbrook Sandstone, and assigned to Springer Group as one of five named formations. Overlies Goddard Shale of Springer (and its upper shale member); underlies Rod Club Sandstone of Springer. (Gordon, this report, p. A54.)

Padre Formation adopted as uppermost of three formations assigned to El Paso Group (raised to group rank in westernmost Texas and southern New Mexico); overlies McKelligon Limestone (newly adopted of Flower, 1964). (Hayes, 1975.)

Name changed from Paine Shale Member to Paine Member. (Sando and Dutro, 1974.)

Age changed from Early and Middle Ordovician to: Middle Ordovician. (Ross and others, 1975.)

Age changed from early Tertiary to: Late Cretaceous. (Tweto, 1974.)

Geographically extended into southwestern Utah and raised in rank to Peasley Limestone. Former usage remains unchanged elsewhere. (Hintze, 1974e.)

Pend Oreille Andesite of Schroeder (1952) adopted and restricted to northeastern part of map area. (Miller, 1974a.)

Phillips Lake Granodiorite adopted. Unconformably overlies Wallace Formation, Ravalli Group, and Prichard Formation; unconformably underlies Quaternary glacial, alluvial and talus deposits. (Miller and Clark, 1975.)

Picabo Formation adopted. Overlies Jefferson Formation; underlies Copper Basin Formation. (Skipp and Sandberg, 1975.)

Pinehurst Formation of Conley (1962) adopted as redefined by Bartlett (1967). (Bell and others, 1974.)

Shoshone Lake Tuff Member of Plateau abandoned; its rocks now included in unnamed tuffs of Cold Mountain Creek and Bluff Point. Mallard Lake Member of Plateau now known to be younger than Upper Basin Member of Plateau. Plateau now divided into (ascending): Obsidian Creek, Roaring Mountain, Upper Basin, Mallard Lake, and Central Plateau Members (and its unnamed tuffs of Cold Mountain Creek and Bluff Point). (Christiansen, 1974, 1975; Christiansen and Blank, 1974a, b.) 


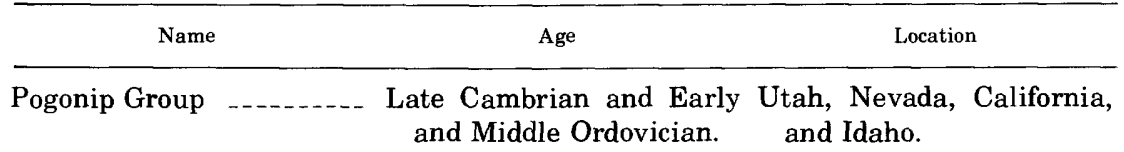

Point Augusta Formation._ Late(?) Silurian Southeastern Alaska

Point of Rocks Sandstone_- middle and late Eocene _.. Southern California

Pokerville Member (of Log- Late Jurassic (Callovian)__ Central California town Ridge Formation).

Port Refugio Formation _- Middle and Late Devonian Southeastern Alaska (Givetian to Famennian) and Mississippian.

Powder Mill Group

Precambrian Y (early Kee- Northern Wisconsin and weenawan). northwestern Michigan.

Pozo Formation

Miocene South-central Nevada

Prairie Mountain Formation (of Jackfork Group).

y Pennsylvanian (early Southeastern Oklahoma -. Morrowan).

Primrose Sandstone Mem- Early Pennsylvanian (early South-central Oklahoma -ber (of Golf Course For- Morrowan). mation) (of Dornick Hills Group).

Pumpernickel Formation _- Early Pennsylvanian to Northern Nevada

Pybus Formation Early Permian

Early Permian (Kungu- Southeastern Alaska rian).

Rabbit Flat Member (of Late Jurassic Central California Logtown Ridge Formation).

Rabbit Spring Formation_- Miocene or Pliocene South-central Nevada

Ranger Mountains Member Middle Ordovician Southern Nevada (of Antelope Valley Limestone).

Ready Bullion Formation_- Holocene east-central Alaska

Redoak Hollow Member (of Late Mississippian (Cheste- South-central Oklahoma -Goddard Shale) (of rian). Springer Group).

Redrock Valley Tuff Miocene Southern Nevada 
Revision and reference

In eastern Confusion Range, southwestern Utah, Pogonip divided into (ascending): House Limestone, Fillmore Formation, Wah Wah Limestone, Juab Limestone, Kanosh Shale, and Lehman Formation. Age is Early and Middle Ordovician only in this report area. (Hintze, 1974c.)

Point Augusta Formation adopted as oldest stratified unit in report area; underlies Kennel Creek Limestone. (Loney and others, 1975.)

Reduced in rank to Point of Rocks Sandstone Member and assigned to Kreyenhagen Formation as middle of three members in Devils Den area. Overlies Gredal Shale Member and underlies Welcome Shale Member, both of Kreyenhagen. (Maher and others, 1975.)

Pokerville Member adopted as uppermost of three new members of Logtown Ridge Formation except east and southeast of Drytown where it underlies fourth new member, New Chicago Member; conformably overlies Goat Hill Member. (Duffield and Sharp, 1975.)

Age changed from Late Devonian to: Middle and Late Devonian (Givetian to Famennian) and Mississippian. (Oliver and others, 1975.)

Powder Mill Group adopted and divided into (ascending): Siemens Creek and Kallander Creek Formations (both new names). Conformably overlies Bessemer Quartzite; unconformably underlies middle Keweenawan(?) nonmagnetic rocks, Portage Lake Volcanics, and Jacobsville Sandstone. Intruded by Mellen Intrusive Complex in Wisconsin and by unnamed diorite in Michigan. (Hubbard, 1975.)

Age changed from Pliocene to: Miocene. (Ashley, 1974.)

Prairie Mountain Formation of Harlton (1938) adopted as one of five named formations of Jackfork Group. Overlies Wildhorse Mountain Formation and underlies Markham Mill Formation, both of Jackfork. (Gordon, this report, p. A54.)

Primrose Sandstone series of Roth (1928) adopted as Primrose Sandstone Member of Golf Course Formation of Dornick Hills Group as used by Harlton (1956). Overlies Lake Ardmore Sandstone; underlies Gene Autry Member of Golf Course, Divided into unnamed lower and upper parts. (Gordon, this report, p. A54.)

Age changed from Pennsylvanian(?) to: Early Pennsylvanian to Early Permian. (Erickson and Marsh, 1974.)

Age changed from Permian to: Early Permian (Kungurian). (Rowett, 1975.)

Rabbit Flat Member adopted as lowermost of four new members of Logtown Ridge Formation; conformably underlies Goat Hill Member. (Duffield and Sharp, 1975.)

Age changed from Pliocene or Pleistocene to: Miocene or Pliocene. (Ashley, 1974.)

Age changed from Early and Middle Ordovician to: Middle Ordovician. (Ross and others, 1975.)

Ready Bullion Formation adopted. Unconformably overlies Goldstream Formation (new name); grades laterally into and is equivalent of Engineer Loess (new name). (Péwé, 1975a.)

Redoak Hollow Sandstone Member of Elias (1956) adopted as Redoak Hollow Member and assigned as middle of three members of Goddard Shale of Springer Group. Overlies unnamed lower shale member of Goddard; underlies unnamed upper shale member of Goddard. (Gordon, this report, p. A54.)

Indian Trail Formation abandoned. Its rocks now included in (ascending): Fraction Tuff, Redrock Valley Tuff, and Crater Flat Tuff (all three now geographically extended). Indian Trail's two members (ascending)_Tub Spring and Grouse Canyon-now geographically restricted to area of reassignment to Belted Range Tuff. (Dixon and others, this report, p. A49.) 


$\begin{gathered}\text { Name } \\ \text { Redwall Limestone }\end{gathered}-\begin{gathered}\text { Ege } \\ \text { pianly and Late Mississip- Arizona } \\ \text { ico. }\end{gathered}$ and New Mex-

Rensselaer Graywacke _... late Precambrian(?) and (or) New York and Vermont _Early Cambrian(?).

Rhoda Creek Formation -. Late Mississippian (Ches- South-central Oklahoma -terian).

Ripley Formation (of Selma Late Cretaceous Mississippi, Alabama, Group in Alabama and Georgia, and Tennessee.

Mississippi only).

Road River Formation ..... Silurian to Early Devonian East-central Alaska (Gedinnian to Emsian?).

Roberts Mountains Forma- Early Silurian to Early De- North-central Nevada tion. vonian.

Rod Club Sandstone (of Late Mississippian (Ches- South-central Oklahoma -Springer Group). terian).

Rosita Formation Oligocene South-central Colorado

Ruddell Shale Late Mississippian (Ches- Arkansas terian).

Sacramento Porphyry .... Late Cretaceous or Paleo- Central Colorado cene.

Sadlerochit Formation -...- Late Early Permian to Northeastern Alaska Early Triassic.

Sagavanirktok Formation.. Paleocene to Pliocene _...- Northern Alaska

Sagwon Member (of Saga- Paleocene and Eocene _...- Northeastern Alaska vanirktok Formation).

Salmon Springs Glaciation late Pleistocene Washington or Drift.

Salmontrout Limestone _- Early or Middle Devonian Northeastern Alaska -..(Emsian or Eifelian).

Sand Branch Member (of Late Mississippian (Ches- South-central Oklahoma.. Caney Shale). terian).

Sandstorm Formation San Jose Formation Oligocene early Eocene

San Juan Formation or Oligocene Breccia.

Santos Shale member (of Oligocene and Miocene_- Southern California
South-central Nevada

New Mexico

Southwestern Colorado --

Temblor Formation). 
Revision and reference

Redwall Limestone and its four members (ascending)-Whitmore Wash, Thunder Springs, Mooney Falls, and Horseshoe Mesa-geographically extended into southcentral Utah subsurface. (Peterson and Barnum, 1973a, b.)

Rensselaer(?) Graywacke tentatively included as member of Nassau Formation in report area. Age changed from Early Cambrian(?) to: late Precambrian(?) and (or) Early Cambrian(?). (Ratcliffe, 1974a.)

Rhoda Creek Formation of Elias (1955) adopted. Overlies Sand Branch Member of Caney Shale; underlies unnamed shale interval which underlies Union Valley Formation. (Gordon, this report, p. A54.)

Geographically restricted from Tennessee; in western Tennessee, its Coon Creek Tongue and its McNairy Sand Member raised to formational rank. (Parks and Russell, 1975.)

Age changed from Early Ordovician to Early Devonian to: Silurian to Early Devonian (Gedinnian to Emsian?). (Oliver and others, 1975.)

Geographically extended into south-central Idaho, where age is Late Silurian and Early Devonian only. (Skipp and Hall, 1975.)

Rod Club Sandstone Member of Tomlinson (1928) adopted, raised in rank to Rod Club Sandstone, and assigned to Springer Group as one of five named formations. Overlies Overbrook Sandstone of Springer; underlies unnamed shale unit which underlies Lake Ardmore Sandstone of Springer. (Gordon, this report, p. A54.)

Name changed from Rosita Formation (a redefinition) back to Rosita Andesite (a reinstatement, adhering to original definition.) (Scott and Taylor, 1975.)

Reduced in rank to Ruddell Shale Member and assigned to Moorefield Formation as upper of two members. Overlies Spring Creek Member of Moorefield; underlies Batesville Sandstone. (Gordon, this report, p. A54.)

Age changed from early Tertiary to: Late Cretaceous or Paleocene. (Tweto, 1974.)

Raised in rank to Sadlerochit Group and divided into (ascending): Echooka and Ivishak Formations (both raised from member rank) and their member subdivisions. (Detterman and others, 1975.)

Stratigraphically extended to include all rocks above Kogosukruk Tongue of Prince Creek Formation and below Gubik Formation. Divided into (ascending): Sagowon, Franklin Bluffs (both new names), and Nuwok Members. Age changed from Oligocene(?) to: Paleocene to Pliocene. (Detterman and others, 1975.)

Sagwon Member adopted as lowermost of three members of Sagavanirktok Formation. Conformably overlies Kogosukruk Tongue of Prince Creek Formation; conformably(?) underlies Franklin Bluffs Member (new name) of Sagavanirktok. (Detterman and others, 1975.)

Salmon Springs Glaciation includes (ascending): Wingate Hill Drift (tentatively) and Hayden Creek Drift. (Crandell and Miller, 1974.)

Age changed from Early Devonian to: Early or Middle Devonian (Emsian or Eifelian). (Oliver and others, 1975.)

Sand Branch Member of Elias (1956) adopted as uppermost of three members of Caney Shale. Overlies Delaware Creek Member of Caney; underlies Rhoda Creek Formation. (Gordon, this report, p. A54.)

Age changed from Oligocene or Miocene to: Oligocene. (Ashley, 1974.)

Geographically extended into southwestern Colorado from New Mexico. (Hampton, 1974.1

Age changed from Oligocene and older(?) to: Oligocene. (Lipman, 1975.)

Agua Sandstone Member reduced in rank to Agua Sandstone Bed and reassigned to Santos Shale Member of Temblor Formation. (Maher and others, 1975.) 


\begin{tabular}{lll}
\hline Name & Age & Location \\
\hline
\end{tabular}

Saragossa Quartzite

Precambrian $\mathrm{Z}$ and Early Southern California Cambrian.

Sardis Formation

Late Cretaceous

Western Tennessee

Saturday Mountain Forma- Middle and Late Ordovi- Idaho tion.

Scherr Formation cian. Late Devonian

Southwestern Pennsylvania and northern West Virginia.

Seabee Formation (of Col- Late Cretaceous Northern Alaska ville Group).

Second Value Dolomite _- Middle and Late Ordovi- Southern New Mexico and cian. southeastern Arizona.

Sheep Mountain Forma- Oligocene Southwestern Colorado.tion.

Shelikof Formation

Shoshone Lake

Middle Jurassic

Southern Alaska

Member (of Plateau

Rhyolite).

Shriver Chert (of Oriskany Early Devonian Group).

Siamo Slate (of Menominee Precambrian Y(?)

Maryland, West Virginia, and Pennsylvania. Group) (of Marquette Range Supergroup).

Siemens Creek Formation Precambrian Y (early Ke- Northern Wisconsin and (of Powder Mill Group). weenawan). northwestern Michigan.

Silver Point Quartz Monzo- Eocene Northeastern Washington.nite.

Skajit Limestone (of Baird Silurian to Late Devonian Northern Alaska Group). (Gedinnian to Frasnian).

Skolai Group

Early Permian (Sakmarian Southeastern Alaska and Artinskian).

Slana Spur Formation (of Middle Pennsylvanian to Southern Alaska Mankomen Group). Early Permian.

Sly Cap Formation early Late Devonian (Fras- South-central New Mexnian). ico.

Snake River Group Pleistocene and Holocene -_ $_{\text {S }}$ Southern Idaho

Snowbird Group (of Ocoee Precambrian North Carolina and TenSeries).

Spearhead Member (of Miocene or Pliocene nessee.

South-central Nevada Thirsty Canyon Tuff).

Spring Creek Limestone_- Late Mississippian (Mera- Arkansas mecian and Chesterian). 
Age changed from Paleozoic to: Precambrian $\mathrm{Z}$ and Early Cambrian. (Stewart and Poole, 1975.)

Sardis Formation of Russell (1966) adopted. Overlies Coffee Sand and underlies Demopolis Formation. (Parks and Russell, 1975.)

Age changed from Middle Ordovician and younger to: Middle and Late Ordovician. (Dover and Ross, 1975.)

Scherr Formation of Dennison (1970) adopted. Overlies Brallier Formation; underlies Foreknobs Formation (not new). (de Witt, 1974.)

Geographically extended into northeastern Alaska, replacing upper part of Ignek Formation (now abandoned). (Detterman and others, 1975.)

Geographically extended into westernmost Texas. Age changed from Middle and Late Ordovician to: Middle Ordovician. (Hayes, 1975.)

Name changed from Sheep Mountain Formation to Sheep Mountain Andesite. Geographically restricted to andesites near type locality that are penecontemporaneous with Masonic Peak Tuff (new name); stratigraphically equivalent to Summitville Andesite (newly reinstated). (Lipman, 1975.)

Age changed from Late Jurassic to: Middle Jurassic. (Beikman, 1975.)

Shoshone Lake Tuff Member of Plateau abandoned; its rocks now included in unnamed tuffs of Cold Mountain Creek (Old Faithful quadrangle) and Bluff Point (Norris Junction quadrangle) and assigned to Central Plateau Member, uppermost member of Plateau. (Christiansen and Blank, 1974.)

In south-central Pennsylvania, name changed to Shriver Formation; name remains Shriver Chert elsewhere. (de Witt, 1974.)

Goose Lake Member of Tyler and Twenhofel (1952) adopted as member of Siamo Slate. (Gair, 1975.)

Siemens Creek Formation adopted as lower of two formations of Powder Mill Group (new name). Conformably overlies Bessemer Quartzite; unconformably(?) underlies Kallander Creek Formation (new name) of Powder Mill. Intruded by Mellen Intrusive Complex in Wisconsin and by unnamed diorite in Michigan. (Hubbard, 1975.)

Age changed from Tertiary to: Eocene. (Engels, 1975.)

In northwestern Alaska, age changed from Middle(?) and Late Devonian to: Silurian to Late Devonian (Gedinnian to Frasnian); in north-central Alaska, age is Early to Late Devonian (Siegenian? to Frasnian). (Oliver and others, 1975.)

Age changed from Early Permian(?) and Early Permian to: Early Permian (Sakmarian and Artinskian). (Rowett, 1975.)

Slana Spur Formation adopted as lower of two formtions in Mankomen Group (newly raised in rank). Conformably overlies Tetelna Volcanics; conformably underlies Eagle Creek Formation (new name) of Mankomen. (Richter and Dutro, 1975.)

Sly Gap Formation of Stevenson (1945) adopted as redefined by Flower (1965). Overlies Onate Formation; underlies Percha Shale. (Cooper and Dutro, 1974.)

In southeastern Idaho only, Cedar Butte Basalt assigned to Snake River Group as well as Big Hole Basalt of former usage. (Crosthwaite, 1974.)

Geographically extended into northern Georgia. Changed from subdivision of Ocoee Series to subdivision of Ocoee Supergroup. (Higgins and Zietz, 1975.)

Age changed from Pliocene to: Miocene or Pliocene. (Ashley, 1974.)

Reinstated and reduced in rank to Spring Creek Member; assigned to Moorefield Formation as lower of two members. Overlies Boone Formation; underlies Ruddell Shale Member of Moorefield. Age changed from Mississippian to: Late Mississippian (Meramecian and Chesterian). (Gordon, this report, p. A54.) 


\begin{tabular}{ccc}
\hline Name & \multicolumn{1}{c}{ Age Location } \\
\hline Springer Formation $\ldots \ldots-$ & $\begin{array}{l}\text { Late Mississippian and South-central Oklahoma }-- \\
\text { Early Pennsylvanian } \\
\text { (Chesterian and Morro- } \\
\text { wan). }\end{array}$
\end{tabular}
Staniukovich Formation_- Late Jurassic and Early Southwestern Alaska -..- Cretaceous (upper half-Berriasian and Valanginian).

Stanley Shale Late Mississippian (Mera- Oklahoma and Arkansas _mecian and Chesterian).

Starvation Flat Quartz Cretaceous Northeastern Washing. Monzonite. ton.

Station Creek Formation (of Early Permian (Sakmarian Southeastern Alaska

Skolai Group).

Step Conglomerate and Artinskian).

Early Permian (Artinskian East-central Alaska and Kungurian).

Stockbridge Formation Early Cambrian to Early New York or Limestone Ordovician.

Strathearn Formation _- Late Pennsylvanian and Northeastern Nevada Early Permian (Missourian, Virgilian, and Wolfcampian).

Sumas Stade (of Fraser late Pleistocene Glaciation).

Summerhouse Formation_- Early Ordovician East-central Idaho

Summitville Andesite_. Oligocene Southwestern Colorado

Sunburst Sandstone Early Cretaceous Northwestern Montana

Formation).

Sundance Formation

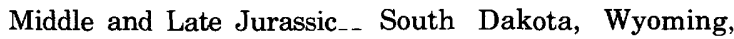
Nebraska, Montana, and Colorado.

Sunshine Peak Rhyolite_-- Oligocene Southwestern Colorado --

Supai Formation (of Aubrey Early, Middle, and Late Group).

Pennsylvanian and Early Permian (age varies by location).
Arizona, Utah, New Mexico, Nevada, and California. 
Raised in rank to Springer Group. Divided into (ascending): Caney Shale (and its Delaware Creek Member), Goddard Shale (and its lower shale, Redoak Hollow, and upper shale members), Overbrook Sandstone, Rod Club Sandstone, unnamed shale unit, Lake Ardmore Sandstone, and another unnamed shale unit. Overlies Sycamore Limestone; underlies Dornick Hills Group. Age changed from Mississippian and Pennsylvanian to: Late Mississippian and Early Pennsylvanian (Chesterian and Morrowan). (Gordon, this report, p. A54.)

Age changed from Late Jurassic to: Late Jurassic and Early Triassic (upper halfBerriasian and Valanginian). (Jones, 1973.)

In eastern Oklahoma, Stanley Shale raised in rank to Stanley Group and divided into (ascending): Tenmile Creek Formation, Moyers Formation, and Chickasaw Creek Shale. In western Arkansas, Stanley remains Stanley Shale and divided into (ascending): Tenmile Creek, Moyers, and Chickasaw Creek Members or their equivalents. Age changed from Mississippian to: Late Mississippian (Meramecian and Chesterian). (Gordon, this report, p. A54.)

Age changed from Mesozoic(?) to: Cretaceous. (Engels, 1975.)

Age changed from Early Permian(?) to: Early Permian (Sakmarian and Artinskian). (Rowett, 1975.)

Age changed from Permian to: Early Permian (Artinskian and Kungurian). (Rowett, 1975.)

Age changed from Early Cambrian to Early or Middle Ordovician to: Early Cambrian to Early Ordovician. (Ratcliffe, 1974a.)

Strathearn Formation of Dott (1955) adopted. Overlies Diamond Peak Formation; underlies unnamed Permian rocks. (Smith and Ketner, 1975.)

In Mount Rainier region, McNeeley Drift assigned to Sumas Stade in Fraser Glaciation. (Crandell and Miller, 1974.)

Summerhouse Formation adopted. Overlies Swauger Formation or Wilbert Formation (new name); underlies Kinnikinic Quartzite. (Ruppel and others, 1975.)

Reinstated and confined to area in and near Platoro caldera complex; stratigraphically equivalent to Sheep Mountain Andesite. (Lipman, 1975.)

Sunburst sand (economic term) adopted as Sunburst Sandstone Member of Kootenai Formation. Sunburst Sandstone Member formerly defined by Oakes (1966) for his Lander members (preempted name). Overlies Cut Bank Sandstone Member of Kootenai; underlies Moulton Member of Kootenai. (Rice, this report, p. A66.)

Age changed from Late Jurassic to: Middle and Late Jurassic. (Love and Keefer, 1975.)

Name changed from Sunshine Peak Rhyolite to Sunshine Peak Tuff, (Steven and others, 1974.)

In northwestern Arizona only, Supai Formation raised in rank to Supai Group; Supai Formation remains in good usage elsewhere. Divided into (ascending): Watahomigi Formation (new name; Morrowan and Atokan), Manakacha Formation (new name; Atokan and Des Moinesian?), Wescogame Formation (new name; Virgilian), and Esplanade Sandstone (now raised in rank from member status; Wolfcampian). Unconformably overlies Redwall Limestone; unconformably underlies Hermit Shale. (McKee, 1975.) 


\begin{tabular}{lll}
\hline Name & Age & Location \\
\hline
\end{tabular}

Swarbrick Formation

Swasey Formation

Swauger Quartzite

Tanana Formation

Tapeats Sandstone (of Ea Tonto Group).

Tatow Formation

Tea Cup Granodiorite

Tenmile Creek Formation or Tenmile Creek Member (of Stanley Group or of Stanley Shale).

Tererro Formation

Tetelna Volcanics

Thermopolis Shale

Thirsty Canyon Tuff Thunder Springs Member (of Redwall Limestone).

Tiger Formation Tertiary

Pennsylvanian Early Cretaceous Southern Alaska Wyoming and Montana --
Western Utah

East-central Idaho
Late Mississippian (Mera- North-central New Mexmecian and Chesterian). ico.
California.

Western Utah

Southeastern Arizona

Eastern Oklahoma and western Arkansas.

Tioga Bentonite Bed (of Middle Devonian Seneca Member) (of Onondaga Limestone).

Toledo Formation

late Eocene and Oligo- Northwestern Oregon cene.

Tolovana Limestone

Early(?) Silurian to Middle Devonian (Llandoverian? to Givetian?).

Tombigbee Sand Member Late Cretaceous (of Eutaw Formation).

Tomera Formation

Middle Pennsylvanian Northeastern Nevada (early Atokan to early Des Moinesian).

Toro Formation Late Jurassic and Early West-central California -. Cretaceous. 
Revision and reference

Age changed from Cambrian to: Middle(?) and Upper Cambrian. (Quinlivan and Rogers, 1974.)

Name changed from Swasey Formation to Swasey Limestone. (Hintze, 1974e.)

Swauger no longer assigned to Belt Supergroup. Name changed from Swauger Quartzite to Swauger Formation. Age changed from Precambrian to: Precambrian Y. (Ruppel, 1975.)

Tanana Formation adopted. Overlies bedrock; underlies Fairbanks or Gold Hill (new name Loess; in valley bottoms, grades laterally into Fox Gravel (new name). (Péwé, 1975a.)

Geographically extended into south-central Utah subsurface. (Peterson and Barnum, 1973a, b.)

Tatow Limestone of Deiss (1938) adopted as Tatow Formation. Conformably overlies Pioche Formation; underlies Howell Limestone. (Hintze, 1974d.)

Tea Cup Granodiorite adopted. Intrudes Ruin Granite and Pinal Schist; intruded by Paleocene and younger Tertiary dikes. (Cornwall and Krieger, 197.5.)

Tenmile Creek Formation of Harlton (1938) adopted and assigned to Stanley Group in eastern Oklahoma; Tenmile Creek reduced in rank to Tenmile Creek Member or its equivalent of Stanley Shale in western Arkansas. Overlies unknown rocks; underlies Moyers Formation/Member. (Gordon, this report, p. A54.)

Assigned to Arroyo Penasco Group (newly raised in rank) as upper of two formations. Unconformably overlies Espiritu Santo Formation of Arroyo Penasco; unconformably underlies Log Springs, La Pasada, or Flechado Formations. Includes (ascending): Macho, Turquillo (new name), Manuelitas, and Cowles Members. Age changed from Early Mississippian to: Late Mississippian (Meramecian and Chesterian). (Armstrong and Mamet, 1974.)

Age changed from Carboniferous to: Pennsylvanian. (Richter and Dutro, 1975.)

Geographically restricted from Montana; replaced by Muddy Sandstone-(now raised to formation rank), Skull Creek Shale, basal part of Mowry Shale, or Fall River Sandstone. Thermopolis Shale remains in good usage in Wyoming. (Rice, this report, p. A66.)

Age changed from Pliocene to: Miocene(?) and Pliocene. (Ashley, 1974.)

Geographically extended into south-central Utah subsurface. (Peterson and Barnum, 1973a, b.)

Geographically restricted to Pend Oreille River Valley in northeastern Washington. (Miller, 1974a.)

Tioga Bentonite Bed geographically extended into south-central Pennsylvania; name changed to Tioga Metabentonite Bed, and Tioga reassigned to Needmore Shale. Tioga usage remains unchanged elsewhere. (de Witt, 1974.)

Toledo Formation abandoned; its rocks now assigned to (ascending): Yamhill Formation, Nestucca Formation, and Alsea Formation (new name). (Snavely and others, 1975.)

Age changed from Middle Silurian to Middle or Late Devonian to: Early(?) Silurian to Middle Devonian (Llandoverian? to Givetian?). (Oliver and others, 1975.)

Geographically extended into western Tennessee. (Parks and Russell, 1975.)

Tomera Formation of Dott (1955) adopted. Overlies Moleen Formation; underlies Strathearn Formation. (Smith and Ketner, 1975.)

Toro Formation of Fairbanks (1904) (abandoned by Taliaferro) (1944) and replaced by his Marmolejo Formation) reinstated and adopted as having first priority for usage.

(Hall, 1974.) 


\begin{tabular}{lll}
\hline Name Age Location \\
\hline
\end{tabular}

Trace Creek Shale Member Middle Pennsylvanian (late Arkansas (of Bloyd Formation or Morrowan). Shale).

Tracy Creek Quartz La- Oligocene Southwestern Colorado tite.

Trail Ridge Member (of Miocene or Pliocene South-central Nevada Thirsty Canyon Tuff).

Treasure Mountain Tuff _. late Oligocene Southwestern Colorado --

Tub Spring Member (of In- late Miocene Southern Nevada dian Trail Formation or of Belted Range Tuff).

Tunnel Spring Tuff Turquillo Member (of Late Tererro Formati in) (o Arroyo Penasco Group).

Tuscaloosa Group or For- Late Cretaceous (Gulfian). mation or Loan or Gravel.

Tyringham Gneiss Precambrian

Mississippian

Western Utah

(Meramecian).

North-central New Mexico.

Alabama, Arkansas, Mississippi, Florida, Georgia, North and South Carolina, Tennessee, and Kentucky.

Massachusetts

Union Valley Sandstone_- Early Pennsylvanian (early East-central Oklahoma Morrowan).

Valley Springs Formation_- late Oligocene to middle California Miocene.

Vassalboro Formation _.... Silurian and Devonian _... inaine

Vindicator Rhyolite

Oligocene

South-central Nevada

Vinini Formation

Early, Middle, and Late OrNevada dovician.

Wah Wah Limestone (of Po- Early Ordovician Southwestern Utah gonip Group).

Walden Creek Group (of Precambrian

North Carolina and TenOcoee Series). nessee.

Walloomsac Formation Middle and Late(?) Ordovi- iNew York, Vermont, Massor Slate. cian. achusetts.

Wapanucka Limestone _... Early and Middle Pennsyl- Oklahoma vanian (Morrowan).

Warm Creek Shale Late Cretaceous Montana

Watahomigi Formation (of Early and Middle Pennsyl- Northwestern Arizona Supai Group). vanian (Morrowan and Atokan). 
Revision and reference

Age changed from Early Pennsylvanian to: Middle Pennsylvanian (Morrowan). (Gordon, this report, p. A54.)

Age changed from Oligocene and older(?) to: Oligocene. (Lipman 1975.)

Age changed from Pliocene to: Miocene or Pliocene. (Ashley, 1974.)

Stratigraphically restricted; its unnamed upper tuff unit removed and raised in rank to formation as Masonic Park Tuff (new name). (Lipman, 1975.)

Indian Trail Formation abandoned. Its rocks now included in (ascending): Fraction Tuff, Redrock Valley Tuff, and Crater Flat Tuff (all three now geographically extended). Indian Trail's two members (ascending)-Tub Spring and Grouse Canyon-now geographically restricted to area of reassignment to Belted Range Tuff. (Dixon and others, this report, p. A49.)

Tunnel Spring Tuff of Bushman (1973) adopted. (Hintz, 1974c.)

Turquillo Member adopted as one of four members of Tererro Formation (of Arroyo Penasco Group). Disconformably overlies Espiritu Santo Formation or Macho Member of Tererro; conformably underlies Manuelitas Member of Tererro. (Armstrong and Mamet, 1974.)

Geographically restricted from North and South Carolina; its rocks now assigned to Cape Fear Formation (now reinstated for usage in North and South Carolina). Tuscaloosa usage remains good elsewhere. (Sohl, this report, p. A68.)

Tyringham Gneiss reinstated as meta-intrusive orthogeneiss, replacing in part former rocks of Becket Granite Gneiss (now abandoned). (Ratcliffe, 1974b.)

Union Valley Sandstone Member of Hollingsworth (1934) adopted as Union Valley Sandstone (rank raised) as used by Ham and others (1969). Overlies unnamed shale interval which overlies Rhoda Creek Formation; underlies Wapanucka Limestone. (Gordon, this report, p. A54.)

Age changed from Miocene to: late Oligocene to Middle Miocene. (Duffield and Sharp, 1975.)

Age changed from Silurian or Devonian to: Silurian and Devonian. (Stewart and Wones, 1974.)

Age changed from Oligocene or Miocene to: Oligocene. (Ashley, 1974.)

Age changed from Early and Middle Ordovician to: Early, Middle, and Late Ordovician. (Smith and Ketner, 1975.)

Wahwah Limestone of Hintze (1951) adopted as Wah Wah Limestone and assigned to Pogonip Group. Conformably overlies Fillmore Formation and conformably underlies Juab Limestone, both of Pogonip Group. (Hintze, 1974c.)

Geographically extended into northern Georgia. Changed from subdivision of Ocoee Series to subdivision of Ocoee Supergroup. (Higgins and Zietz, 1975.)

Age changed from Middle Ordovician to Middle and Late(?) Ordovician. (Ratcliffe, 1974a.)

Age changed from Pennsylvanian to: Early and Middle Pennsylvanian (Morrowan). (Gordon, this report, p. A54.)

Warm Creek Shale abandoned; its rocks replaced by (ascending): Belle Fourche Shale, Greenhorn Formation, Carlile Shale, Niobrara Formation, and Telegraph Creek Formation. (Rice, this report, p. A66.)

Watahomigi Formation adopted as lowermost of four formations of Supai Group. Unconformably overlies Redwall Limestone; conformably underlies Manakacha Formation (new name) of Supai Group. (McKee, 1975.) 


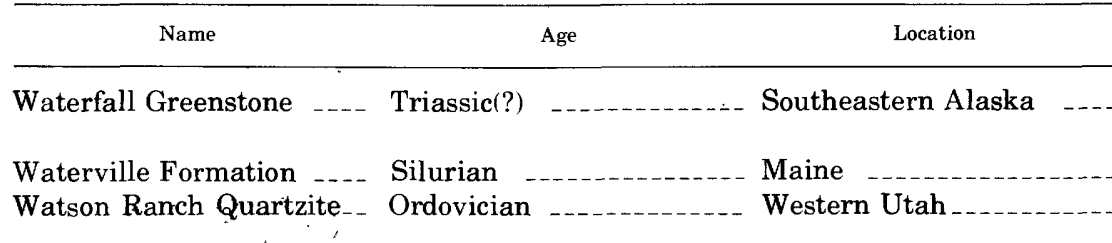

Wescogame Formation (of Late Pennsylvanian (Vir- Northwestern Arizona Supai Group). . . gilian).

Wesley Shale (of Jackfork Early Pennsylvanian (early Southeastern Oklahoma -Group). . . Morrowan).

West Elk Breccia ......... Oligocene Southwestern Colorado

West Foreland Formation.- Tertiary Southearn Alaska

West Fork Formation (of Precambrian Y East-central Idaho Lemhi Group).

Wheeler Formation Middle Cambrian

Utah

Whirlwind Formation Middle Cambrian Western Utah

White River Ash. Bed (of Holocene East-central Alaska Engineer Loess).

Whitestripe Marble Triassic(?)

Southeastern Alaska

Whitmore Wash Member Early Mississippian Arizona (of Redwall Limestone).

Wilber Ash Bed (of Engi- Holocene East-central Alaska neer Loess).

Wilbert Formation

Precambrian Z

East-central Idaho

Wildhorse Mountain For- Late Mississippian and Southeastern Oklahoma -mation. Early Pennsylvanian (latest Chesterian and Morrowan).

Wills Creek Shale (of Cay- Late Silurian Maryland, Virginia, West uga Group). Virginia, and Pennsylvania.

Winchester Limestone._._. Middle and Late Ordovi- Kentucky cian.

Wingate. Hill Drift or Gla- late Pleistocene ciation.

Washington

Wolf Mountain Creek For- Precambrian X mation (of Emperor Volcanic Complex́):

Northern Peninsula, Michigan. 
Assigned to Kelp Bay Group. Overlies Pinnacle Peak Phyllite; underlies Khaz Formation (new name). (Loney and others, 1975.)

Age changed from Silurian(?) to: Silurian. (Stewart and Wones, 1974.)

Watson Ranch Tongue of Swan Peak Quartzite of Webb (1956) adopted as Watson Ranch Quartzite as used by Hintze (1973). Overlies Pogonip Group (Lehman Formation); underlies Crystal Peak Dolomite. (Hintze, 1974a.)

Wescogame Formation adopted as one of four formations of Supai Group. Unconformably overlies Manakacha Formation (new name) and unconformably underlies Esplanade Sandstone (now raised from member rank) (both of Supai Group). (McKee, 1975.)

Wesley Formation of Harlton (1938) adopted as Wesley Shale, one of five named formations of Jackfork Group. Overlies Markham Mill Formation and underlies Game Refuge Sandstone, both of Jackfork. (Gordon, this report, p. A54.)

Age changed from Oligocene and older(?) to: Oligocene. (Lipman, 1975.)

West Foreland Formation of Calderwood and Fackler (1972) adopted. Underlies Hemlock Conglomerate. (Adkison, 1975.)

West Fork Formation adopted as one of five formations assigned to Lemhi Group. Overlies Inyo Creek Formation and underlies Big Creek Formation (both new names and both assigned to Lemhi). (Ruppel, 1975.)

Name changed from Wheeler Formation to Wheeler Shale in type area (western Juab and western Millard Counties, western Utah); name remains unchanged elsewhere. (Hintze, 1974d.)

Whirlwind Formation of Robison (1960) adopted. Overlies Dome Limestone; underlies Swasey Limestone. (Hintze, 1974e.)

White River Ash Bed of Lerbekmo and others (1968) adopted as bed within Engineer Loess (newly named) in east-central Alaska and adjoining Yukon Territory of Canada. (Péwé, 1975a.)

Assigned to Kelp Bay Group. Overlies Goon Dip Greenstone; underlies Pinnacle Peak Phyllite. (Loney and others, 1975.)

Geographically extended into south-central Utah subsurface. (Peterson and Barnum, 1973a, b.)

Wilber Ash Bed adopted as bed within Engineer Loess (newly named) in Fairbanks area and northward to Livengood. (Péwé, 1975a.)

Wilbert Formation adopted. Faulted at base; underlies Summerhouse Formation (new name). (Ruppel and others, 1975.)

Wildhorse Mountain Formation of Harlton (1938) adopted as lowermost of five named formations of Jackfork Group. Overlies Chickasaw Creek Shale of Stanley Group; underlies Prairie Mountain Formation of Jackfork. (Gordon, this report, p. A54.)

In south-central Pennsylvania, name changed to Wills Creek Formation; name remains Wills Creek Shale elsewhere. (de Witt, 1974.)

Winchester Limestone abandoned; its rocks now included in interval extending from top of Brannon Member of Lexington Limestone to base of Garrard Siltstone (=Tanglewood Limestone, Strodes Creek, and Millersburg Members of Lexington Limestone and Clays Ferry Formation). (Black, 1974.)

Wingate Hill Drift assigned to Salmon Springs(?) Glaciation and no longer considered to be a glaciation unit. (Crandell and Miller, 1974.)

Wolf Mountain Creek Formation adopted as formation in upper part of Emperor Volcanic Complex (new name), with Brotherton sill as its feeder. Overlies and intertongues with Ironwood Iron-formation and other rocks in Emperor Volcanic Complex; underlies Copps Formation. (Trent, this report, p. A69.) 


\begin{tabular}{|c|c|c|}
\hline Name & Age & Location \\
\hline Woodchopper Volcanics & $\begin{array}{l}\text { Early(?) and Middle Devon- } \\
\text { ian (Emsian? to Give- } \\
\text { tian?). }\end{array}$ & Northeastern Alaska \\
\hline $\begin{array}{l}\text { Woodhurst Limestone } \\
\text { Member (of Lodgepole } \\
\text { Limestone) (of Madison } \\
\text { Group). }\end{array}$ & $\begin{array}{l}\text { Early Mississippian (Osa- } \\
\text { gean). }\end{array}$ & $\begin{array}{l}\text { Montana, Wyoming, and } \\
\text { Idaho. }\end{array}$ \\
\hline
\end{tabular}

Yellowjacket Formation _- Precambrian Y East-central Idaho

\title{
RESTORATION OF THE NAME COVE CREEK LIMESTONE FOR THE AREA OF THE GREENDALE SYNCLINE IN SOUTHWEST VIRGINIA
}

\author{
By Wallace de WitT, JR.
}

Because of a misinterpretation of the stratigraphic nomenclature used by Wilpolt and Marden (1949) in their study of the Mississippian rocks along the Allegheny Front in southwest Virginia, the U.S. Geological Survey inadvertently abandoned the usage of the names Little Valley Limestone, Fido Sandstone, and Cove Creek Limestone. Wilpolt and Marden's work in southwest Virginia did not include the Greendale syncline, which contains the type localities of the Little Valley, Fido, and Cove Creek. Since the abandonment of these three units, the Little Valley Limestone and the Fido Sandstone have been returned to good standing as valid stratigraphic units in the Greendale syncline. The purpose of this note is to document the existence of the Cove Creek Limestone as a mappable stratigraphic entity and to have its name restored to good standing in the lexicon of stratigraphic nomenclature.

The Greendale syncline (fig. 1) is a large structure about 150 miles $(240 \mathrm{~km})$ long and as much as 16 miles $(25.6 \mathrm{~km})$ wide in parts of Bland, Smyth, Washington, and Scott Counties, Va., and in parts of Sullivan, Hawkins, and Grainger Counties, Tenn. The syncline is bound on the north by the Copper Creek thrust and on the south by the Saltville thrust, which brings a sequence of Cambrian through Silurian rocks locally against Upper Mississippian rocks at the surface along the south flank of the syncline. The Cove Creek Limestone (Upper Mississippian, Chesterian) is present at the surface from a locality north of Lindell, Washington County, Va. (Butts, 1940), southwest for 53 miles $(84.6 \mathrm{~km})$ to the Virginia-Tennessee border, 
Revision and reference

Age changed from Middle Devonian to: Early(?) and Middle Devonian (Emsian? to Givetian?). (Oliver and others, 1975.$)$

Name changed from Woodhurst Limestone Member to Woodhurst Member. (Sando and Dutro, 1974.1

Geographically extended into Oregon Coast Range, northwestern Oregon, replacing lower part of Toledo Formation (lower part of its Moody Shale Member) (both names now abandoned). Underlies Nestucca Formation, which underlies Alsea Formation (new name), replacing middle and upper parts of Toledo Formation, respectively. (Snavely and others, 1975.)

Yellowjacket Formation no longer assigned to Belt Supergroup. Age changed from Precambrian to: Precambrian Y. (Ruppel, 1975.)

and although it is not recognized as a discrete unit in the Mississippian sequence in Tennessee, the Cove Creek is undoubtedly present a considerable distance to the southwest in Tennessee.

In 1927, Butts introduced the name Cove Creek Limestone for about 1,000 feet $(304.8 \mathrm{~m})$ of commonly argillaceous yellowishweathering medium- to dark-gray calcarenite and calcilutite which overlies his Fido Sandstone and underlies the Pennington Shale in the Greendale syncline in Scott and Washington Counties, Va. Butts' (1933) map of the Appalachian Valley in Virginia shows the extent of the Cove Creek Limestone in southwest Virginia, In 1940, Butts (p. 382) correlated the Cove Creek Limestone of the Greendale syncline with his Glen Dean Limestone at Cumberland Gap and with the Bluefield Shale of southwest West Virginia. He noted (Butts, 1940, p. 382 ) that "These three names designate three different facies of what is believed to be the same stratigraphic unit in different areas."

In 1941, Paul Averitt mapped a segment of the Greendale syncline in the vicinity of the Early Grove gas field of Scott County in great detail at the scale of 1:24,000 and used the Cove Creek Limestone as one of his principal mapping units. He (Averitt, 1941, p. 9-11) gave more detailed stratigraphic data on the Cove Creek Limestone, including mention of several beds of coarse-grained reddish-weathering sandstone in the upper part of the limestone. Locally near Early Grove, the Cove Creek Limestone is more than 1,100 feet $(335.3 \mathrm{~m})$ thick. The base of the formation is clearly marked by an abrupt change from red coarse-grained sandstone of the underlying Fido Sandstone to thick-bedded slightly argillaceous limestone in the basal part of the Cove Creek. The upper boundary of the Cove Creek is commonly concealed because both the upper part of the Cove Creek and the overlying Pennington Shale are relatively nonresistent and exposures of this part of the sequence are sparse. Locally, however, 


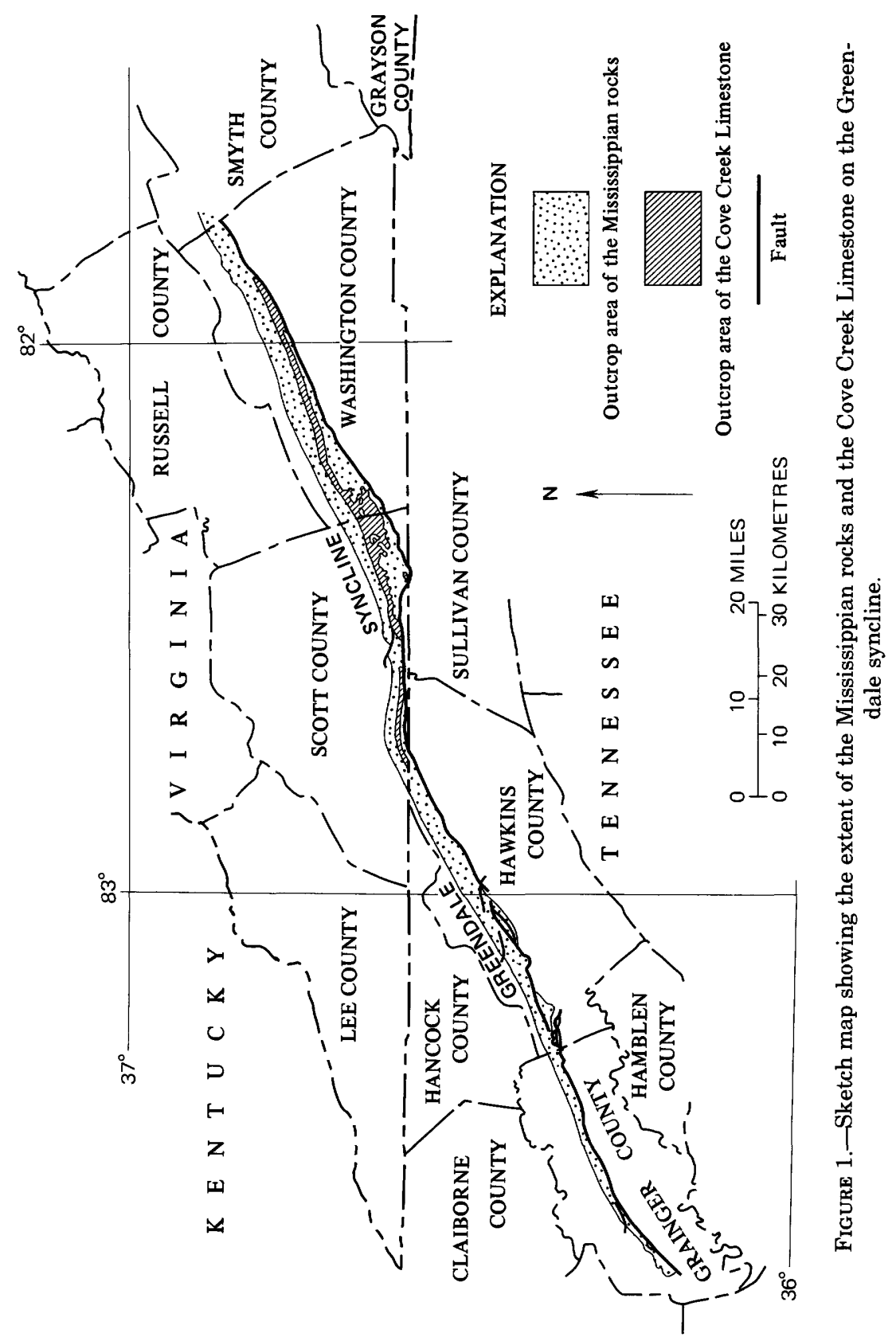


the uppermost massively bedded slightly siliceous limestone of the Cove Creek may be seen underlying the basal calcareous shale of the Pennington (Averitt, 1941, p. 13).

Wilpolt and Marden (1949, 1959) studied the middle and Upper Mississippian rocks along the Allegheny Front from Bluefield, W. Va., southwest to Cumberland Gap, Ky.-Tenn.-Va., and in the subsurface to the west of the Allegheny Front in Kentucky, Virginia, and West Virginia. Their work did not include the Greendale syncline. They recognized that their Bluefield Formation, formerly the Bluefield Shale, was roughly equivalent to the Cove Creek Limestone as suggested by Butts (1940, p. 382). They dropped the designation "shale" from the Bluefield "because of the heterogeneous character of the rocks" (Wilpolt and Marden, 1959, p. 596). Although the Bluefield along the Allegheny Front is composed largely of shale, it also contains some argillaceous limestone, siltstone, sandstone, and locally thin beds of impure coal or coaly shale. The shale ranges in color from grayish black to reddish brown. The lithology of the Bluefield Formation is considerably different from the lithology of the Cove Creek Limestone. Further, the exact stratigraphic relationship of the two formations cannot be determined because the units are in different fault slices, and the Fido Sandstone, which marks the base of the Cove Creek Limestone in the Greendale syncline, and the Stoney Gap Sandstone Member, which is the basalt unit of the Pennington along the Allegheny Front, have not been identified on opposite sides of the Copper Creek thrust-fault belt, which separates the Greendale syncline from the Allegheny Front.

The Cove Creek Limestone is a lithologically distinctive, mappable stratigraphic unit along 53 miles $(84.8 \mathrm{~km})$ of the Greendale syncline in Scott and Washington Counties, Va. It is more than 1,000 feet $(304.8 \mathrm{~m})$ thick and is lithologically unlike the underlying or overlying formations. The Cove Creek Limestone is also lithologically distinct from its near stratigraphic equivalent, the Bluefield Formation of the Allegheny Front. The name Cove Creek Limestone was abandoned by error, not by intent. These data show that the Cove Creek Limestone is a valid mappable stratigraphic unit, and it is herein reinstated in good standing in the Lexicon of Geologic Names.

\section{ABANDONMENT OF THE INDIAN TRAIL FORMATION AND DISTRIBUTION OF CERTAIN EQUIVALENT ASH-FLOW TUFFS, EASTERN NEVADA TEST SITE}

By G. L. Dixon, K. A. Sargent, and W. J. Carr

The Indian Trail Formation of Tertiary age, at Nevada Test Site and vicinity, Nevada, is herein abandoned. 
The Indian Trail Formation was defined by Poole and McKeown (1962) to include the lowest three members of the former Oak Spring Formation as used by Hinrichs and Orkild (1961). These members are, in ascending order: lower member, Tub Spring, and Grouse Canyon. The lower member consists predominantly of rhyolitic to quartz latitic ash-flow tuff, ash-fall tuff, and reworked tuff. The Tub Spring and Grouse Canyon Members are compound cooling units of comenditic ash-flow tuff. Sargent, Noble, and Ekren (1965) restricted the name Indian Trail Formation to the eastern part of the Nevada Test Site (NTS) and placed the Tub Spring and Grouse Canyon Members in the Belted Range Tuff. Belted Range Tuff should now be used throughout NTS and vicinity.

Mappers since 1965 (Ekren and others, 1971; Sargent and Orkild, 1973; Byers and others, 1976; W. J. Carr, written commun., 1970) have found that as many as seven ash-flow tuffs could be separated from the lower member of the Indian Trail Formation and traced into other parts of NTS. The abandonment of Indian Trail Formation allows the proper recognition of these ash-flow tuff units throughout their extent at NTS and vicinity. Three of these tuffs, Fraction Tuff, Redrock Valley Tuff, and Crater Flat Tuff, are widespread and stratigraphically important for correlation purposes. Their identification is helpful in the subsurface interpretation of Yucca Flat (figs. 2-4).

Crater Flat Tuff (fig. 2) is a nonwelded to partially welded ash-flow tuff of Miocene age (13-14 m.y.; Marvin and others, 1970) and is believed to have a source area west of the NTS in the Timber Mountain-Oasis Valley caldera complex (Byers and others, 1976). In southern Plutonium Valley, southeast of Yucca Flat (fig. 2), the unit attains a maximum thickness of $152 \mathrm{~m}$ in outcrop. In the subsurface, the Crater Flat Tuff is $63 \mathrm{~m}$ thick in central Yucca Flat and $50 \mathrm{~m}$ thick below Rainier Mesa (S. S. Terry and D. R. Miller, written commun., 1975).

Redrock Valley Tuff (fig. 3) is a nonwelded to densely welded ashflow tuff of Miocene age (15-16 m.y.) and, like the Crater Flat Tuff, has a probable source area in the Timber Mountain-Oasis Valley caldera complex. At the type section (fig. 3), Redrock Valley Tuff attains a maximum thickness of $136 \mathrm{~m}$. In the subsurface, the unit is $300+\mathrm{m}$ thick in drill hole TW-8 (Orkild and Jenkins, 1970) southwest of Rainier Mesa.

Fraction Tuff (fig. 4) is a compound cooling unit of Miocene age (16-18 m.y.) composed of as many as three separate ash flows. The probable source area of the Fraction Tuff is north of the NTS in the Nellis Air Force Base Bombing and Gunnery Range near Trailer Pass (Ekren and others, 1971). In the eastern part of NTS, the unit(s) 


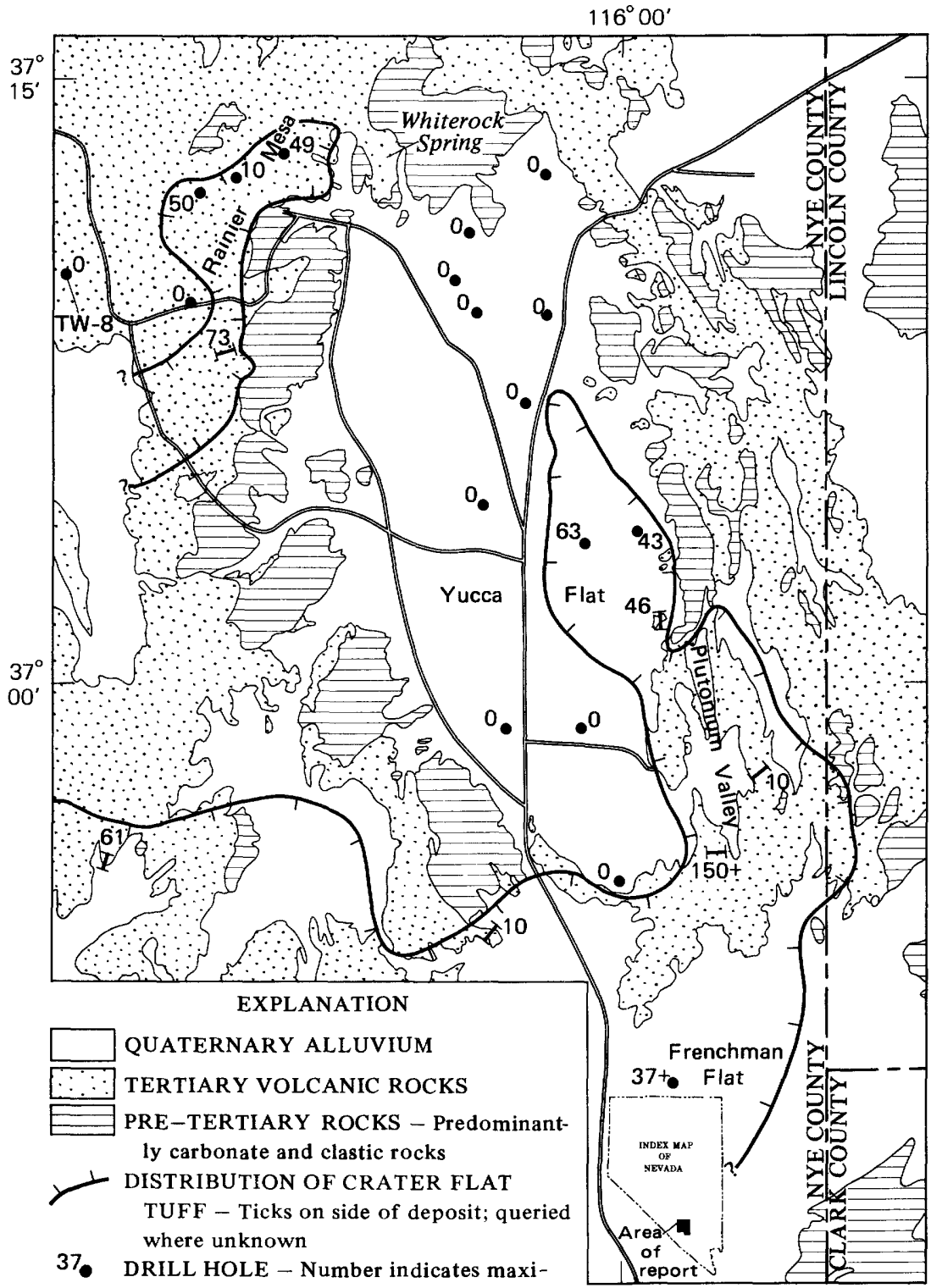

mum thickness of the tuff unit in metres

61. OUTCROP - Number indicates maximum

thickness of the tuff unit in metres

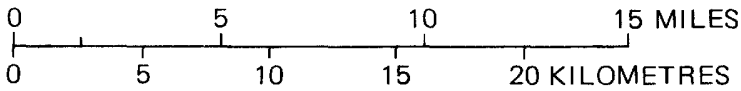

FIGURE 2.-Map showing known distribution of the Crater Flat Tuff in the eastern part of the Nevada Test Site, Nye County, Nev. 


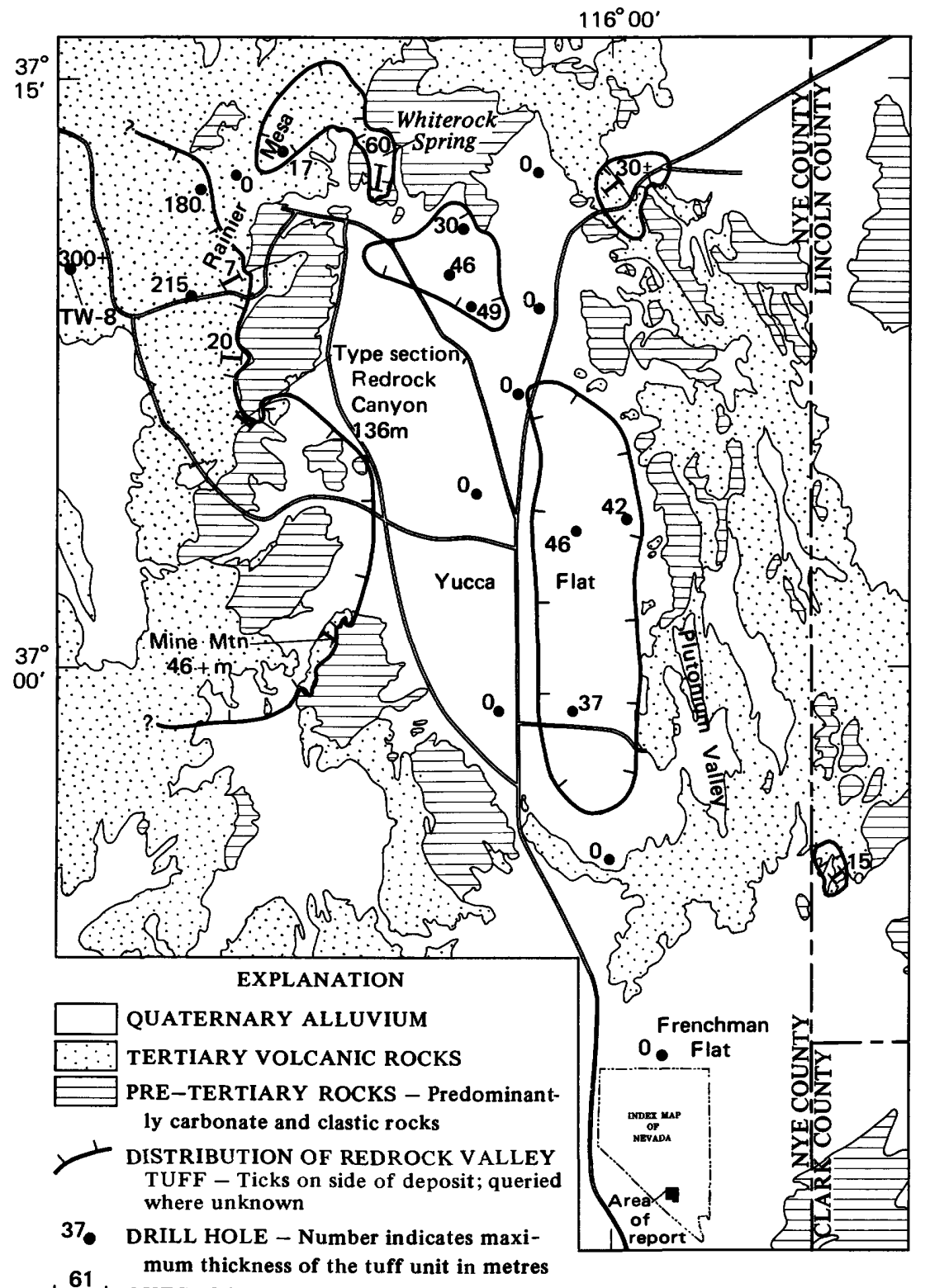

61 mum thickness of the tuff unit in metres

thickness of the tuff unit in metres

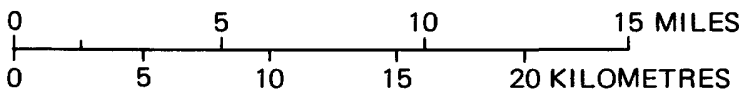

FIGURE 3.-Map showing known distribution of the Redrock Valley Tuff in the eastern part of the Nevada Test Site, Nye County, Nev. 


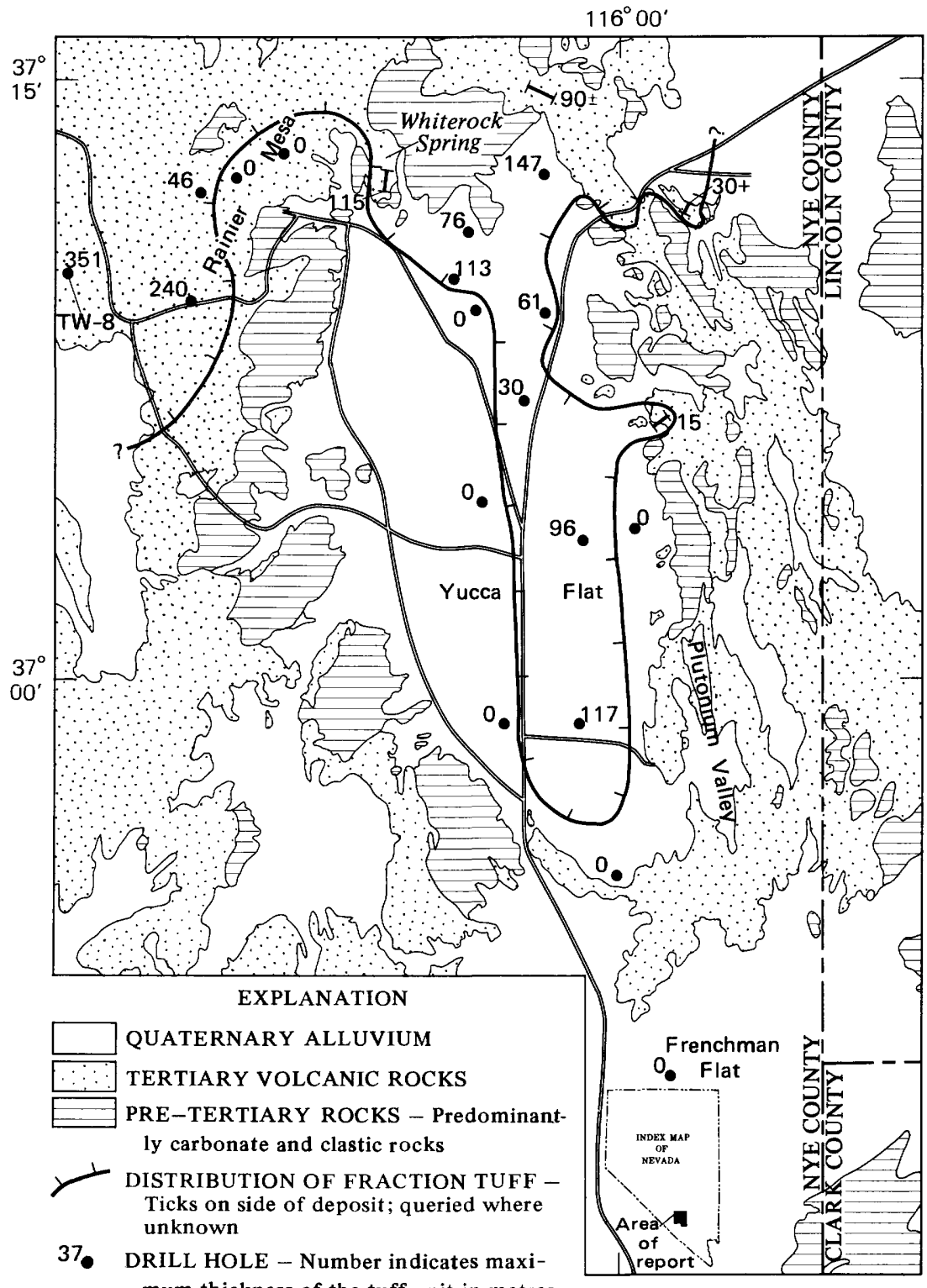

61 mum thickness of the tuff unit in metres

OUTCROP - Number indicates maximum thickness of the tuff unit in metres

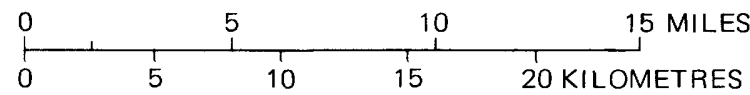

FIGURE 4.-Map showing known distribution of the Fraction Tuff in the eastern part of the Nevada Test Site, Nye County, Nev. 
attains a maximum thickness of $115 \mathrm{~m}$ near Whiterock Spring (fig. 4). In the subsurface, the Fraction Tuff is $351 \mathrm{~m}$ thick in drill hole TW-8 (Orkild and Jenkins, 1970) southwest of Rainier Mesa (fig. 4).

Several other ash-flow tuffs, which include the tuff of Whiterock Spring, tuff of White Blotch Springs, Shingle Pass Tuff, and Monotony Tuff, were separated by Sargent and Orkild (1973) from the lower member. Those units are not discussed here, as their distribution in the Yucca Flat is limited or little known.

\section{CORRELATION CHART OF CARBONIFEROUS ROCKS IN ARKANSAS AND OKLAHOMA}

\section{By Mackenzie Gordon, JR.}

A correlation chart prepared by the writer for inclusion in a paper written with C. G. Stone (Gordon and Stone, 1976) of the Arkansas Geological Commission contains some geologic names in general use but not previously adopted by the U.S. Geological Survey. This provides a splendid opportunity for the U.S. Geological Survey to adopt some of the formational names previously used by the Oklahoma Geological Survey and to revise a few Arkansas names. Altogether, 43 names of formations are affected.

The changes are all contained on the correlation chart (fig. 5). The changes for those formations having an asterisk are in the listing of nomenclatural changes at the beginning of this report.

\section{COOPER MARL IN THE COASTAL PLAIN OF SOUTH CAROLINA AND GEORGIA}

\section{By Joseph E. Hazel}

The term Cooper was originally used for beds along the Cooper River (Tuomey, 1848). Subsequently, the Ashley beds of Tuomey (for beds on both the Ashley and Cooper Rivers) have been included in the Cooper (Cooke, 1936). Cooke (1936) assigned the Cooper to the upper Eocene; however, Cooke and MacNeil (1952) considered the Cooper to be of early Oligocene age (also see Pooser, 1965, and references therein).

Recent work on the Cooper by members of the U.S. Geological Survey reveals that beds assigned to the Cooper contain fossils of late Eocene, Oligocene, and perhaps even very early Miocene age. However, this definitely does not mean that the Cooper represents continuous deposition through this interval of time; at least two contacts within what is called Cooper probably represent unconformities of at least local significance. Thus, the lithologically similar beds assigned to the Cooper may represent at least two depositional cycles. 
It will take more effort in the area to determine what the Cooper really represents in terms of geologic history and what lithostratigraphic nomenclature is best to reveal this history. For the time being, we recommend carrying the Cooper as a formation of late Eocene, Oligocene, and possibly early Miocene age.

\title{
PALEOBIOGEOGRAPHY OF JURASSIC DEPOSITS IN THE CONTERMINOUS UNITED STATES
}

\author{
By RALPH W. IMLAY
}

During Jurassic ${ }^{1}$ time, marine sediments of considerable thickness, including bedded salt, were probably deposited on the outer part of the Atlantic Continental Shelf of the United States. The inner part of the shelf may also have been inundated during Oxfordian to Tithonian time, coincident with extensive flooding elsewhere in the Atlantic Ocean and in the Gulf of Mexico.

During the Early Jurassic neither marine nor continental sediments may have been deposited within the area now covered by the Gulf of Mexico. Nonetheless, a marine embayment of Sinemurian to possibly early Pliensbachian Age did extend northward from the Pacific Ocean to east-central Mexico, where it terminated against a mass of metamorphic and granitic rocks in eastern Veracruz. The marine sediments deposited are carbonaceous, contain much plant material and some coal, and evidently were laid down in a warm humid climate. During the later Early Jurassic, they were strongly folded, faulted, intruded by igneous rocks, slightly metamorphosed, and then eroded. Presumably erosion took place mostly in Toarcian time after tectonic movements in Pliensbachian time.

During the Middle Jurassic, marine sediments apparently were not deposited within the gulf region until the late Bathonian. Continental sedimentation, however, took place in both Mexico and Cuba. In

\footnotetext{
${ }^{1}$ The boundary between the Middle and Upper Jurassic has previously been considered by the U.S. Geological Survey to be between the top of the European Bathonian Stage and the bottom of the Callovian Stage. However, the boundary is now changed herein to between the top of the Callovian and the bottom of the Oxfordian as the more universally accepted usage. The present generally recognized European stages for the Jurassic are:

Џpper Jurassic

Tithonian

Kimmerıdgian

Oxfordian

Middle Jurassic

Callovian

Bathonian

Bajocian

Lower Jurassic

Toarcian

Pliensbachıan

Sinemurian

Hettangian
} 


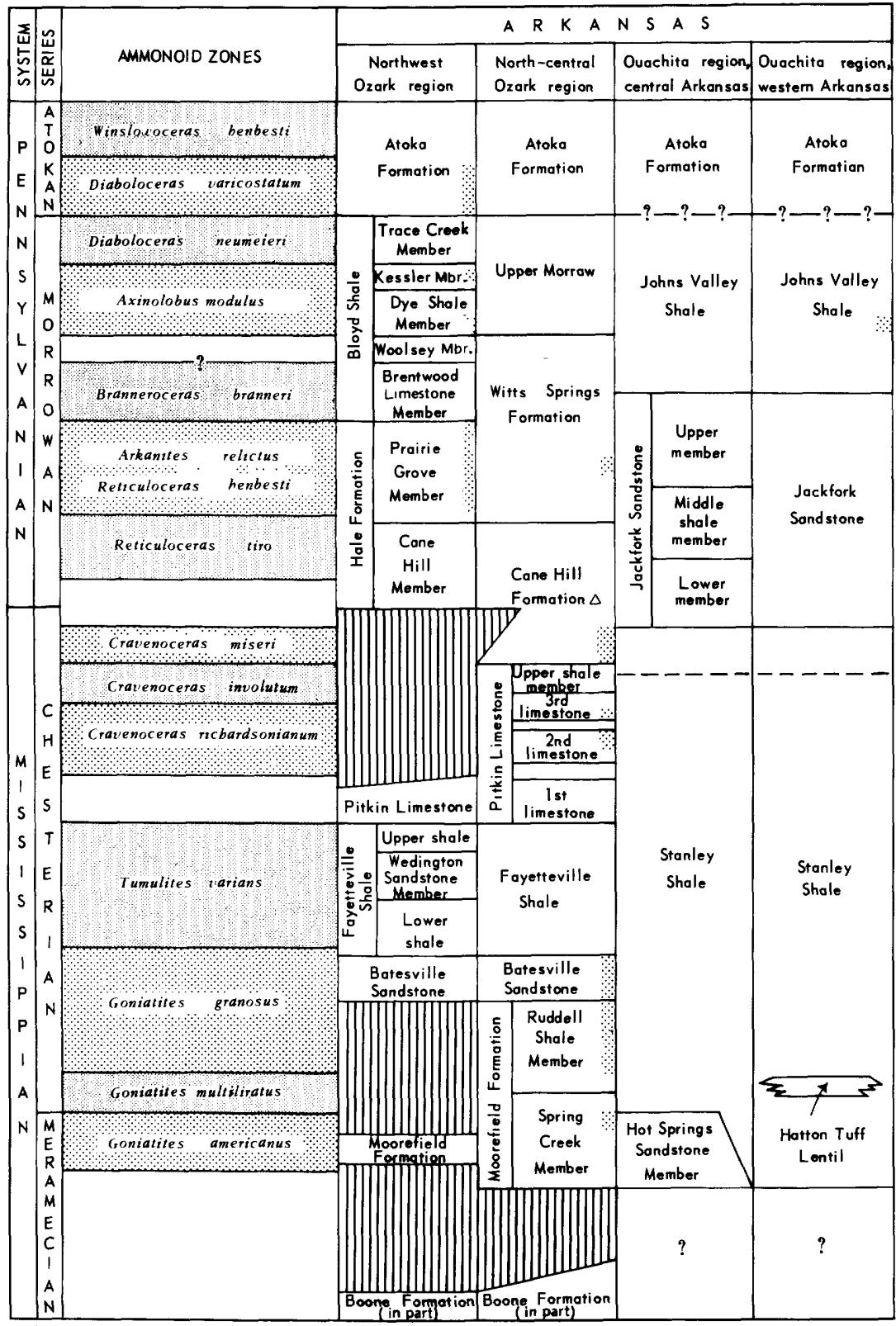

$\Delta$ Includes latest Mississippian age "Peyton Creek beds" of McCaleb and others (1964).

FigURE 5.-Correlation chart of Carboniferous rocks in Arkansas and Oklahoma. 


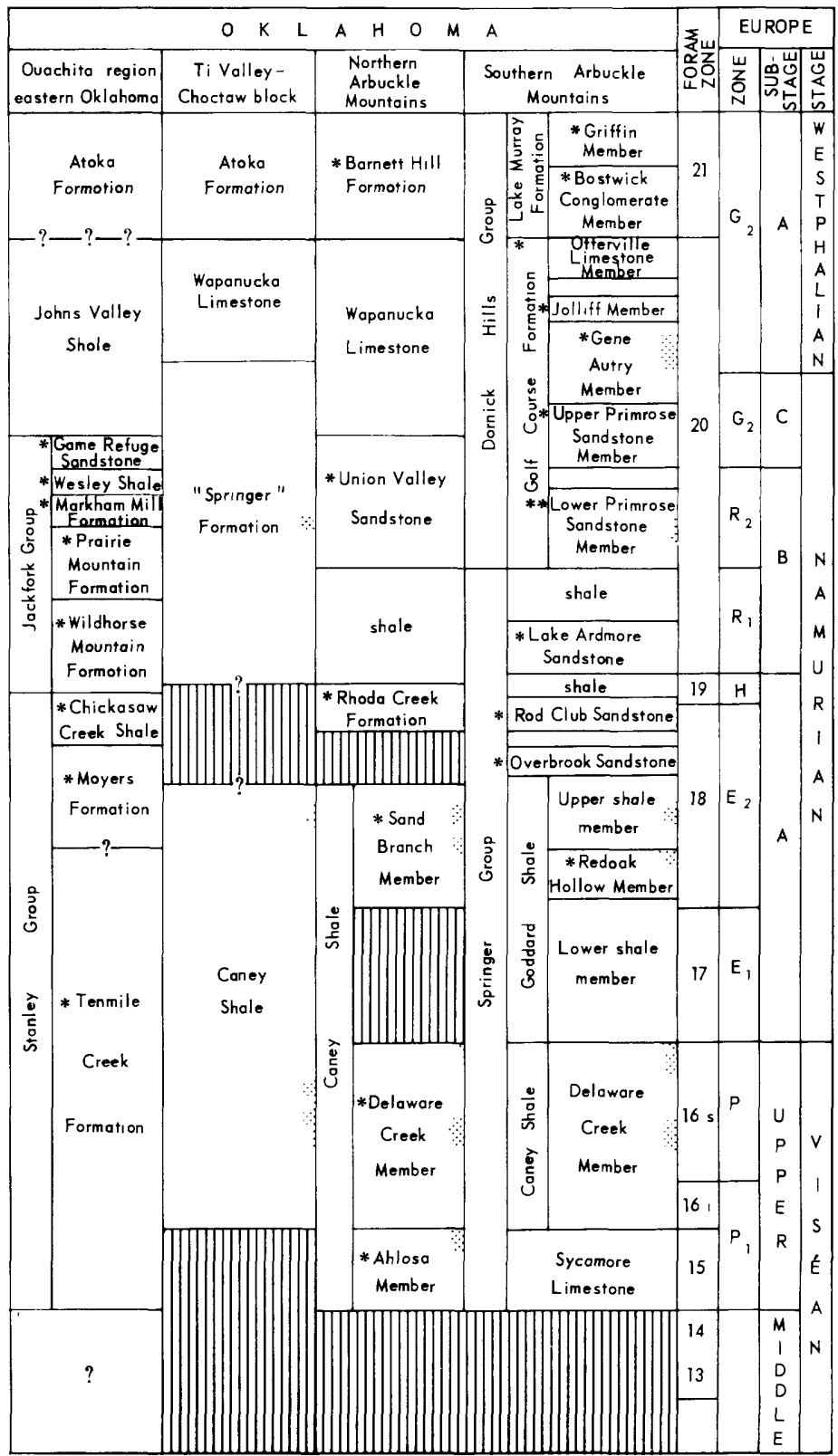

* The changes for those formations having an asterisk are discussed in the listing of nomenclatural changes.

Figure 5.-Continued. 
east-central Mexico, plant fossils indicate that continental deposition began in the early Bajocian over a larger area than that covered by the marine Lower Jurassic beds. Deposition continued until sometime in the Bathonian, and the deposits were somewhat eroded before early Callovian. In Cuba, thousands of feet of carbonaceous, plantbearing beds were deposited during the Bajocian and Bathonian and possibly a little earlier. These plant-bearing beds show that the climate was warm and humid throughout the gulf region during most of the Middle Jurassic.

During Callovian to early middle Oxfordian time, the gulf region deepened and received some marine waters from the major oceans, resulting in the deposition of thick masses of salt at various places. One marine embayment apparently extended westward into Cuba and was probably the major source of the salt. Another embayment extended from the Pacific Ocean into the Huasteca area of eastcentral Mexico, where it was separated from the gulf at least in part by a land barrier near the present gulf coast. Salt was deposited mainly during late Callovian to early middle Oxfordian time, but deposition may have started in middle Callovian time. Salt deposition was apparently accompanied in nearby areas in east-central and northeastern Mexico by deposition of varicolored continental beds and some red-weathering lava. The climate during this time was probably hot and dry in the gulf region. The red silt and sand were probably derived from upland areas west or north of the gulf where the climate was hot and seasonally rainy.

Near the middle of the Oxfordian, major portals to the oceans were opened abruptly by major structural movements, and, as a result, sea water of normal salinity flowed quickly across the saline deposits and far beyond. Subsequently, during the later Jurassic, the Gulf of Mexico gradually deepened and widened. Landmasses arose north of the gulf basin and shed considerable sediment southward, and deposition prevailed in open marine water from Cuba and Florida westward to central Mexico. Deposition continued into the Cretaceous in most parts of the gulf region except in some northern nearshore areas. The climate in the gulf region during Oxfordian to Tithonian time was probably hot and moderately humid. Rainfall apparently became greater after the early Kimmeridgian and was greater in eastern Mexico than in the southeastern United States, as shown by the presence of coal beds in Mexico. On the whole, the climate was probably similar to that in the western interior region during deposition of the Morrison Formation.

In the Pacific Coast during Jurassic time, marine sediments were deposited at depths ranging from very shallow to very deep. Tre- 
mendous thicknesses of sediment were involved, much volcanic material was included, and the sites of deposition gradually shifted westward.

During the Early Jurassic, a sea extended from the Pacific coast as far east as the Snake River in easternmost Oregon and a similar distance east in Nevada. The deepest part of the sea probably trended northward through westernmost Nevada into eastern Oregon and beyond, as indicated by continuous deposition of fine-grained sediments from the Triassic into the Jurassic. By contrast, in eastern California, Jurassic sedimentation apparently did not begin before the Sinemurian.

During the Bajocian, a shallow sea covered nearly the same area as that earlier in the Jurassic, except for an eastward extension into the western interior region. This sea received a great variety of sediments, which included much volcanic material, except in Nevada. Deposition of beds of Bathonian Age in the Pacific Coast region of the conterminous United States has been demonstrated by fossils only in eastern Oregon. The absence of Bathonian fossils elsewhere could be explained by collecting failure. It could also reflect the beginning of intense volcanism which lasted into the early Oxfordian and which may at first have produced conditions on the sea bottom that were unfavorable for the preservation of fossils.

During the Callovian, marine waters covered most of the present area of California, Oregon, and Washington, and during earliest Callovian, they also extended eastward into the western interior region. Coarse to fine volcanic debris in enormous amounts was ejected from volcanoes and fissures into the sea where it became mixed with sediments derived from islands and larger landmasses. Apparently deposition continued throughout the epoch except in eastern Oregon. The formation of oceanic crust during the Bathonian or Callovian epochs, or both, is suggested by the characteristics of the Rogue Formation in western Oregon.

Marine sedimentation persisted in the Pacific Coast region without any apparent interruption from Callovian to early Kimmeridgian time over a large area, including California, western Oregon, and probably northwestern Washington. During the early Oxfordian, deposition of highly volcanic sediments continued, just as it did during the Callovian. By contrast, from late Oxfordian to early Kimmeridgian, the most common sediments deposited were dark clay and silt that in most places included only fine volcanic material.

At the end of the early Kimmeridgian, marine deposition ceased in areas underlain by the Mariposa Formation in eastern California and by the Galice Formation in western Oregon and in nearby California. 
These areas were then uplifted, and the rocks were folded, intruded locally by igneous rocks, and strongly eroded before the end of the Jurassic.

Elsewhere near the present Pacific Coast, marine sediments were deposited in a few places from the late Kimmeridgian to the Tithonian, but in many other places apparently only during the Tithonian. Some of the sediments, now represented by the Knoxville and Riddle Formations, consist mostly of nonvolcanic terrigenous clastic materials that locally contain limestone lenses and were deposited in shallow waters. Other sediments, represented by the Dothan and Otter Point Formations and by the Franciscan assemblage consist of volcanic clastic materials, breccias, lavas, and chert and were deposited in deep waters. All available evidence indicates that the volcanic sediments were deposited far west of the nonvolcanic sediments and in much deeper waters, but that deposition of both began at about the same time on oceanic crust of late Oxfordian to early Kimmeridgian Age. Evidently oceanic crust was formed at the same time as the Galice and Mariposa Formations were being deposited in areas far to the east.

The climate in California and Oregon during Jurassic time was probably warm, as indicated by the presence of ammonites of Mediterranean (Tethyan) affinities in those States and by the lack of certain ammonites that are common in the Arctic region and along the Pacific Coast as far south as British Columbia. The change is similar to that found in Jurassic ammonite faunules between northwest Europe and the Mediterranean region.

During the Early Jurassic, deposits in the western interior region were being eroded. During the late Oxfordian, Kimmeridgian, and probably early Tithonian, the region received some hundreds of feet of continental beds deposited under fluviatile, lacustrine, and swampy environments. In between, it was invaded five times by marine waters that entered from the west through Idaho, Washington, or Alberta. Three of the invasions were followed by complete withdrawals of the sea from the region, and two, by partial withdrawals.

During the first invasion, the sea entered southeast Idaho early in the Bajocian, extended from there northeast into the Williston basin and southward into southwest Utah, and then withdrew completely near the beginning of the middle Bajocian. In that sea were deposited gypsum, red silt, limy mud, some chert, and, locally in the Williston basin, some salt. The characteristics of these sediments show that the sea was very shallow; that its initial sediments were laid down in highly saline waters and its later sediments in slightly deeper waters that supported some marine organisms; and that it deepened a little in southeastern Idaho. 
The second and greatest marine invasion of the western interior region started in the late middle Bajocian and lasted until the early Callovian. The sea became much shallower in the middle Bathonian and then withdrew nearly completely in late early to middle Callovian. It entered across northern Utah, eastern Idaho, and southern Alberta, surrounded a large island in central Montana, and was much more extensive than the sea of the earlier Bajocian except in eastern and southern Wyoming during late Bajocian to early Bathonian. From late Bathonian to early Callovian, however, it advanced across Wyoming into South Dakota beyond the erosional eastern limit of beds of early Bajocian Age. In this sea were deposited clayey to dense to oolitic lime mud, limy clay and silt, gray to yellow limy sand, and some red silt and gypsum. The sediments deposited at any one time were similar over great distances except for the initial deposits that filled irregularities on the underlying erosion surface. Most of the sediments were deposited as the sea transgressed. Regressive deposits include the Boundary Ridge and Giraffe Creek Members of the Twin Creek Limestone and their equivalents.

The second marine invasion was terminated near the middle of the Callovian by the rise and enlargement of a large island in Montana that cut off marine waters from the north. South of this island, in very shallow, probably highly saline waters, was deposited unfossiliferous red even-bedded fine-grained sand, which thickens westward 100-1,000 feet (30.5-305 m) or more, and which extends from the Black Hills area southwestward through southern Wyoming and northernmost Utah into southeastern Idaho. Near Idaho Falls, the lower part of the sand was deposited along with some marine lime mud and sand. This marine facies thins eastward to near the western boundary of Wyoming, where bedded salt and gypsum were deposited at about the same stratigraphic position over a distance of several hundred miles from north to south. Evidently marine and lagoonal conditions persisted to the west in Idaho at the same time as red sand was being deposited farther east in highly saline or possibly in brackish waters and at the same time as light-colored crossbedded sand was being reworked by winds in the Colorado Plateau.

The third marine invasion into the western interior region took place apparently during the late middle to early late Callovian, in some places, immediately after deposition of red even-bedded sand and equivalent eolian sand, and in other places, after a brief interval of erosion. The sea extended eastward across northern Utah, southern Idaho, northern Colorado, and southern Wyoming into South Dakota. It may also, possibly, have extended northward from the Black Hills area into southern Saskatchewan, where it could be represented by all or part of the glauconitic deposits called the Roseray Formation (equals middle member of the Vanguard Formation). 
In this sea, highly glauconitic limy sand, sandy silt, some gypsum, and some limy mud (Curtis Formation and Pine Butte Member of the Sundance Formation) were deposited in very shallow water, as shown by the presence of Ostrea, Lopha, Lingula, and Meleagrinella. Such sediments in the San Rafael swell were overlain conformably and passed laterally southeastward into unfossiliferous chocolate-brown, red, or gray even-bedded sand, silt, and clay and locally some gypsum that were probably deposited in highly saline water of the same sea as the glauconitic sediments. Deposition of both the marine and highly saline water sediments was followed rather quickly by withdrawal of the sea completely from the western interior region and by an interval of erosion that lasted until early Oxfordian time.

The fourth marine invasion of the western interior region entered central Montana east of the Sweetgrass arch during the latest Callovian and possibly entered the Williston basin even earlier. During the early Oxfordian, the sea spread widely but not as far south in Utah as the preceding sea and apparently did not spread west of the Sweetgrass arch. At the end of the early middle Oxfordian, the sea withdrew northward into northern Wyoming and the Williston basin but spread westward in Montana at least as far as the Sawtooth Range south of Glacier Park. It persisted in Montana at least to the end of the Oxfordian. The sea was bounded on the west in central Idaho and possibly in westernmost Montana by a landmass that shed considerable clastic sediment eastward. This is shown by a change from mostly glauconitic, calcareous sand, sandy lime, and sandy silt in the west to mostly silt and clay on the east. The sea was shallow, as shown by the presence of Ostrae, Mytilus, and Meleagrinella and by abundant ripple marks and crossbedding. The presence of many wood fragments in the Swift Formation in western Montana indicates that the climate was probably warm and humid.

The northward withdrawal of the sea in Montana during the early middle Oxfordian was followed by a brief fifth marine invasion southward from Montana and northern Wyoming as far as northwestern Colorado and northeastern Utah. In this sea was deposited a thin unit (Windy Hill Member of the Sundance Formation) of yellowish-gray limy locally oolitic ripple-marked sand and a little gray to green mud that contains a few mollusks such as Ostrea. These marine sediments were deposited unconformably on the Redwater Shale Member of the Sundance Formation and conformably below the continental Morrison Formation. As they are not recognizable as a lithologic unit north of the Wind River Basin in central Wyoming, they presumably pass northward into the upper part of the Redwater Shale Member in northern Wyoming. 
During later Jurassic time, continental sediments (Morrison Formation) were deposited on flood plains and in lakes throughout much of the western interior region and in coal-forming swamps in Montana. Continental deposition began during the early or late Oxfordian in the southern part of the region, definitely during the late Oxfordian in the central part, probably as late as Kimmeridgian in northern Montana, and persisted in all parts at least through the Kimmeridgian. Sediments in the southern and central parts of the western interior region were derived from the south and west; in the northern part, they were derived from the east and west. Evidently, continental sedimentation began at about the same time as deposition of the marine Norphlet and Smackover Formations of the gulf region, and uplift of land areas from which the continental sediments were derived occurred at the same time as uplift of land areas that shed sediment southward into the Gulf of Mexico during late Oxfordian to Tithonian time.

The Jurassic ammonite succession in North America from Hettangian through early Bajocian time is essentially the same as that elsewhere in the world. Ammonite assemblages of late Pliensbachian Age are differentiated from north to south just as they are in Europe. Ammonite assemblages of middle Bajocian Age in the Pacific Coast region contain some genera that are known only from areas bordering the Pacific Ocean, but overall their generic resemblances to European ammonites are striking.

In contrast, from late Bajocian until the end of the Jurassic, marked differentiation of ammonite faunas took place from north to south. The ammonite successions in the gulf region and in the Pacific Coast region as far north as southern California remained closely similar to those in the Mediterranean region. The succession from northern California to northern Alaska became similar to that in northern Eurasia, although some mingling of genera of Boreal and Mediterranean affinities took place in California and Oregon. Such mingling, plus the presence of genera known only from the Western Hemisphere, or from areas bordering the Pacific Ocean, have aided greatly in making fairly accurate correlations of rocks in widely separated areas.

The differentiation of ammonite faunas from north to south can be reasonably ascribed to partial isolation of an Arctic sea from the Pacific Ocean except for at least one connection through Yukon Territory during Middle and most of Late Jurassic time and for another connection from East Greenland to northwest Europe from the beginning of Callovian time (late Middle Jurassic) into Cretaceous time. 


\section{THE MAGOFFIN MEMBER OF THE BREATHITT FORMATION ${ }^{2}$}

\section{By W. F. Outerbridge}

Morse (1931, p. 301) gave the name Magoffin Beds to a sequence of marine limestone and shale in the middle part of what is now called the Breathitt Formation (Middle Pennsylvanian) of eastern Kentucky. The sequence was described from outcrops in Magoffin County at the head of Sycamore Branch of Oakley Creek, about $5.5 \mathrm{~km}(3.4$ miles) south-southeast of Royalton, Salyersville South 71/2-minute quadrangle, Kentucky. The sequence has been recognized by many geologists as an informal unit, the "Magoffin Beds of Morse (1931)." The base of the unit has been mapped throughout eastern Kentucky; because of its persistence, it is one of the most useful stratigraphic horizons for mapping and correlation in the Breathitt. This paper redefines and designates the Magoffin a member of the Breathitt Formation and describes a reference section that illustrates the chief features of the member.

The member is generally composed of an upward-coarsening sequence of shale, siltstone, and sandstone that contains marine fossils, mostly brachiopods, pelecypods, and gastropods. Lenses of fossil fragmental limestone are found near the base; lenses of micritic concretionary limestone occur higher in the shale. The basal contact is sharp and is placed at the base of fossiliferous carbonaceous to bituminous clay to silty clay shale that generally overlies coal, underclay, or sandstone. The upper contact, a disconformity, is placed where even-bedded siltstone and sandstone of the member are overlain by crossbedded channel-fill sandstone or by a coal bed. The member is as much as $60(200 \mathrm{ft})$ thick near Pine Mountain and thins northward to a featheredge generally north of Pike, Floyd, Magoffin, and Morgan Counties. The upper part of the member locally includes a thin informal unit, the Salt Lick Beds of Morse (1931, p. 303), described as about $2.2 \mathrm{~m}(7.2 \mathrm{ft})$ of fossiliferous limestone and shale. The limestone is micritic and is fossiliferous only locally.

The Magoffin Member is above the Copland (Taylor) coal bed and below the Hazard (Winifrede) coal zone. The Fire Clay coal bed, which has a distinctive flint clay parting, is about $35 \mathrm{~m}(115 \mathrm{ft})$ below the Magoffin Member in the area of the reference section.

Faunal evidence indicates that the Magoffin Member is of latest Morrowan to earliest Atokan age (Mackenzie Gordon, Jr., written commun., 1974). Limestone of the Magoffin Member is equivalent to the Winifrede Limestone of West Virginia and to the Upper Mercer Limestone of Ohio and Pennsylvania (Wanless, 1946, p. 145).

${ }^{2}$ Work done in cooperation with the Kentucky Geological Survey. 


\section{Measured section}

[Reference section of the Magoffin Member of the Breathitt Formation. Section measured in Floyd County on the south side of the gap between Raccoon Branch and Grassy Creek on the east side of Kentucky Route 7, in the southeastern part of the David 71/2 minute quadrangle, Kentucky]

Pennsylvanian:

Breathitt Formation (incomplete);

Sandstone, medium-gray $(N 5)^{1}$, massive, cross-laminated, not measured.

Magoffin Member:

7. Siltstone and sandstone interbedded in sets 0.1 to 0.01 m thick; siltstone, medium-dark-gray $(N 4)$; weathers medium gray $(N 5)$; micaceous, with some carbonaceous plant debris makes up all of lowest $1.5 \mathrm{~m}$ of unit. Sandstone, medium-gray ( $N 5$ ); weathers medium light gray ( $N$ 6; laminated to thin bedded, even bedded; very fine grained, mostly quartz and some feldspar, dark minerals, and grains of carbonaceous material

6. Limestone, dark-gray ( $N 3$ ); weathers medium dark gray ( $N 4$ ); concretionary, micritic; in lenticular bodies $1 \mathrm{~m}$ ( $3 \mathrm{ft})$ across, $0.4 \mathrm{~m}(1.3 \mathrm{ft})$ thick; contains some silt and clay. No fossils seen _......... $0-0.4$

5. Shale, medium-dark-gray ( $N$ 4); weathers medium gray ( $N 5$ ), clayey to silty, micaceous; contains grains of carbonaceous material; shell material in lower part

4. Limestone, medium-dark-gray $(N \quad 4)$; weathers medium gray $(N 5)$, concretionary, micritic, in lenticular bodies; contains as much as 30 percent clay and silt, and minor amounts of pyrite; contains spiny brachiopods

3. Shale, medium-dark-gray $(N 4)$; weathers medium gray ( $N 5)$; clayey to silty, micaceous; contains grains of carbonaceous material; fossiliferous, mostly broken brachiopod shells

2. Limestone, silty, grayish-black ( $N 2)$; weathers dark gray ( $N$ 3); even bedded; carbonaceous, contains about 50 percent silt and clay, and abundant coarse fossil debris, mostly crinoid parts

1. Shale, grayish-black ( $N 2)$; weathers grayish black $(N$ 2); silty, carbonaceous, pyritic; fossiliferous, brachiopods and some Lingula forms ........... Total Magoffin Member

Coal, Taylor coal bed 


\title{
REVISION OF CRETACEOUS NOMENCLATURE OF THE NORTHERN GREAT PLAINS IN MONTANA, NORTH DAKOTA, AND SOUTH DAKOTA
}

\author{
By Dudley D. Rice
}

As a result of regional surface and subsurface stratigraphic studies of the Cretaceous System of the northern Great Plains in Montana, North Dakota, and South Dakota, several changes in nomenclature are necessary to present the results of recent work and to facilitate future studies.

The Muddy Sandstone Member of the Thermopolis Shale is raised to formation rank in Montana. Because the name is widely used in the subsurface by petroleum geologists and because this sandstone, which is interpreted to be of marine origin, can be correlated with equivalent strata over Montana, North Dakota, and South Dakota both in the surface and in the subsurface, the name Muddy Sandstone is extended over most of the northern Great Plains. The Muddy Sandstone correlates with the Vaughn Member of the Blackleaf Formation on the Sweetgrass arch of northwestern Montana. The Vaughn Member consists of a basal massive arkosic sandstone, bentonitic and tuffaceous siltstone, and carbonaceous shale all of which are interpreted to be of nonmarine origin (Cobban and others, 1959, p. 2790-2791). In the vicinity of the Black Hills uplift, the Muddy Sandstone correlates with the Newcastle Sandstone, which consists of sandstone, carbonaceous siltstone, carbonaceous and bentonitic shale, and thin stringers and irregular beds of coal (Robinson and others, 1964, p. 44-45).

The Greenhorn Formation is extended to north-central and central Montana, where it includes the basal Mosby Sandstone Member and an upper unnamed calcareous shale member. The Mosby Sandstone Member correlates with the "Phillips sand" (economic term) of subsurface usage.

The name Warm Creek Shale, as named by Collier and Cathcart (1922, p. 172) and used by Knectel (1959, p. 740-741) in north-central Montana, is abandoned. This unit includes five formations that extend over most of the northern Great Plains. In ascending order, they are the Belle Fourche Shale, Greenhorn Formation, Carlile Shale, Niobrara Formation, and Telegraph Creek Formation.

The name Thermopolis Shale is geographically restricted from usage in Montana because it is used to include different strata, and it correlates with formations that have been mapped over the area. The Thermopolis Shale, as used by Knechtel (1959, p. 739-740) in northcentral Montana and by Richards (1955, p. 45-47) in south-central Montana, includes the Skull Creek Shale, Muddy Sandstone, and the 
basal part of the Mowry Shale. Roberts (1972, p. 16-17) included strata equivalent to the Fall River Sandstone, Skull Creek Shale, and Muddy Sandstone in the Thermopolis Shale of southwestern Montana.

The names Cloverly Formation and its Birdhead Sandstone Member, as used by Richards (1955, p. 42 45) in south-central Montana, are abandoned. The basal part of the unit correlates with the Kootenai Formation that extends over the entire State. The Kootenai Formation is unconformably overlain by the Fall River Sandstone that Richards (1955, p. 43) termed the Birdhead Sandstone Member.

The names Cut Bank, Sunburst, and Moulton are herein adopted as members of the Kootenai Formation (lower Cretaceous) in northwestern Montana.

The type section for the basal Cut Bank Sandstone Member is the Salt Dome No. 1 Krueger well, NW1/4 SW $1 / 4$ sec. 12 , T. 37 N., R. 5 W., Glacier County, Mont. from 2,571 to 2,642 feet $(748 \mathrm{~m}$ to $805 \mathrm{~m}$ ) as defined by Oakes (1966, p. 196). The member consists of a well-sorted sandstone usually divided into two benches by a mudstone.

The type section for the Sunburst Sandstone Member is the Johnson No. 1 Johnson " $D$ " well, NW1/4NW"1/4 sec. 32 , T. 35 N., R. 1 W., Toole County, Mont., on the Kevin-Sunburst dome, from 1,220 to 1,245 feet $(372 \mathrm{~m}$ to $380 \mathrm{~m}$ ). The member consists of a medium- to coarse-grained white to tan sandstone containing scattered multicolored chert grains. An abundance of white bentonite clay cement controls porosity of the Kevin-Sunburst field (Perry, 1928, pl 14). In the Cut Bank area, the upper part of the Sunburst is a bright red partially mottled mudstone. In the type area, the Sunburst Sandstone Member unconformably overlies the Upper Jurassic Swift or Morrison Formations.

The type section for the Moulton Member is the Montana Power No. 4 Farbo well, NW1/4SE1/4 sec. 3, T. 37 N., R. 4 W., Glacier County, Mont., from 2,388 to 2,485 feet $(728 \mathrm{~m}-757 \mathrm{~m})$ as defined by Oakes (1966, p. 197-198). The member consists of siltstone, carbonaceous shale, and mudstone with thin sandstones. The basal part contains a marl and (or) calcareous siltstone which forms an excellent marker bed containing freshwater ostracodes, pelecypods, and gastropods.

\section{AGE OF THE MOUNT PRINCETON QUARTZ MONZONITE IN CENTRAL COLORADO}

By G. R. Scott, R. E. VAN Alstine, and W. H. Sharp

The Mount Princeton Quartz Monzonite is considered by Priestly Toulmin, III (oral commun., 1974), to be slightly older than the Wall Mountain Tuff, which has a radiometric age of 35 m.y.-36 m.y. Until 
the radiometric age of the Mount Princeton is available, it is assigned an age of Eocene(?) to Oligocene(?). The age change is shown on U.S. Geological Survey Miscellaneous Field Studies Maps MF-657 and MF-658 (Scott, 1975; Scott and others, 1975).

\title{
REINST ATEMENT OF THE NAME CAPE FEAR FORMATION IN NORTH AND SOUTH CAROLINA
}

\author{
By Norman E. SOHL
}

The lowermost units of the outcropping Cretaceous sequence of the Carolinas have a complex nomenclatorial history which has been dealt with in detail by Heron (1958). Neither the extension of the term Patuxent (Stephenson, 1912) southward from Virginia nor the extension of the Tuscaloosa (Cooke, 1936) from Alabama and Georgia into the Carolinas to encompass both the Cape Fear and Middendorf Formations appears justifiable. Geologists such as Heron and Wheeler (1964) and others have presented sufficient evidence to indicate that the Cape Fear and Middendorf are lithically distinct and belong to separate sedimentological episodes.

The name Cape Fear Formation was first used by Stephenson in 1907 (p. 95-96) for exposures of the basal Cretaceous rocks exposed along the Cape Fear River between "one and one-half miles above the mouth of Little River in Harnett County and Devanes Ferry, 17 miles below Fayetteville," North Carolina. The formation consists dominantly of gray sandstones and interbedded mudstone that weather to a mottled red. Stephenson (1907, p. 95) estimated the total thickness on the outcrop to be 300 feet. It has been mapped as the lower part of the "Tuscaloosa Formation" in updip sections of Moore County, N.C., by Conley (1962). At its base, the formation rests upon the Piedmont complex. On the Cape Fear River, the formation is overlain unconformably by the Black Creek Formation (Stephenson, 1912, p. 92, Heron and Wheeler 1964, p. 41). In updip areas, it is unconformably overlain by the Middendorf Formation. The Cape Fear Formation has yielded no fossils of definitive age but has generally been assigned to the Early Cretaceous on indirect evidence. The overlying Middendorf Formation bears a leaf flora that has been correlated with the Black Creek Formation and a pollen flora correlated with the Magothy Formation, suggesting a late Austinian-early Taylorian age. A poorly known microfauna of Woodbinian to basal Austinian age has been reported from the "Tuscaloosa" of South Carolina (Siple and others, 1956), but whether the level represents a Cape Fear equivalent or the Middendorf is not known. Thus, at present, one can only consider the type Cape Fear as pre-late Austinian in age. 


\title{
THE EMPEROR VOLCANIC COMPLEX OF THE EAST GOGEBIC RANGE, MICHIGAN
}

\author{
By Virgil A. Trent
}

Diverse Precambrian X volcanic rocks formerly classified as "Huronian volcanics" and "greenstone conglomerate and eruptives" in older reports of the Lake Superior district have been mapped in detail at the eastern end of the Gogebic Iron Range in northern Michigan. Irving (1890) summarized the extent of the "Huronian" greenstone and greenschist occurrences in the Lake Superior region in the preface to a detailed petrographic study of similar volcanic rocks from the Menominee and Marquette Range areas. Irving noted that the eastern Gogebic Range contains an extraordinary quantity of fragmental rocks. The East Gogebic Range volcanic rocks intertongue with and overlie members of the Ironwood Iron-formation which is classified as Precambrian X. Because neither of these rock sequences has been dated radiometrically and because the volcanic rocks are coeval with the iron-formation, the volcanic rocks are also classified Precambrian X.

The volcanic rocks in the Gogebic Range crop out sporadically and have many interesting lithologies and structures, including a swarm of mafic dikes and a thick sill, which I interpret to be the feeders. Van Hise presented an essentially accurate description of the broad stratigraphic relations of these rocks (Irving and Van Hise, 1892, p. 430-437; Van Hise, 1893). The purpose of this paper is to name this assemblage of rocks the Emperor Volcanic Complex and to distinguish within the complex a sequence of flow breccias to be named the Wolf Mountain Creek Formation.

Regional geologic studies and mapping upon which this report is based (Trent, 1973a, b; V. A. Trent, in U.S. Geol. Survey, 1973, p. 41) indicate that the Gogebic Range was a volcanic province during the greater part of Precambrian time. Superposed Precambrian W, X, and $\mathrm{Y}$ lavas and associated metasedimentary and intrusive rocks were subjected to three periods of major deformation (Trent, 1972) that resulted in prominent fold, fault, and joint formation and superimposed metamorphic grades. Specific field data document Van Hise's (1893) original discovery of a volcanic center in the Gogebic Range and further suggest that older and younger volcanic centers were nearby (Trent, 1973a; and W. C. Prinz, written commun. 1973).

The Precambrian rocks probably accumulated in a shallow-water marine environment, possibly associated with an island arc. Such an environment is suggested by pillow structures present at one place or another in all the Precambrian lavas and by ripple-marked bedding 
planes, algal structures, and scour fillings in metasedimentary rocks. An island-arc setting is inferred by the similarity of the rock suite to that of present-day island arcs.

\section{EMPEROR VOLCANIC COMPLEX}

A volcanic rock assemblage composed mainly of basalt flows intertongued with and overlying the lower members of the Ironwood Ironformation, a widespread flow-breccia unit, and intrusive rocks that include mafic dikes, phacoliths, and a thick mafic sill are herein named the Emperor Volcanic Complex. This unit is named from Emperor Creek, a tributary of the Little Presque Isle River that crosses Emperor rocks in secs. 14 and 15, T. 47 N., R. 44 W. Basalt flows are intermittent in the lower beds of the Ironwood Iron-formation and become more numerous upwards in the section, in effect diluting the iron-formation strata and finally overlapping them along the north limb of a large asymmetrical anticline, the Wolf Mountain anticline, in T. 47 N., R. 44 W. (Trent, 1973a). Intercalated Emperor-Ironwood strata are overlain by the Copps Formation of Allen and Barrett (1915, p. 54-57; herein adopted for U.S. Geological Survey usage) and underlain by the Palms Formation of the Gogebic Range. The type locality of the Emperor Volcanic Complex is in exposures north and west of the Kimberly Clark logging road, which runs east to northnortheast through sections 21,22 , and sec. 15 , T. 47 N., R. 44 W., in the Wakefield NE 71/2-minute quadrangle (Trent, 1973a). A reference section is found along the "mine road" in sections $28,29,20$, and 21, T. 47 N., R. 43 W., Marenisco Township, Gogebic County, Mich.

\section{WOLF MOUNTAIN CREEK FORMATION}

A conspicuous flow-breccia unit that crops out chiefly in the nose of a large Penokean fold is herein named the Wolf Mountain Creek Formation. This unit is named after Wolf Mountain Creek, another tributary to the Little Presque Isle River, which traverses sections 22, 23, and 24, T. 47 N., R. 44 W., in the Wakefield NE quadrangle. The Wolf Mountain Creek Formation appears to be overlain by the Copps Formation (Allen and Barrett, 1915, p. 54-57) and is underlain by intertongued basalt flows and lower members of the Ironwood Iron-formation. The Wolf Mountain Creek Formation adjoins a thick mafic sill, at the extrusion site in the SW $1 / 4$ sec. 15 , T. 47 N., R. 44 W., which I interpret to be the feeder to this formation. Outcrops of the Wolf Mountain Creek Formation overlie the intertongued section of the Emperor Volcanic Complex and therefore are the youngest rocks in the complex. The type locality for the Wolf Mountain Creek For- 
mation is the large flow-breccia outcrop area(s) that flank Wolf Mountain Creek to the north and south in secs. 14, 23, 24, and 25, T. 47 N., R. 44 W., in the Wakefield NE quadrangle. A reference section is $150 \mathrm{~m}$ north of the end of the "mine road" in secs. 20 and 21, T. 47 N., R. $43 \mathrm{~W}$.

\section{GEOGRAPHIC EXTENT (SEE TRENT, 1973a)}

The Emperor Volcanic Complex crops out primarily east and west of the Little Presque Isle River in Wakefield Township, T. 47 N., R. 44 W., secs. 14-18 and 22-27, Gogebic County, Mich. Less numerous outcrops are to the east in Marenisco Township, T. 47 N., R. 43 W., in secs. 19-21, 28-30, and in a single outcrop of greenstone near the terminus of the Gogebic Iron Range in section 23. Mafic dikes interpreted to be feeders crop out mostly in older basement rocks in T. 46 N., R. $43-45 \mathrm{~W}$. A thick metadiabase dike is present in secs. 6 and 1 , T. 46 N., R. 44-45 W. The same dike crops out farther southwest outside the study area toward county highway 519 in sec. 9, T. 46 N., R. $45 \mathrm{~W}$., where it approaches a thickness of $150 \mathrm{~m}$ in the Wakefield $71 / 2$-minute quadrangle. One small pendant of veined Emperor lava, $30 \mathrm{~cm}$ square, was found in granite about $6.5 \mathrm{~km}$ south of the main outcrop belt in sec. 10 , T. 46 N., R. $44 \mathrm{~W}$.

\section{REFERENCES-ORIGINAL AND UPDATED}

The first systematic studies of the geology of the Gogebic Iron Range were carried out by the Michigan and Wisconsin Geological Surveys. Then, in the late 1800 's, a more detailed field and laboratory study by Irving and Van Hise (1892), was published by the U.S. Geological Survey, the first in a series of monographs on the ironbearing rocks of the Lake Superior region. This is the original reference describing these volcanic rocks and the best published description to date. The eastern part of the range was treated in a separate chapter because of structural and stratigraphic complications associated with the volcanic center. The map accompanying the report was the first to show the southward divergence of "Huronian" strata from the Keweenawan rocks along the limb of a major Penokean fold.

The U.S. Geological Survey began geologic mapping in the area again in 1962. An economic assessment of the beneficiation characteristics of the iron-formation in several sections of T. 47 N., R. 44 W., was compiled by Prinz (1967) from aerial mapping, ground-magnetic surveying, and company exploration data. The most complete up-todate geologic map of the area and the basis of this report was compiled from mapping by Prinz and Trent (Trent, 1973a, b). 


\section{LITHOLOGIC CHARACTERISTICS}

The Emperor Volcanic Complex is a heterogeneous rock assemblage composed mainly of basalt flows intertongued with and overlying the lower members of the Ironwood Iron-formation. Also included in the complex are intrusive rocks that were probably in part the feeders. They are a mafic dike swarm roughly $12 \mathrm{~km}$ wide and several thick mafic phacoliths and a thick mafic sill that broke out on a shallow sea floor. Finally, there is a widespread flow-breccia unit included in the complex, the Wolf Mountain Creek Formation, that adjoins the sill in a zone of transition rocks and chaotic structure at the extrusive center. The above-mentioned rocks, with the exception of the dikes, crop out largely in T. 47 N., R. 44 W., in the faulted limb of the Wolf Mountain anticline (Trent, 1973a) and eastward to the end of the Gogebic Iron Range in NW1/4 sec. 23, T. 47 N., R. 43 W., where a single outcrop of metamorphosed flow breccia (greenschist) is found.

Generally, the lower basalt flows in the Emperor Volcanic Complex are not notably amygdaloidal, but several of the upper flow units contain large amygdules, $2-15 \mathrm{~cm}$ in diameter, filled with chert, jasper, and quartz. The basalt flows are medium dark gray to medium light gray, generally having a greenish hue. The individual flows may also grade upward from darker to lighter shades of color. Flow thicknesses are variable from 10 to $120 \mathrm{~m}$, and in contrast to older and younger Precambrian basalt flows in the area, these are not clearly pillow structured. One basalt outcrop has questionable pillow structure and a veined polygonal joint system. Silicic fluid injections fill tension joints in the basalt flows increasingly toward the volcanic center in the eastern part of T. 47 N., R. $44 \mathrm{~W}$. An apophyse or vein of granitic-like rock fills a tension joint in a metamorphosed basalt flow in sec. 16, T. $47 \mathrm{~N}$., R. $44 \mathrm{~W}$., $0.8 \mathrm{~km}(1 / 2 \mathrm{mi})$ southwest of the eruptive center. The vein material contains quartz, calcite, coarse-bladed crystal aggregates of ferroaxinite, and sparse amounts of magnetite, epidote, and base-metal sulfides. Axinite is a relatively rare borosilicate mineral group generally considered to be of pneumatolytichydrothermal origin (V. A. Trent, in U.S. Geol. Survey, 1973, p. 41; V. A. Trent, M. E. Mrose, and F. W. Brown, unpub. data, 1976).

Mafic dikes are very common in the Precambrian W crystalline rocks of the East Gogebic Range and may be classified broadly into two groups, older and younger. The older dikes are interpreted to be conduits for the extrusive and intrusive Emperor volcanic rocks, whereas the younger diabase dikes probably are related to Keeweenawan volcanism (Schmidt and Trent, 1969). The older metagabbro, metadolerite, and metadiabase dikes are hornblende rich, contain sparse disseminated sulfides, and have been 
metamorphosed to the upper greenschist facies. The dikes are 3-180 $m$ thick. Many well-defined younger diabase dikes crop out within older metagabbro dikes, and both types of dike are largely joint controlled. A thick metadolerite dike that crops out in secs. 6 and 1, T. 47 N., R. 44 and 45 W., and farther southwest may be a feeder for the thick metagabbro and metadiorite sill and several large mafic phacoliths. The phacolithic bodies that crop out in secs. $22,25,26$, and 27, T. 47 N., R. 44 W., and that form conspicuous topographic cuestas, such as Wolf Mountain in sec. 26 and a hill in sec. 27, were probably injected into the iron-formation strata of the Wolf Mountain anticline during the late dilational stages of fold development. The phacoliths are typically metagabbro or metabasalt and range in thickness from 120 to $180 \mathrm{~m}$. The intrusive rocks of the Emperor Volcanic Complex generally range in color from medium dark to medium light gray, and dark greenish gray to light greenish gray.

A metagabbro, metadiorite, and metadiabase feeder sill 150-300 m thick crops out for $4.8 \mathrm{~km}$ west-northwest of the volcanic center in secs. $16,17,18$, and 7, T. 47 N., R. 44 W., and in sec. 12 , T. 47 N., R. 45 W., where it is truncated by a Keweenawan unconformity (Prinz, 1967). Holocrystalline texture predominates in most of the sill exposures; however, eastward in sec. 16 , rock texture is transitional to aphanitic phases characteristic of extrusive rocks.

The mafic sill grades directly through a transition rock zone into the extrusive rock sequence of the Wolf Mountain Creek Formation at the volcanic center in the SW1/4 sec. 15 , T. 47 N., R. 44 W. Pyroclastic flow breccia, tectonic flow breccia, and veined amygdaloidal lavas are typical rocks in the Wolf Mountain Creek Formation, which is 90-150 m thick. Volcanic-clastic rocks intercalated in the formation as beds and screens are locally cross stratified and contain substantial amounts of tuff-forming tuff-breccias. Amygdaloidal flows are dark greenish gray to light greenish gray, and individual flows may grade upwards from dark to lighter color. Flow breccia usually has greenish-gray clasts in a medium-gray matrix; sporadically, the clasts are darker than the matrix. Weathered surfaces of the flow breccia are commonly olive gray. A dacitic flow cropping out near the volcanic center is medium light greenish-gray to light greenish-gray. East of the eruptive center in secs. 14 and 23, about $90 \mathrm{~m}$ of pillow agglomerate was deposited, which typically has undergone massive tension fracturing due to doming forces. The flows are commonly amygdaloidal and scoriacious in the Wolf Mountain Creek Formation and generally in outcrop appear to be "breaking-apart upwards," resulting in a jumbled mass of large to small breccia fragments. After these autoclastic rocks (Van Hise, 1896, p. 625-627) are broken they are difficult to distinguish from true pyroclastic fragmental rocks. 
The most silicic rock observed in the formation is a porphyritic dacite that crops out in sec. 15 , T. 47 N., R. 44 W., near the volcanic center. A bulk sample of the flow was collected for radiometric dating, but laboratory studies showed that the rock lacked sufficinet zircons for age determination (Philip Banks, written commun., 1972).

The phenomena responsible for the large variety of textures and structures in the rocks of the Emperor Volcanic Complex are hypabyssal conditions in and adjacent to volcanoes, extrusive conditions common to the formation of flow breccias and lavas, and several episodes of metamorphic alteration. Several types of metamorphic and primary structures have been preserved in the basalt flows and the rocks of the Wolf Mountain Creek Formation. Some of these are pillow structures; true spheroidal jointing, which may be confused with pillow structure under conditions of obscure rock exposure; polygonal (columnar) jointing; veined rocks denoting a tectonic environment; and slaty and fracture cleavage which distinguish metamorphosed sedimentary from intrusive rocks.

\section{STRATIGRAPHIC RELATIONS AND CORRELATION}

A multifacies clastic unit, the Copps Formation (Allen, and Barrett, 1915, p. 54-57), overlies the Emperor rocks in the East Gogebic Range. Members of the Ironwood Iron-formation are lateral equivalents of the Emperor because of an intertonguing relationship (Trent, 1973a). Stratigraphically underlying the Emperor-Ironwood beds is the Palms Formation of the East Gogebic Range.

The extrusive rocks of the Emperor Volcanic Complex probably correlate with the Hemlock Formation of the Crystal Falls, Mich., area (James, 1958, p. 36; Clements and Smyth, 1899, p. 135-136) and with the Clarksburg Volcanics Member of the Michigamme Slate of the Marquette Range, Mich.

\section{REFERENCES CITED}

Adkison, W. L., 1975, West Foreland and Tyonek Formations at Capps Glacier, in Yount, M. E., ed., United States Geological Survey Alaska Program, 1975: U.S. Geol. Survey Circ. 722, p. 45.

Alaska Geological Society, 1970, Oil and gas fields in the Cook Inlet basin, Alaska: Anchorage, Alaska, $84 \mathrm{p}$.

Allen, R. C., and Barrett, L. P., 1915, Contributions to the Precambrian geology of northern Michigan and Wisconsin: Michigan Geol. Survey Pub. 18 (Geol. Ser. 15), p. 13-164.

Anderson, A. L., 1961, Geology and mineral resources of the Lemhi quadrangle, Lemhi County: Idaho Bur. Mines and Geology Pamph. 124, $111 \mathrm{p}$.

Armstong, A. K., 1955, Preliminary observations on the Mississippian system of northern New Mexico: New Mexico Bur. Mines and Mineral Resources Circ. 39, $42 \mathrm{p}$.

1967, Biostratigraphy and carbonate facies of the Mississippian Arroyo Peñasco 
Formation, north-central New Mexico: New Mexico Bur. Mines and Mineral Resources Mem. 20, 81 p.

Armstrong, A. K., and Mamet, B. L., 1974, Biostratigraphy of the Arroyo Penasco Group, lower Carboniferous (Mississippian), north-central New Mexico: New Mexico Geol. Soc. Guidebook, 25th Field Conf., Ghost Ranch, p. 145-158.

Ashley, R. P., 1974, Goldfield mining district [Nevada], in Guidebook to the geology of four Tertiary volcanic centers in central Nevada: Nevada Bur. Mines and Geology Rept. 19, p. 49-66.

Austin, G. S., 1969, Paleozoic lithostratigraphic nomenclature for southeastern Minnesota: Minnesota Geol. Survey Inf. Circ. 6, 11 p.

Averitt, Paul, 1941, The Early Grove gas field, Scott and Washington Counties, Virginia: Virginia Geol. Survey Bull. 56, 50 p.

Bartlett, C. S., Jr., 1967, Geology of the Southern Pines quadrangle: Chapel Hill, N.C., Univ. North Carolina, unpub. M.S. thesis, $101 \mathrm{p}$.

Beikman, H. M., compiler, 1974, Preliminary geologic map of the southeast quadrant of Alaska: U.S. Geol. Survey Misc. Field Studies Map MF-612, 2 sheets.

1975, Preliminary geologic map of the Alaska Peninsula and Aleutian Islands: U.S. Geol. Survey Misc. Field Studies Map MF-674, 2 sheets.

Bell, Henry, III, Butler, J. R., Howell, D. E., and Wheeler, W. H., [1974], Geology of the Piedmont and Coastal Plain near Pageland, South Carolina, and Wadesboro, North Carolina, in Carolina Geol. Soc. Guidebook [1974]: Columbia, S.C., South Carolina Div. Geology, $23 \mathrm{p}$.

Best, M. G., Shuey, R. T., Caskey, C. F., and Grant, S. K., 1973, Stratigraphic relations of members of the Needles Range Formation at type localities in southwestern Utah: Geol. Soc. America Bull., v. 84, no. 10, p. 3269-3278.

Black, D. F. B., 1974, Geologic map of the Winchester quadrangle, Clark and Madison Counties, Kentucky: U.S. Geol. Survey Geol. Quad. Map GQ-1159.

Bowen, Z. P., 1966, Brachiopods and stratigraphy of the Elbow Ridge Sandstone (Lower Devonian) of Pennsylvania, Maryland, and West Virginia: Jour. Paleontology, v. 40, no. 5, p. 1051-1062.

1967, Brachiopoda of the Keyser Limestone (Silurian-Devonian) of Maryland and adjacent areas: Geol. Soc. America Mem. 102, 103 p.

Bushman, A. V., 1973, Pre-Needles Range silicic volcanism, Tunnel Spring Tuff (Oligocene), west-central Utah: Brigham Young Univ. Geol. Studies, v. 20, pt. 4, p. $159-190$.

Butts, Charles, 1933, Geologic map of the Appalachian Valley of Virginia with explanatory text: Virginia Geol. Surv. Bull. 4256 p., 1 pl.

1940, Geology of the Appalachian Valley in Virginia: Virginia Geol. Surv. Bull. 52 , pt. 1,568 p.

Byers, F. M., Jr., Carr, W. J., Orkild, P. P., Quinlivan, W. D., and Sargent, K. A., 1976, Volcanic suites and related cauldrons of Timber Mountain-Oasis Valley caldera complex, southern Nevada: U.S. Geol. Survey Prof. Paper 919 (in press).

Calderwood, K. W., and Fackler, W. C., 1972, Proposed stratigraphic nomenclature for Kenai Group, Cook Inlet Basin, Alaska: Am. Assoc. Petroleum Geologists Bull., v. 56, no. 4, p. $739-754$.

Christiansen, R. L., 1974, Geologic map of the West Thumb quadrangle, Yellowstone National Park, Wyoming: U.S. Geol. Survey Geol. Quad. Map GQ-1191.

1975 , Geologic map of the Norris Junction quadrangle, Yellowstone National Park, Wyoming: U.S. Geol. Survey Geol. Quad. Map GQ-1193.

Christiansen, R. L., and Blank, H. R., Jr., 1974a, Geologic map of Old Faithful quadrangle, Yellowstone National Park, Wyoming: U.S. Geol. Survey Geol. Quad. Map GQ-1189.

1974b, Geologic map of the Madison Junction quadrangle, Yellowstone National 
Park, Wyoming: U.S. Geol. Survey Geol. Quad. Map GQ-1190.

Clements, J. M., and Smyth, H. L., 1899, The Crystal Falls iron-bearing district of Michigan: U.S. Geol. Survey Mon. 36, 512 p.

Cobban, W. A., Erdmann, C. E., Lemke, R. W., and Maughan, E. K., 1959, Revision of Colorado Group on Sweetgrass arch, Montana: Am. Assoc. Petroleum Geologists Bull., v. 43 , no. 12 , p. $2786-2796$.

Collier, A. J., and Cathcart, S. H., 1922, Possibility of finding oil in laccolithic domes south of the Little Rocky Mountains, Montana: U.S. Geol. Survey Bull. 736-F, p. 171-178.

Conley, J. F., 1962, Geology and mineral resources of Moore County, North Carolina: North Carolina Div. Mineral Resources Bull. 76, 40 p., 8 pls.

Cooke, C. W., 1936, Geology of the Coastal Plain of South Carolina: U.S. Geol. Survey Bull. 867, $196 \mathrm{p}$.

Cooke, C. W., and MacNeil, F. S., 1952, Tertiary stratigraphy of South Carolina: U.S. Geol. Survey Prof. Paper 243-B, p. 19-29.

Cooper, G. A., and Dutro, J. T., Jr., 1974, Devonian Brachiopoda of New Mexico, in Geological Survey research 1974: U.S. Geol. Survey Prof. Paper 900, p. 39-40.

Cornwall, H. R., and Krieger, M. H., 1975, Geologic map of the Grayback quadrangle, Pinal County, Arizona: U.S. Geol. Survey Geol. Quad. Map GQ-1206, 2-p. text.

Crandell, D. R., and Miller, R. B., 1974, Quaternary stratigraphy and extent of glaciation in the Mount Rainier region, Washington: U.S. Geol. Survey Prof. Paper 847, $59 \mathrm{p}$.

Crosthwaite, E. G., 1974, A progress report on results of test-drilling and ground-water investigations of the Snake Plain aquifer, southeastern Idaho; Part 3, Lake Walcott-Bonanza Lake area: Idaho Dept. Water Resources Water Inf. Bull. 38, $25 \mathrm{p}$.

Dall, W. H., 1919, Mollusks, Recent and Pleistocene: Canadian Arctic Exped., 19131918, Rep., v. 8, pt. A, 29 p.

1920, Pliocene and Pleistocene fossils from the Arctic coast of Alaska and the auriferous breaches of Nome, Norton Sound, Alaska: U.S. Geol. Survey Prof. Paper 125 , p. $23-37$.

Deiss, C. F., 1938, Cambrian formations and sections in part of Cordilleran trough: Geol. Soc. America Bull., v. 49, no. 7, p. 1067-1168.

Dennison, J. M., 1970, Stratigraphic divisions of Upper Devonian Greenland Gap Group ("Chemung Formation") along Allegheny Front in West Virginia, Maryland, and Highland County, Virginia: Southeastern Geology, v. 12, no. 1, p. 53-82.

Detterman, R. L., Reiser, H. N., Brosgé, W. P., and Dutro, J. T., Jr., 1975, PostCarboniferous stratigraphy, northeastern Alaska: U.S. Geol. Survey Prof. Paper $886,46 \mathrm{p}$.

de Witt, Wallace, Jr., 1974, Geologic map of the Beans Cove and Hyndman quadrangles and part of the Fairhope quadrangle, Bedford County, Pennsylvania: U.S. Geol. Survey Misc. Geol. Inv. Map I-801, text 6 p.

Dott, R. H., Jr., 1955, Pennsylvanian stratigraphy of Elko and northern Diamond Ranges, northeastern Nevada: Am. Assoc. Petroleum Geologists Bull., v. 39, no. 11 , p. 2211-2305.

Dover, J. H., and Ross, R. J., Jr., 1975, Ordovician and Middle Silurian rocks of the Wildhorse window, northeastern Pioneer Mountains, central Idaho: U.S. Geol. Survey Jour. Research, v. 3, no. 4, p. 431-436.

Duffield, W. A., and Sharp, R. V., 1975, Geology of the Sierra foothills melange and adjacent areas, Amador County, California: U.S. Geol. Survey Prof. Paper 827, $30 \mathrm{p}$.

Dyson, J. L., 1967, Geology and mineral resources of the southern half of the new 
Bloomfield quadrangle, Pennsylvania: Pennsylvania Geol. Survey, 4th ser., Atlas A-137ed, 86 p.

Ekren, E. B., Anderson, R. E., Rogers, C. L., and Noble, D. C., 1971, Geology of northern Nellis Air Force Base Bombing and Gunnery Range, Nye County, Nevada: U.S. Gol. Survey Prof. Paper 651, 91 p.

Elias, M. K., 1956, Upper Mississippian and Lower Pennsylvanian formations of south-central Oklahoma, in V. 1 of Ardmore Geol. Soc., Petroleum geology of southern Oklahoma-a symposium: Tulsa, Okla., Am. Assoc. Petroleum Geologists, p. 56-134.

Elias, M. K., and Branson, C. C., 1959, Type section of the Caney shale: Oklahoma Geol. Survey Circ. 52, 24 p.

Engels, J. C., 1975, Potassium-argon ages of the plutonic rocks, in Miller, F. K., and Clark, L. D., Geology of the Chewelah-Loon Lake area, Stevens and Spokane Counties, Washington: U.S. Geol. Survey Prof. Paper 806, p. 52-58.

Erickson, R. L., and Marsh, S. P., 1974, Geologic map of the Iron Point quadrangle, Humboldt County, Nevada: U.S. Geol. Survey Geol. Quad. Map GQ-1175.

Ernst, W. G., and Hall, C. A., Jr., 1974, Geology and petrology of the Cambria Felsite, a new Oligocene formation, west-central California Coast Ranges: Geol. Soc. America Bull., v. 85, no. 4, p. 523-532.

Fairbanks, H. W., 1904, Description of the San Luis quadrangle [California]: U.S. Geol. Survey Geol. Atlas, Folio 101, 14 p.

Flower, R. H., 1964, The nautiloid order Ellesmeroceratida (Cephalopoda): New Mexico Bur. Mines and Mineral Resources Mem. 12, 234 p.

1965, Early Paleozoic of New Mexico, in Guidebook of southwestern New Mexico II-New Mexico Geol. Soc., 16th Field Conf., 1965: Socorro, N. Mex., New Mexico Bur. Mines and Mineral Resources, p. 112-131.

Fox, K. F., Jr., and Rinehart, C. D., 1974, Comparison of Anarchist and Covada Groups of north-central Washington, in Geological Survey Research 1974; U.S. Geol. Survey Prof. Paper 900, p. 50-51.

Gair, J. E., 1975, Bedrock geology ahd ore deposits of the Palmer quadrangle, Marquette County, Michigan: U.S. Geol. Survey Prof. Paper 769, 159 p.

Goddard, E. N., and others, 1948, Rock-color chart: Washington, D.C., Natl. Research Council, 6 p. (Repub. by Geol. Soc. America, 1951, repr. 1963).

Gordon, Mackenzie, Jr., and Stone, G. C., 1976, Correlation of the Carboniferous rocks of the Ouachita trough with those of the adjacent foreland, in Symposium on the geology of the Ouachita Mountains: Little Rock, Ark., Arkansas Geol.Commission, v. 1 (in press).

Grabau, A. W., 1909, Physical and faunal evolution of North America during Ordovicic, Siluric, and early Devonic time: Jour. Geology, v. 17, p. 209-252.

Hail, W. J., Jr., 1974, Geologic map of the Rough Gulch quadrangle, Rio Blanco and Moffat Counties, Colorado: U.S. Geol. Survey Geol. Quad. Map GQ-1195.

Hall, C. A., 1974, Geologic map of the Cambria region, San Luis Obispo County, California: U.S. Geol. Survey Misc. Field Studies Map MF-599, 2 sheets.

Ham, W. E., and others, 1969, Regional geology of the Arbuckle Mountains, Oklahoma: Oklahoma Geol. Survey Guidebook 17, $52 \mathrm{p}$.

Hampton, E. R., 1974, Selenium in ground water widespread in southwestern Colorado, in Geological Survey research 1974: U.S. Geol. Survey Prof. Paper 900, p. 163-164.

Harlton, B. H., 1938, Stratigraphy of the Bendian of the Oklahoma salient of the Ouachita Mountains: Am. Assoc. Petroleum Geologists Bull., v. 22, no. 7, p. 852-914.

1956, The Harrisburg trough, Stephens and Carter Counties, Oklahoma, in V. 1 
of Ardmore Geol. Soc., Petroleum geology of southern Oklahoma-a symposium: Tulsa, Okla., Am. Assoc. Petroleum Geologists, p. 135-143.

1959, Age classification of the upper Pushmataha series in the Ouachita Mountains [Okla.], in Cline, L. M., Hilseweck, W. J., and Feray, D. E., eds., The geology of the Ouachita Mountains-a symposium: Dallas, Tex., Dallas Geol. Soc., and Ardmore Geol. Soc., p. 130-139.

Hatch, N. L., Jr., and Stanley, R. S., 1973, Some suggested stratigraphic relations in part of southwestern New England: U.S. Geol. Survey Bull. 1380, 83 p.

Hayes, P. T., assisted by Cone, G. C., 1975, Cambrian and Ordovician rocks of southern Arizona and New Mexico and westernmost Texas: U.S. Geol. Survey Prof. Paper $873,98 \mathrm{p}$.

Head, J. W., 1968, in Cleaves, E. G., Edwards, Jonathan, Jr., and Glaser, J. D., compilers and eds., Geologic map of Maryland: Baltimore, Md., Maryland Geol. Survey, scale 1:250,000.

Hereford, Richard, 1975, Chino Valley Formation (Cambrian?) in northwestern Arizona: Geol. Soc. America Bull., v. 86, no. 5, p. 677-682.

Heron, S. D., Jr., 1958, History of terminology and correlations of the basal Cretaceous formations of the Carolinas: South Carolina State Devel. Board, Div. Geology Bull., v. 2, no. 11-12, p. 77-88.

Heron, S. D., Jr., and Wheeler, W. H., 1964, The Cretaceous formations along the Cape Fear River, North Carolina: Atlantic Coastal Plain Geol. Assoc., 5th Ann. Field Excursion, Oct. 1964, Guidebook, 53 p. [Durham, N.C., Duke Univ.].

Herrmann, L. A., 1954, Geology of the Stone Mountain-Lithonia district, Georgia: Georgia Geol. Survey Bull. 61, 139 p.

Higgins, M. W., and Zietz, Isidore, 1975, Geologic interpretation of aeromagnetic and aeroradioactivity maps of northern Georgia: U.S. Geol. Survey Misc. Geol. Inv. Map I-783, 3 sheets.

Hinrichs, E. N., and Orkild, P. P., 1961, Eight members of the Oak Spring Formation, Nevada Test Site and vicinity, Nye and Lincoln Counties, Nevada: U.S. Geol. Survey Prof. Paper 424-D, p. D96-D103.

Hintze, L. F., 1951, Lower Ordovician detailed stratigraphic sections for western Utah: Utah Geol. Mineralog. Survey Bull. 39, 100 p.

1973, Lower and Middle Ordovician stratigraphic sections in the Ibex area, Millard County, Utah: Brigham Young Univ. Geology Studies, v. 20, pt. 4, p. 3-36. 1974a, Preliminary geologic map of The Barn quadrangle, Millard County, Utah: U.S. Geol. Survey Misc. Field Studies Map MF-633, 2 sheets.

1974b, Preliminary geologic map of the Conger Mountain quadrangle, Millard County, Utah: U.S. Geol. Survey Misc. Field Studies Map MF-634, 2 sheets.

1974c, Preliminary geologic map of the Crystal Peak quadrangle, Millard County, Utah: U.S. Geol. Survey Misc. Field Studies Map MF-635, 2 sheets.

$-1974 d$, Preliminary geologic map of the Notch Peak quadrangle, Millard County, Utah: U.S. Geol. Survey Misc. Field Studies Map MF-636, 2 sheets.

1974 e, Preliminary geologic map of the Wah Wah Summit quadrangle, Millard and Beaver Counties, Utah: U.S. Geol. Survey Misc. Field Studies Map MF-637, 2 sheets.

Hollingsworth, R. V., 1934, Union Valley sandstone [abs.]: Geol. Soc. America Proc. 1933 , p. $364-365$.

Hotz, P. E., 1974, Lower Paleozoic(?) sedimentary rocks in eastern Klamath Mountains [California], in Geological Survey research 1974: U.S. Geol. Survey Prof. Paper 900, p. 46.

Hubbard, H. A., 1975, Lower Keweenawan volcanic rocks of Michigan and Wisconsin:

U.S. Geol. Survey Jour. Research, v. 3, no. 5, p. 529-541.

Irving, R. D., 1890, Explanatory and historical note, in Williams, G. H., The 
greenstone schist areas of the Menominee and Marquette regions of Michigan: U.S. Geol. Survey Bull. 62, p. 11-30.

Irving, R. D., and Van Hise, C. R., 1892, The Penokee iron-bearing series of Michigan and Wisconsin: U.S. Geol. Survey Mon. 19, 534 p.

James, H. L., 1958, Stratigraphy of pre-Keweenawan rocks in parts of northern Michigan: U.S. Geol. Survey Prof. Paper 314-C, p. 27-44.

Jones, D. L., 1973, Structural elements and biostratigraphical framework of Lower Cretaceous rocks in southern Alaska, in The Boreal Lower Cretacous: Liverpool, England, Seel House Press, p. 1-18.

Knechtel, M. M., 1959, Stratigraphy of the Little Rocky Mountains and encircling foothills, Montana: U.S. Geol. Survey Bull. 1072-N, p. 723-752.

Krieger, M. H., 1974, Geologic map of the Crozier Peak quadrangle, Pinal County, Arizona: U.S. Geol. Survey Geol. Quad. Map GQ-1107, test $11 \mathrm{p}$.

Larsen, E. S., Jr., and Cross, Whitman, 1956, Geology and petrology of the San Juan region, southwestern Colorado: U.S. Geol. Survey Prof. Paper 258, 303 p.

Lerbekmo, J. F., Hanson, L. W., and Campbell, F. A., 1968, Application of particle size distribution to determination of source of a volcanic ash deposit: Internat. Geol. Cong., 23d, Prague, 1968, Proc., Sec. 2, p. 283-295.

Lindholm, G. F., Helgesen, J. P., Broussard, W. L., and Farrell, D. F., 1974, Water resources of the lower St. Croix watershed, east-central Minnesota: U.S. Geol. Survey Hydrol. Inv. Atlas HA-490, 3 sheets.

Lipman, P. W., 1975, Evolution of the Platoro caldera complex and related volcanic rocks, southeastern San Juan Mountains, Colorado: U.S. Geol. Survey Prof. Paper $852,128 \mathrm{p}$.

Lipman, P. W., Steven, T. A., and Mehnert, H. H., 1970, Volcanic history of the San Juan Mountains, Colorado, as indicated by potassium-argon dating: Geol. Soc. America Bull., v. 81, no. 8, p. 2329-2352.

Loney, R. A., Brew, D. A., Muffler, L. J. P., and Pomeroy, J. S., 1975, Reconnaissance geology of Chichagof, Baranof, and Kurzof Islands, southeastern Alaska: U.S. Geol. Survey Prof. Paper 792, 105 p.

Love, J. D., and Keefer, W. R., 1975, Geology of sedimentary rocks in southern Yellowstone National Park, Wyoming: U.S. Geol. Survey Prof. Paper 729-D, 60 p.

McCaleb, J. A., Quinn, J. H., and Furnish, W. M., 1964, The ammonoid family Girtyoceratidae in the southern midcontinent: Oklahoma Geol. Survey Circ. 67, 41 p.

McKee, E. D., 1975, The Supai Group—subdivision and nomenclature: U.S. Geol. Survey Bull. 1395-J, $11 \mathrm{p}$.

McKee, E. H., 1974, Northumberland caldera and Northumberland Tuff: Nevada Bur. Mines and Geology Rept. 19, p. 35-41.

Maher, J. C., Carter, R. D., Lantz, R. J., 1975, Petroleum geology of Naval Petroleum Reserve No. 1, Elk Hills, Kern County, California: U.S. Geol. Survey Prof. Paper $912,109 \mathrm{p}$.

Marie, J. R., 1975, Hydraulic characteristics and water-supply potential of the aquifers in the vicinity of the wastewater treatment plant, South Bend, Indiana: U.S. Geol. Survey Water-Resources Inv. WRI, 49-74, $26 \mathrm{p}$.

Marvin, R. F., Byers, F. M., Jr., Mehnert, H. H., Orkild, P. P., and Stern, T. W., 1970, Radiometric ages and stratigraphic sequence of volcanic and plutonic rocks, southern Nye and western Lincoln Counties, Nevada: Geol. Soc. America Bull., v. 81, no. 9, p. 2657-2676.

Miller, F. K., 1974a, Preliminary geologic map of the Newport Number 1 quadrangle, Pend Oreille County, Washington, and Bonner County, Idaho: Washington Div. Geology Earth Resources Geol. Map GM-7, 6 p. text.

$-1974 b$, Preliminary geologic map of the Newport Number 3 quadrangle, Pend Oreille, Stevens, and Spokane Counties, Washington: Washington Div. Geology 
Earth Resources Geol. Map GM-9, 7 p. text.

Miller, F. K., and Clark, L. D., 1975, Geology of the Chewelah-Loon Lake area, Stevens and Spokane Counties, Washington, with a section on Potassium-argon ages of the plutonic rocks, by J. C. Engles: U.S. Geol. Survey Prof. Paper 806, 74 p.

Morse, W. C., 1931, Pennsylvanian invertebrate fauna, in The paleontology of Kentucky: Kentucky Geol. Survey, ser. 6, v. 36, p. 293-348.

Nelson, A. E., 1975, Bedrock geologic map of the Natick quadrangle, Middlesex and Norfolk Counties, Massachusetts: U.S. Geol. Survey Geol. Quad. Map GQ-1208.

Oakes, M. H., 1966, North Cut Bank field and the Moulton sandstone, in Symposium, Jurassic and Cretaceous stratigraphic traps, Sweetgrass arch-Billings Geol. Soc. 17th Ann. Field Conf. 1966, Guidebook: Billings, Mont., Billings Geol. Soc., p. 191-201.

Oliver, W. A., Jr., Merriam, C. W., and Churkin, Michael, Jr., 1975, Ordovician, Silurian, and Devonian corals of Alaska: U.S. Geol. Survey Prof. Paper 823-B, p. B13-B44.

Orkild, P. P., and Jenkins, E. C., 1970, Report of exploration progress, Pahute Mesa, period January 31, 1968-October 1, 1969: U.S. Geol. Survey rept. USGS-474-70, 79 p. (Available only from Natl. Tech. Inf. Service, Springfield, Va. 22161.)

O'Sullivan, R. B., 1975, Coughs Creek Tongue-a new tongue of the Eocene Green River Formation, Piceance Creek basin, Colorado: U.S. Geol. Survey Bull. 1395-G, $7 \mathrm{p}$.

Parks, W. S., and Russell, E. E., 1975, Geologic map showing Upper Cretaceous, Paleocene, lower and middle Eocene units and distribution of younger fluvial deposits in western Tennessee: U.S. Geol. Survey Misc. Geol. Inv. Map I-916.

Peper, J. D., Pease, M. H., Jr., and Seiders, V. M., 1975, Stratigraphic and structural relationships of the Brimfield Group in northeast-central Connecticut and adjacent Massachusetts: U.S. Geol. Survey Bull. 1389, 31 p.

Perry, E. S., 1928, The Kevin-Sunburst and other oil and gas fields of the Sweetgrass arch: Montana Bur. Mines and Metallurgy Mem. 1, 41 p.

Peterson, Fred, and Barnum, B. E., 1973a, Geologic map and coal resources of the northeast quarter of the Cummings Mesa quadrangle, Kane Conty, Utah: U.S. Geol. Survey Coal Inv. Map C-63, 2 sheets.

$-1973 \mathrm{~b}$, Geologic map and coal resources of the northwest quarter of the Cummings Mesa quadrangle, Kane County, Utah: U.S. Geol. Survey Coal Inv. Map C-64, 2 sheets.

Péwé, T. L., 1975a, Quaternary geology of Alaska: U.S. Geol. Survey Prof. Paper 835, $145 \mathrm{p}$.

-1975b, Quaternary stratigraphic nomenclature in unglaciated central Alaska: U.S. Geol. Survey Prof. Paper 862, 32 p.

Pooser, W. K., 1965, Biostratigraphy of Cenozoic Ostracoda from South Carolina: Kansas Univ. Paleont. Contr. [38], Arthropoda, Art. 8, 80 p.

Prinz, W. C., 1967, Pre-Quaternary geologic and magnetic map and sections of part of the eastern Gogebic Iron Range, Michigan: U.S. Geol. Survey Misc. Geol. Inv. Map I-497.

Quinlivan, W. D., and Rogers, C. L., 1974, Geologic map of the Tybo quadrangle, Nye County, Nevada: U.S. Geol. Survey Misc. Geol. Inv. Map I-821.

Ratcliffe, N. M., 1974a, Bedrock geologic map of the State Line quadrangle, Columbia County, New York, and Berkshire County, Massachusetts: U.S. Geol. Survey Geol. Quad. Map GQ-1142.

- 1974b, Bedrock geologic map of the Stockbridge quadrangle, Berkshire County, Massachusetts: U.S. Geol. Survey Geol. Quad. Map GQ-1143.

Ratcliffe, N. M., and Harwood, D. S., 1975, Blastomylonites associated with recumbent folds and overthrusts in the western edge of the Berkshire massif, Connecticut and 
Massachusetts-A preliminary report: U.S. Geol. Survey Prof. Paper 888-A, 19 p. Reger, R. D., Péwé, T. L., Hadleigh-West, F., and Skarland, I., 1964, Geology and archeology of the Yardang flint station: Alaska Univ., Anthropol. Paper, v. 12, no. 2, p. 92-100.

Richards, P. W., 1955, Geology of the Bighorn Canyon-Hardin area, Montana and Wyoming: U.S. Geol. Survey Bull. 1026, 93 p.

Richter, D. H., and Dutro, J. T., Jr., 1975, Revision of the type Mankomen Formation (Pennsylvanian and Permian), Eagle Creek area, eastern Alaska Range, Alaska: U.S. Geol. Survey Bull. 1395-B, 25 p.

Rioux, R. L., Hite, R. J., Dyni, J. R., and Gere, W. C., 1975, Geologic map of the Upper Valley quadrangle, Caribou County, Idaho: U.S. Geol. Survey Geol. Quad. Map GQ-1194, 6-p. text.

Roberts, A. E., 1972, Cretaceous and early Tertiary depositional and tectonic history of the Livingston area, southwestern Montana: U.S. Geol. Survey Prof. Paper 526-C, $120 \mathrm{p}$.

Robinson, C. S., Mapel, W. J., and Bergendahl, M. H., 1964, Stratigraphy and structure of the northern and western flanks of the Black Hills uplift, Wyoming, Montana, and South Dakota: U.S. Geol. Survey Prof. Paper 404, 134 p.

Robison, R. A., 1960, Lower and Middle Cambrian stratigraphy of the eastern Great Basin, in Geology of east-central Nevada: Intermountain Assoc. Petroleum Geologists, 11th Ann. Field Conf., 1960 Guidebook, p. 43-52.

Ross, R. J., Jr., Jaanusson, Valdar, and Friedman, Irving, 1975, Lithology and origin of Middle Ordovician calcareous mudmound at Meiklejohn Peak, southern Nevada: U.S. Geol. Survey Prof. Paper 871, 48 p.

Roth, Robert, 1928, Correlation of a well core with outcrop sandstone [Carter County, Oklahoma]: Econ. Geology, v. 23, no. 1, p. 45-54.

Rowett, C. L., 1975, Stratigraphic distribution of Permian corals in Alaska: U.S. Geol. Survey Prof. Paper 823-D, p. D59-D75.

Ruppel, E. T., 1975, Precambrian Y sedimentary rocks in east-central Idaho: U.S. Geol. Survey Prof. Paper 889-A, 23 p.

Ruppel, E. T., Ross, R. J., Jr., and Schleicher, David, 1975, Precambrian Z and Lower Ordovician rocks in east-central Idaho: U.S. Geol. Survey Prof. Paper 889-B, p. $25-34$.

Russell, E. E., 1966, Geologic map of the Sardis quadrangle, Tennessee: Tennessee Div. Geology Geol. Map GM-12-NE (separate text).

Sandberg, C. A., 1975, McGowan Creek Formation, new name for Lower Mississippian flysch sequence in east-central Idaho: U.S. Geol. Survey Bull. 1405-E, 11 p.

Sando, W. J., and Dutro, J. T., Jr., 1974, Type sections of the Madison Group (Mississippian) and its subdivisions in Montana: U.S. Geol. Survey Prof. Paper 842, 22 p.

Sargent, K. A., Noble, D. C., and Ekren, E. B., 1965, Belted Range Tuff of Nye and Lincoln Counties, Nevada, in Cohee, G. V., and West, W. S., Changes in stratigraphic nomenclature by the U.S. Geological Survey 1964: U.S. Geol. Survey Bull. 1224-A, p. A32-A36.

Sargent, K. A., and Orkild, P. P., 1973, Geologic map of the Wheelbarrow PeakRainier Mesa area, Nye County, Nevada: U.S. Geol. Survey Misc. Geol. Inv. Map I-754.

Sartenaer, Paul, and Sandberg, C. A., 1974, New North American species of upper Famennian rhynchonellid genus Megalopterorhynchus from Lost River Range, Idaho: Jour. Paleontology, v. 48, no. 4, p. 756-765.

Schmidt, R. G., and Trent, V. A., 1969, Mafic dikes in the Precambrian rocks of Gogebic County, Michigan [abs.], in Inst. Lake Superior Geology, 15th Ann., 1969, Tech. Sess. Abs.: Oshkosh, Wis., Wisconsin State Univ., Dept. Geology, p. 31-33.

Schnabel, R. W., 1974, Bedrock geologic map of the Southwick quadrangle, Mass- 
achusetts and Connecticut: U.S. Geol. Survey Geol. Quad. Map GQ-1170.

Scholl, D. W., Marlow, M. S., and Buffington, E. C., 1975, Summit basins of the Aleutian Ridge, North Pacific: Am. Assoc. Petroleum Geologists Bull., v. 59, no. 5, p. $799-816$.

Schroeder, M. C., 1952, Geology of the Bead Lake district, Pend Oreille County, Washington: Washington Div. Mines and Geology Bull. 40, 57 p.

Scott, G. R., 1975, Reconnaissance geologic map of the Buena Vista quadrangle, Chaffee and Park Counties, Colorado: U.S. Geol. Survey Misc. Field Studies Map MF657.

Scott, G. R., and Taylor, R. B., 1975, Post-Paleocene Tertiary rocks and Quaternary volcanic ash of the Wet Mountain Valley, Colorado: U.S. Geol. Survey Prof. Paper $868,15 \mathrm{p}$.

Scott, G. R., Van Alstine, R. E., and Sharp, W. N., 1975, Geologic map of the Poncha Springs quadrangle, Chaffee County, Colorado: U.S. Geol. Survey Misc. Field Studies Map MF-658.

Seaman, W. A., Summary of the geology of the Marquette iron range, in Snelgrove, A. K., Seaman, W. A., and Ayres, V. L., 1944, Strategic minerals investigations, Marquette and Baraga Counties, 1943: Michigan Geol. Survey Prog. Rept. 10, p. 11-17.

Siple, G. E., Brown, P. M., and LeGrand, H. E., 1956, Stratigraphic significance of Foraminifera from an outcrop of the Tuscaloosa formation at Cheraw, South Carolina [abs.]: Geol. Soc. America Bull., v. 67, no. 12, pt. 2, p. 1757-1758.

Skipp, B. L., and Hall, W. E., 1975, Structure and Paleozoic stratigraphy of a complex of thrust plates in the Fish Creek Reservoir area, south-central Idaho: U.S. Geol. Survey Jour. Research, v. 3, no. 6, p. 671-689.

Skipp, B. L., and Sandberg, C. A., 1975, Silurian and Devonian miogeosynclinal and transitional rocks of the Fish Creek Reservoir window, central Idaho: U.S. Geol. Survey Jour. Research, v. 3, no. 6, p. 691-706.

Smith, J. F., Jr., and Ketner, K. B., 1975, Stratigraphy of Paleozoic rocks in the Carlin-Pinon Range area, Nevada: U.S. Geol. Survey Prof. Paper 867-A, 87 p.

Snavely, P. D., Jr., MacLeod, N. S., Rau, W. W., Addicott, W. O., and Pearl, J. E., 1975, Alsea Formation-an Oligocene marine sedimentary sequence in the Oregon Coast Range: U.S. Geol. Survey Bull. 1395-F, 21 p.

Speed, R. C., and McKee, E. H., 1974, Age and origin of the Darrough Felsite, Toiyabe Range, Nevada, in Geological Survey research 1974: U.S. Geol. Survey Prof. Paper 900 , p. 46.

Stephenson, L. W., 1907, Some facts relating to the Mesozoic deposits of the Coastal Plain of North Carolina: Johns Hopkins Univ. Circ., new ser., no. 7, p. 93-99.

1912, The Cretaceous formations, in Clark, W. B., and others, the Coastal Plain of North Carolina: North Carolina Geol. Econ. Survey, [Rept.], v. 3, p. 73-171.

Steven, T. A., Luedke, R. G., and Lipman, P. W., 1974, Relation of mineralization to calderas in the San Juan volcanic field southwestern Colorado: U.S. Geol. Survey Jour. Research, v. 2, no. 4, p. 405-409.

Stevenson, F. V., 1945, Devonian of New Mexico: Jour. Geology, v. 53, no. 4, p. 217245.

Stewart, D. B., and Wones, D. R., 1974, Bedrock geology of northern Penobscot Bay area, in New England Intercollegiate Geol. Conf., 66th Ann. Mtg., Oct. 12-13, 1974, Guidebook for field trips in east-central and north-central Maine: Orono, Me., Univ. Maine, p. 223-239.

Stewart, J. H., and Poole, F. G., 1975, Extension of the Cordilleran miogeosynclinal belt to the San Andreas fault, southern California: Geol. Soc. America Bull., v. 86, no. 2, p. 205-212.

Sutherland, P. K., 1963a, Description of selected Pennsylvanian measured sections, in 
Miller, J. P., Montgomery, Arthur, and Sutherland, P. K., Geology of part of the southern Sangre de Cristo Mountains, New Mexico: New Mexico Bur. Mines and Mineral Resources Mem. 11, p. 56-73.

-1963b, Paleozoic rocks, in Miller, J. P., Montgomery, Arthur, and Sutherland, P. K., Geology of part of the southern Sangre de Cristo Mountains, New Mexico: New Mexico Bur. Mines and Mineral Resources Mem. 11, p. 22-46.

Sutherland, P. K., and Harlow, F. H., 1973, Pennsylvanian brachiopods and biostratigraphy in southern Sangre de Cristo Mountains, New Mexico: New Mexico Bur. Mines and Mineral Resources Mem. 27, 173 p.

Swartz, F. M., 1948, Silurian relations at Susquehanna Gap in Blue or Kittatinny Mountains, 5 miles north of Harrisburg, Pennsylvania, [Pt. 2] of Pennsylvania Geol. Survey, 4th, 14th Annual Field Conference of Pennsylvania Geologists, Harrisburg, Pa., May 28-30, 1948: Harrisburg, Pa., 12 p.

Taliaferro, N. L., 1944, Cretaceous and Paleocene of Santa Lucia Range, California: Am. Assoc. Petroleum Geologists Bull., v. 28, no. 4, p. 449-521.

Tomlinson, C. W., 1928, Oil and gas geology of Carter County: Oklahoma Geol. Survey, Bull. $40-\mathrm{Z}, 78 \mathrm{p}$.

Toumey, Michael, 1848, Report on the geology of South Carolina: Columbia, S.C., A. S. Johnston, $293 \mathrm{p}$.

Trent, V. A., 1969, Geologic examination of pipeline trench through the east Gogebic Range, Michigan [abs.], in Inst. Lake Superior Geology, 15th Ann., 1969, Tech. Sess. Abs.: Oshkosh, Wis., Wisconsin State Univ., Dept. Geology, p. 37-38.

1972, Three-phase deformation associated with the Penokean orogeny, east Gogebic Range, Michigan [abs.]: Inst. Lake Superior Geology, 18th Ann., Houghton, Mich., 1972, Pt. 1, Tech. Sessions; Agenda and Abs., Paper 20, 4 p.

1973a, Geologic map of the Marenisco and Wakefield NE quadrangles, Gogebic County, Michigan: U.S. Geol. Survey open-file map, 4 sheets.

1973b, Surficial deposits of the Wakefield NE and Marenisco quadrangles, Gogebic County, Michigan: U.S. Geol. Survey open-file report, $10 \mathrm{p}$.

Tweto, O. L., 1974, Geologic map of the Holy Cross quadrangle, Eagle, Lake, Pitkin, and Summit Counties, Colorado: U.S. Geol. Survey Misc. Geol. Inv. Map I-830, 2 sheets.

Tyler, S. A., and Twenhofel, W. H., 1952, Sedimentation and stratigraphy of the Huronian of Upper Michigan-Pt. 2: Am. Jour. Sci., v. 250, no. 2, p. 118-151.

1973, Geological Survey research, 1973: U.S. Geol. Survey Prof. Paper 850, $366 \mathrm{p}$.

Van Hise, C. R., 1893, The Huronian Volcanics south of Lake Superior [abs.]: Geol. Soc. America Bull., v. 4, p. 435-436.

1896, Deformation of rocks, Pt. 4: Jour. Geology, v. 4, p. 593-629.

Wanless, H. R., 1946, Pennsylvanian geology of a part of the Southern Appalachian coal field: Geol. Soc. America Mem. 13, 162 p.

Waters, J. A., 1927, A group of Foraminifera from the Dornick Hills formation of the Ardmore Basin [Carter County, Oklahoma]: Jour. Paleontology, v. 1, no. 2, p. 129-133.

Watson, T. L., 1902, A preliminary report on a part of the granites and gneisses of Georgia: Georgia Geol. Survey Bull. 9-A, 367 p.

Webb, G. W., 1956, Middle Ordovician detailed stratigraphic sections for western Utah and eastern Nevada: Utah Geol. Mineralog. Survey Bull. 57, 77 p.

Wheeler, H. E., 1948, Late pre-Cambrian-Cambrian stratigraphic cross section through southern Nevada: Nevada Univ. Bull., Geol. and Min. Ser. 47, 58 p.

Wilpolt, R. H., and Marden, D. W., 1949, Upper Mississippian rocks of southwestern Virginia, southern West Virginia, and eastern Kentucky: U.S. Geol. Survey Oil and Gas Inv. Prelim. Chart 38, 3 sheets with text. 
1959, Geology and oil and gas possibilities of Upper Mississippian rocks of southwestern Virginia, southern West Virginia, and eastern Kentucky: U.S. Geol. Survey Bull. 1072-K, p. 587-656.

Wood, G. H., Jr., 1974, Geologic map of the Tamaqua quadrangle, Carbon and Schuylkill Counties, Pennsylvania: U.S. Geol. Survey Geol. Quad. Map GQ-1133. 

